\title{
Dolomitic slates from Uruguay: petrophysical and petromechanical characterization and deposit evaluation
}

\author{
Manuela Morales Demarco • Pedro Oyhantçabal • \\ Karl-Jochen Stein $\cdot$ Siegfried Siegesmund
}

Received: 22 March 2012/Accepted: 16 August 2012/Published online: 4 September 2012

(C) The Author(s) 2012. This article is published with open access at Springerlink.com

\begin{abstract}
Slates are internationally known as roof and façade-cladding material since prehistoric times. The methods required to mine and manufacture these dimensional stones are relatively simple in comparison to those utilized in granitic dimensional stones. This has led to a worldwide rentable commercialization of slate in the last centuries and also to the development of characteristic cultural landscapes. In Uruguay several slates are mined and used in architecture, especially as façade cladding and floor slabs. The most important slates regarding their production and utilization are the dolomitic slates. These dolomitic slates are associated with the Neoproterozoic thrust and fold belt of the Dom Feliciano belt. Representative samples have been geochemically and petrographically characterized, as well as petrophysically and petromechanically analyzed. The petrophysical and petromechanical properties were investigated in a very systematic way with respect to the new European standards, showing values comparable to those registered for internationally known slates. Detailed structural and deposit analysis were carried out in Uruguay in order to evaluate the dolomitic slate deposits. The slates are linked to calc-silicate strata in a greenschist facies volcano-sedimentary
\end{abstract}

M. Morales Demarco ( $\square) \cdot$ S. Siegesmund

Geoscience Center of the Georg-August University Göttingen,

Goldschmidtstrasse 7, 37077 Göttingen, Germany

e-mail: manugea@gmail.com

P. Oyhantçabal

Departamento de Geología, Facultad de Ciencias,

Universidad de la República, Iguá 4225,

C.P. 11400 Montevideo, Uruguay

K.-J. Stein

Natursteininformationsbüro, Am Schulzensee 3,

OT Waldsee, 17258 Feldberger Seenlandschaft, Germany sequence and the deposits are located in the limb of a regional fold, where bedding and cleavage are parallel. The main lithotype is a layered and fine-grained dolomitic slate with a quite diverse palette of colors: light and dark green, gray, dark gray, reddish and black. The mined slate is split into slabs $0.5-2 \mathrm{~cm}$ thick. In the past, the average production in Uruguay was around 4,000 tons/year and a historical maximum of 13,000 tons was reached in 1993 (Oyhantçabal et al. in Z dt Ges Geowiss 158(3):417-428, 2007). The oscillations in the regional demand were the cause of several flourishing and decay cycles in the activity, but our investigation shows a considerable volume of indicated resources and therefore a very good potential.

Keywords Slates - Dimensional stones - Petrophysical properties · Petrography $\cdot$ Uruguay

\section{Introduction}

Over the millennia slates in a broader sense have been one of the most favorite dimensional stones because of their particular attributes, such as fissility in a preferred direction and their high strength. Different shapes can be produced by simple technical means for roof and façade cladding (Fig. 1a), as well as for everyday objects and floor consolidation. Slate tablets and chalk (Fig. 1b) are one of the most important precursors to the personal computer, to which several generations owe their education in the acquisition of writing and mathematical skills.

Slate has been used as a roof-cladding material since Neolithic times (Card 2010). In regions where this resource was easily mined, the widespread application of slates in constructions resulted in the development of characteristic cultural landscapes. The traditional slate roof cladding has 


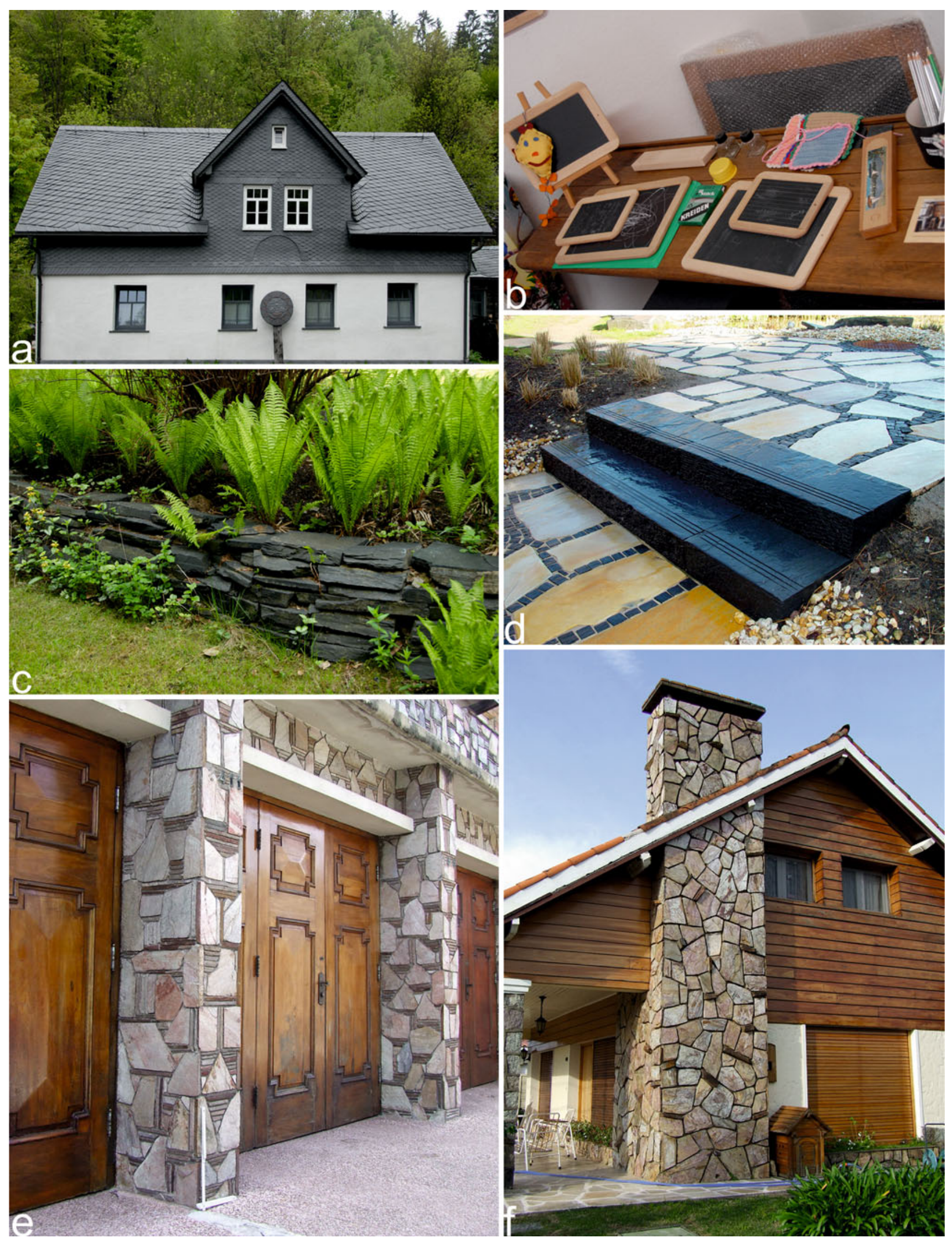


४ Fig. 1 Typical applications of slates in Uruguay and Germany. a Roof and wall cladding in Germany using traditional black slate; b slate tablets and blackboards for writing and drawing; c dry stone wall of black slate used for a fern bed (Germany); d polygonal floor slabs of Brazil colored slate and stair trades of black slate (Germany); e Uruguayan colored dolomitic slates used as wall cladding, note that the slabs are parallel and perpendicular to the slaty cleavage; f Uruguayan colored dolomitic slate applied as chimney cladding, socle cladding and polygonal floor slabs

been displaced by other building materials since middle of the twentieth century, leading to a dramatic decline of the traditional slate industry.

Some rock types (e.g., sandstones, gneisses) also show fissility and are often sold as slates because they are used in similar applications (floor slabs, wall cladding, etc.). The term slate defines a fine-grained metamorphic rock that underwent low-grade regional metamorphism and possesses slaty cleavage (Allaby and Allaby 1990; Jackson 1997; Bucher and Frey 2002). This cleavage is defined as a foliation, which results from the alignment of phyllosilicates in response to compressive tectonic deformation (Allaby and Allaby 1990; Jackson 1997; Bucher and Frey 2002). With respect to the DIN EN 12326-1, a slate is a metamorphic rock with slaty cleavage formed by the alignment of phyllosilicate minerals (mainly mica and chlorite), quartz and other typical minerals. From the commercial point of view, a slate is a dimensional stone with a very well-developed fissility, which allows the rock to be easily split. Afterwards the stone can be manufactured into roofing and cladding slate, or be used in special cases such as billiard table-tops, laboratory benches, and blackboards (Allaby and Allaby 1990).

Rocks possessing this property are slates, some gneisses and phyllites, some limestones, quartzites and fine-grained pyroclastic rocks. In contrast, fine-grained sedimentary rocks with a high proportion of clay minerals are defined as shale. When they are split into thin slabs they are also commercialized as slates.

When the rock splits along the original bedding the terms used are "mass slate" or "parallel slate" (from the German term "Parallelschiefer"). When the dominant fissility is defined by a new developed cleavage, the term "transversal slate" (from the German "Transversalschiefer") is preferred. The angle between the slaty cleavage and the bedding can vary and is essentially the result of the tectonic overprinting.

Prior to the application of new varieties, it is necessary to analyze the stone petrographically and conduct petrophysical investigations to ensure a safe use for construction purposes. In the slate group it is critical to evaluate the amount of ore minerals (pyrite, chalcopyrite, etc.) and carbonates. Also petromechanical properties are of particular relevance, especially flexural strength, as well as water uptake, thermal behavior and freeze-thaw stability.
Another factor to be taken into account prior to the application of new slate varieties is the reliability of the supply. This is related to the fact that some slates are only available for a short time and only in a few specific formats. Relying on established commercial varieties will possibly prevent constructional and technical delivery problems.

In addition to the geology of the deposit, the durability of the slate plays a decisive role in their possible applications. The expected economic lifetime of roof and façade-cladding slate depends on the resistance against environmental agents, especially weather conditions to which they are exposed. These include salt attack or freeze-thaw stability as well as impacts of thermal and hydric variations. Slates with inclusions, e.g., coarse-grained pyrite, are not very stable against temperature changes, due to the difference in thermal expansion among the rock components. This differential behavior can lead to a loosening of these inclusions from slates used for different constructive purposes. Chemical and biological weathering can be critical for different types of slates, especially when considering the relevance of color stability.

In this study, the Uruguayan slates are characterized in detail based on their petrography and petrophysical properties. In order to perform a comparison several slates from Spain, Brazil, Argentina, Portugal and Germany are also characterized from the petrographical and petrophysical point of view. Three groups of slates have been defined: dolomitic, semipelitic and pelitic slates.

\section{Overview of the slate market and slate applications}

According to Montani (2008), the main producers of slate in 2007 were, in order of importance, Spain, Brazil, China, Canada and India (Fig. 2); together these countries produce almost $75 \%$ of the world production. Other countries supplying slate as a dimensional stone are Italy, the USA, Germany, Belgium, Norway, France, Portugal and Turkey. The most important consumer is France. Traditional slate countries in terms of use are also Germany, Benelux and Great Britain. Uruguay has a relatively large variety of slates, which are incorrectly described as quartzites (Comunità Economica Europea-Uruguay, no date) or chloritic phyllites (Coronel et al. 1987).

A highly appreciated feature typical of slates is their uniform fabric and, in most of the cases, a deep black color. Their schistose structure is advantageous and convenient for mining and processing. Traditionally slates have been used as roof and façade-cladding material. The optimization of modern mining techniques allows the excavation of larger blocks and better processing. This has led to a greater spectrum of products, and therefore, a wider application of slates.

For the design of outdoor areas the new application for slates includes floor slabs (in various polygonal shapes), 


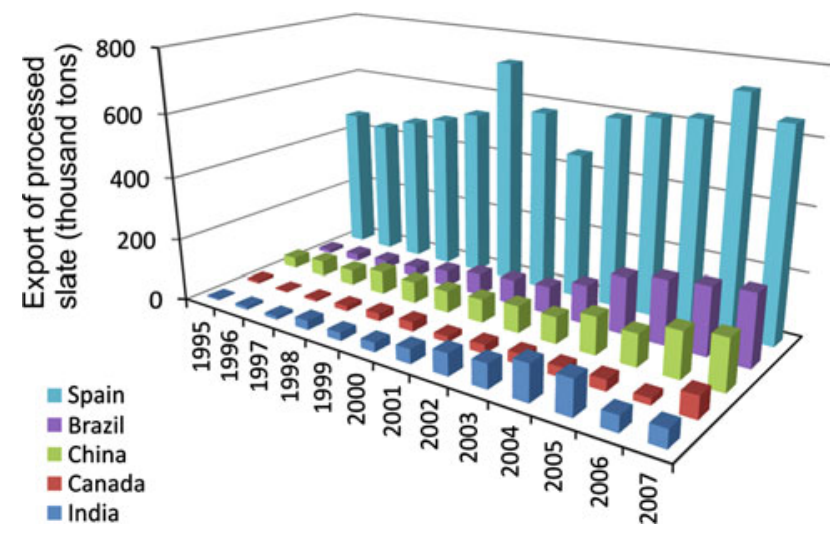

Fig. 2 Export of processed slate from the main producing countries between 1995 and 2007 (data after Montani 2008)

garden and landscaping elements (Fig. 1c), stone stair treads (Fig. 1d), gabions, stream and spring cladding, rubble stone and dry stone walls. Even gravestones and tombs are constructed using slate.

For indoor use several examples include pavements (in various polygonal shapes), wall cladding, window sills, marquetry elements for tables and furniture, as well as gift items (watches, platters, etc.). The spectrum of products also includes antibacterial washbasins and kitchen countertops with smooth, polished or rough surfaces. The use of slates for roof and façade-cladding material has not lost its architectural importance. For this reason standards and quality criterions have been defined for roof and façadecladding slates in several economic regions (EU, USA, etc.). The quality criteria defined by these standards are matched by the traditional slate deposit (e.g., Mosel slate, Thüringer slate, Spanish slates, English slates), as well as by some of the new slate deposits (e.g., Chinese slates).

Traditional local use of fissile rocks in the areas of their exploitation is still common today, e.g., Gneiss in Switzerland and the "Alta Quartzite" in northern Norway. Since the middle of the twentieth century, slates from Uruguay have been utilized in the whole country for wall cladding and floor tiles (Fig. 1e, f).

\section{Geological setting of Uruguayan slates}

The Precambrian basement of Uruguay is represented, from west to east, by the Río de la Plata Craton (Almeida 1971; Oyhantçabal et al. 2011), the Nico Pérez Terrane (Bossi and Ferrando 2001; Oyhantçabal et al. 2011), the Dom Feliciano Belt (Fragoso César 1980), the Punta del Este Terrane (Preciozzi et al. 1999) and the Rocha Group (Fig. 3). The Río de la Plata Craton (RPC) in Uruguay corresponds to the Piedra Alta Terrane, which includes metavulcanosedimentary belts and a central granitic-gneissic complex of Paleoproterozoic age (Bossi and Ferrando 2001; Oyhantçabal et al. 2011).
The Nico Pérez Terrane (NPT), which was originally defined as part of the RPC (Bossi and Campal 1992), was recently excluded from the craton by Oyhantçabal et al. (2011) on the basis of differences in the tectono-stratigraphic evolution of both units. The NPT is bounded to the west by the RPC through the Sarandí del Yí Shear Zone (SYSZ) and to the east and southeast by the Dom Feliciano Belt (DFB) (Fig. 3).

The DFB is the result of the collision of the Río de la Plata, Congo and Kalahari cratons that took place during the Late Neoproterozoic (Brasiliano Cycle) (Porada 1989). This collision led to the amalgamation of West Gondwana (Brito Neves and Cordani 1991). The DFB comprises a granite, schist and foreland belt that extends from southernmost Uruguay to southern Brazil (Rio Grande do Sul and Santa Catarina states) (Basei et al. 2000). The Lavalleja Group (Bossi et al. 1965; Sánchez Bettucci 1998) represents the schist belt in Uruguay (Basei et al. 2008).

Especially relevant for the present work is the Lavalleja Group (LG), since here are located the dolomitic slate deposits. This unit was first defined by Bossi et al. (1965), being further studied by Midot (1984), Sánchez Bettucci (1998), Sánchez Bettucci and Ramos (1999) and Oyhantçabal et al. (2001). All these authors agree that the LG is composed of metavolcanic and metasedimentary sequences that underwent metamorphism under greenschist to lower amphibolite facies conditions. This group crops out to the north of Pan de Azúcar city to $70 \mathrm{~km}$ northwest of Treinta y Tres city, and between SYSZ and Sierra de Ánimas Complex (to the west) and Carapé Complex (to the east) (Fig. 3).

In the southern region the LG was further subdivided by Midot (1984), Sánchez Bettucci (1998) and Oyhantçabal et al. (2001). The first author defines the Minas and Fuente del Puma Series, while the second author, recategorized these units as formations and added a third one: the Zanja del Tigre Formation. Oyhantçabal et al. (2001) proposed a different approach, subdividing the LG into four lithological associations. These associations are, from west to east: La Plata (LPA), Peña Blanca (PBA), Minas Viejas (MVA) and Zanja del Tigre-Cuchilla Alvariza (ZTCAA).

The lithologies of the current investigation belong to the Fuente del Puma Formation (Midot 1984; Sánchez Bettucci 1998) or to the lithological association Minas Viejas (Oyhantçabal et al. 2001). The preferred classification used in this study is the one defined by Oyhantçabal et al. (2001), since it presents a more detailed analysis in the considered area. The MVA is where the dolomitic slate deposits are exposed. The northwestern boundary of this association with the PBA is the Peña Blanca Lineament, which also acts as a boundary with the LPA to the south. The Mina Oriental Lineament is the boundary of the MVA with the ZTCAA (to the east) and with the Carapé 
Fig. 3 Geological map of southeastern Uruguay. The location of the dolomitic slates mining district is indicated (redrawn after Oyhantçabal et al. 2010 and Sánchez Bettucci et al. 2010)

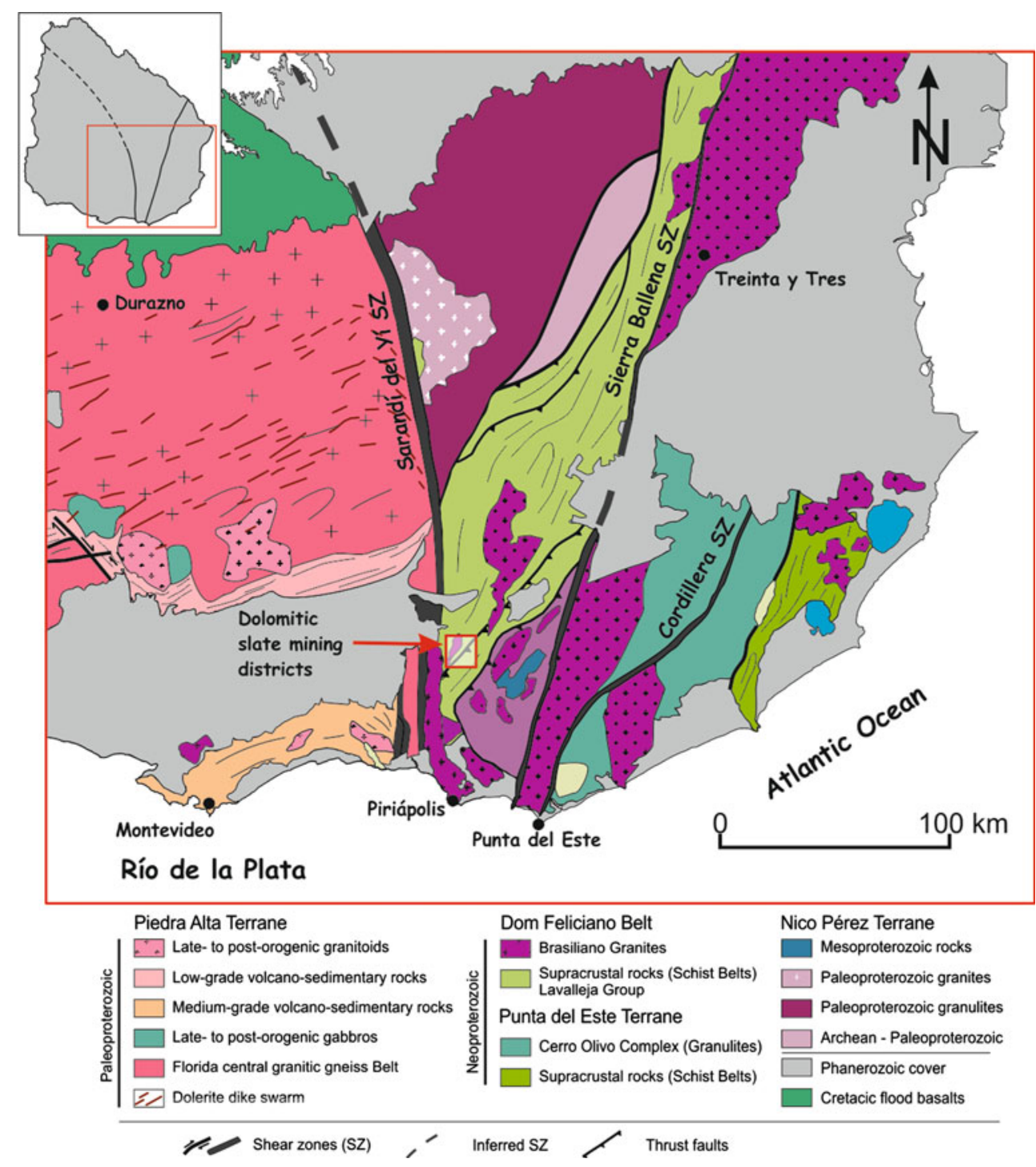

Granitic-Gneissic Complex, the syn-tectonic Brasiliano granites and a pre-Brasiliano basement (to the north).

The MVA, as originally defined, is composed of calcareous phyllites, basic metavolcanics, limestones, and metapelites. Geomorphologically, this association forms NNE elongated hills in the south central region, with very steep slopes and associated V-shaped valleys. While in the north the hills show less pronounced slopes and the valleys are narrow and flat bottom-shaped (Oyhantçabal et al. 2001). These authors considered that the calcareous phyllites are the predominant lithological type. They form outcrops of elongated ridges kilometers in scale and always in the upper topographic positions. An excellent layering defines these exposures, determined by alternating carbonate and phyllosilicate layers and a well-developed cleavage.
These structural features correspond to a regional transpressional tectonic regime and are defined by strikeslip faults, thrust faults and megafolds observable in aerial and satellite images. Further details to the structural features observed in the studied lithologies are described in the deposit characterization subchapter.

\section{Lithological inventory}

The main slate quarries active in Uruguay today were sampled for geochemical and petrographic analysis. In order to identify the factors leading to a commercially viable stone, other locations were sampled where mining was unsuccessful. Several internationally known slates were also analyzed as a reference for comparison (e.g., the 
Table 1 List of investigated slates

\begin{tabular}{|c|c|c|c|}
\hline Trade name & Sample & Lithology & Company/location \\
\hline Piedra laja negra & U33 & Slaty dolomitic semipelite & Caorsi Hnos, Arroyo Mataojo, Lavalleja \\
\hline Piedra laja negra & U45 & Slaty dolomitic semipelite & Rufo Hnos, Arroyo Mataojo, Lavalleja \\
\hline Piedra laja ocre & U38A & Slaty dolomitic semipelite & Carmine Rufo, Arroyo Minas Viejas, Lavalleja \\
\hline Piedra laja gris plomo & U38B & Slaty dolomitic semipelite & Carmine Rufo, Arroyo Minas Viejas, Lavalleja \\
\hline Piedra laja verde oscura & $\mathrm{U} 38 \mathrm{C}$ & Slaty dolomitic metacarbonate rock & Carmine Rufo, Arroyo Minas Viejas, Lavalleja \\
\hline Piedra laja verde clara & U38D & Slaty dolomitic metacarbonate rock & Carmine Rufo, Arroyo Minas Viejas, Lavalleja \\
\hline Piedra laja verde clara "macho" & U38M & Slaty dolomitic metacarbonate rock & Carmine Rufo, Arroyo Minas Viejas, Lavalleja \\
\hline Piedra laja gris plomo & UY-19 & Slaty dolomitic metacarbonate rock & Francesco Carinci, Arroyo Minas Viejas, Lavalleja \\
\hline Piedra laja ocre & UY-21 & Slaty dolomitic metacarbonate rock & Francesco Carinci, Arroyo Minas Viejas, Lavalleja \\
\hline Green carbonatic slate with $S_{2}$ & UY-45 & Slaty dolomitic semipelite & Francesco Carinci, Arroyo Minas Viejas, Lavalleja \\
\hline Piedra laja ocre & UY-54 & Slaty dolomitic semipelite & Carmine Rufo, Arroyo Minas Viejas, Lavalleja \\
\hline Piedra laja gris y negra & UY-85 & Slaty dolomitic psammite & Arroyo Mataojo, south of Rute 81, Maldonado \\
\hline Green carbonatic folded slate & UY-87 & Slaty dolomitic metacarbonate rock & Carmine Rufo, Arroyo Minas Viejas, Lavalleja \\
\hline Green carbonatic slate with $S_{2}$ & UY-88 & Slaty dolomitic semipelite & Carmine Rufo, Arroyo Minas Viejas, Lavalleja \\
\hline Piedra laja verde oscura & UY-90 & Slaty dolomitic metacarbonate rock & Carmine Rufo, Arroyo Minas Viejas, Lavalleja \\
\hline Piedra laja rosada con gris & UY-106 & Slaty dolomitic pelite & Rufo Hnos, Road School 90, Lavalleja \\
\hline Piedra laja Rocha & UY-108 & Slaty muscovitic pelite & Puntas del Chafalote, Rocha \\
\hline Ardósia Apiúna & AP & Slaty muscovitic pelite & Apiúna, Santa Catarina, Brazil \\
\hline Ardósia Gaspar & GA & Slaty muscovitic pelite & Gaspar, Santa Catarina, Brazil \\
\hline Piedra Laja San Luís & $\mathrm{AR}$ & Slaty muscovitic pelite & El Trapiche, San Luís, Argentina \\
\hline Ardósia de Canelas & PL & Slaty muscovitic pelite & Arouca, Aveiro, Portugal \\
\hline Sauerland Schiefer & WS & Slaty muscovitic pelite & Sauerland, Germany \\
\hline Pizarra de techar & 120 & Slaty muscovitic pelite & La Fraguiña, Carballeda de Valdeorras, Galicia, Spain \\
\hline Pizarra de techar & 150 & Slaty muscovitic pelite & Valdemiguel, Carballeda de Valdeorras, Galicia, Spain \\
\hline Xisto negro de Foz Côa & $\mathrm{PO}$ & Slaty muscovitic semipelite & Vila Nova de Foz Côa, Guarda, Portugal \\
\hline Lotharheil Schiefer & LO & Slaty muscovitic semipelite & Lotharheil, Geroldsgrün, Germany \\
\hline Theuma Fruchtschiefer & $\mathrm{TH}$ & Slaty muscovitic pelite & Vogtland, Sachsen, Germany \\
\hline
\end{tabular}

Spanish roofing slates). All the rocks investigated are listed in Table 1 with their corresponding lithology, location and sample abbreviation.

\section{Geochemistry}

The geochemistry of the slates was determined by X-ray fluorescence (XRF). The results are given in Tables 10, 11 (Appendix). The major components of the slates are $\mathrm{SiO}_{2}$, $\mathrm{Al}_{2} \mathrm{O}_{3}, \mathrm{Fe}_{2} \mathrm{O}_{3 \mathrm{t}}, \mathrm{MgO}, \mathrm{CaO}, \mathrm{Na}_{2} \mathrm{O}, \mathrm{K}_{2} \mathrm{O}$ and $\mathrm{CO}_{2}$.

The $\mathrm{SiO}_{2}$ content varies from $29.15 \mathrm{wt} \%$ in the redgreen variety (UY-21) to $66.9 \mathrm{wt} \%$ in Vila Nova de Foz Côa (PO). The Uruguayan varieties that show higher contents of $\mathrm{SiO}_{2}$ are Piedra laja rosada con gris (UY-106) and Piedra laja Puntas del Chafalote (UY-108), with 56.27 and $60.92 \mathrm{wt} \%$, respectively.

$\mathrm{Al}_{2} \mathrm{O}_{3}$ shows a similar distribution, although is present in a lower proportion: between $6.07 \mathrm{wt} \%$ in Piedra laja verde oscura (U38C) and $24.49 \mathrm{wt} \%$ in Ardósia de Canelas (PL). The proportion of $\mathrm{Al}_{2} \mathrm{O}_{3}$ is higher for the
Uruguayan varieties UY-106 and UY-108 than the other 15 Uruguayan samples. The highest $\mathrm{Al}_{2} \mathrm{O}_{3}$ values were analyzed for the samples of other countries (e.g., Argentina, Spain; Table 10).

The $\mathrm{Fe}_{2} \mathrm{O}_{3 \mathrm{t}}$ content shows a similar trend, varying from $1.90 \mathrm{wt} \%$ in Piedra laja verde clara (U38D) to $10.21 \mathrm{wt} \%$ in Ardósia de Canelas (PL). In the Uruguayan varieties the higher values of $\mathrm{Fe}_{2} \mathrm{O}_{3 \mathrm{t}}$ are found in UY-106 and UY-108, with 6.52 and $4.78 \mathrm{wt} \%$, respectively. Note that all the $\mathrm{Fe}$ present is shown as $\mathrm{Fe}_{2} \mathrm{O}_{3 \mathrm{t}}$, not discriminated from $\mathrm{FeO}$.

The $\mathrm{MgO}, \mathrm{CaO}$ and $\mathrm{CO}_{2}$ contents show a clear relationship, so that the samples with higher contents of $\mathrm{MgO}$ and $\mathrm{CaO}$ also show the higher content of $\mathrm{CO}_{2}$. This is due to the fact that these three oxides combine with $\mathrm{CO}_{2}$ to form carbonates. Ardósia Gaspar (GA) shows the lowest $\mathrm{CO}_{2}$ content. The highest contents of $\mathrm{MgO}$ are observed in the variety Piedra laja gris plomo (UY-19) with $12.84 \mathrm{wt} \%$, and in general, for all Uruguayan slates analyzed with the exception of UY-108.

Another negative correlation is observed between the carbonate-forming oxides and $\mathrm{SiO}_{2}$ as well as $\mathrm{Al}_{2} \mathrm{O}_{3} \cdot \mathrm{Na}_{2} \mathrm{O}$ 
Table 2 Total carbon $\left(\mathrm{C}_{\mathrm{tot}}\right)$, total organic carbon $\left(\mathrm{C}_{\mathrm{org}}\right)$, total carbonatic carbon $\left(\mathrm{C}_{\text {carb }}\right)$, total nitrogen $\left(\mathrm{N}_{\text {tot }}\right)$ and total sulfur $\left(\mathrm{S}_{\text {tot }}\right)$

\begin{tabular}{|c|c|c|c|c|c|c|c|c|}
\hline Sample & $\mathrm{C}_{\text {tot }}$ & $\mathrm{C}_{\text {org }}$ & $\mathrm{C}_{\text {carb }}$ & $\mathrm{CaCO}_{3}$ & $\mathrm{~N}_{\text {tot }}$ & $\mathrm{S}_{\text {tot }}$ & $\mathrm{C}_{\text {org } / \mathrm{N}}$ & $\mathrm{C}_{\text {org } / \mathrm{S}}$ \\
\hline U33 & 4.66 & 0.18 & 4.48 & 37.3 & 0.020 & 0.116 & 9.0 & 1.6 \\
\hline U45 & 3.40 & 0.12 & 3.28 & 27.3 & 0.017 & 0.022 & 7.1 & 5.5 \\
\hline U38A & 6.18 & 0.10 & 6.08 & 50.7 & 0.011 & 0.003 & 9.1 & 33.3 \\
\hline U38B & 4.99 & 0.11 & 4.88 & 40.7 & 0.012 & 0.002 & 9.2 & 55.0 \\
\hline U38C & 7.29 & 0.12 & 7.17 & 59.7 & 0.013 & 0.003 & 9.2 & 40.0 \\
\hline U38D & 7.34 & 0.12 & 7.22 & 60.2 & 0.013 & 0.022 & 9.2 & 5.5 \\
\hline $\mathrm{U} 38 \mathrm{M}$ & 6.97 & 0.11 & 6.86 & 57.2 & 0.013 & 0.098 & 8.5 & 1.1 \\
\hline $\mathrm{AP}$ & 0.87 & 0.16 & 0.71 & 5.9 & 0.034 & 0.006 & 4.7 & 26.7 \\
\hline GA & 0.14 & 0.13 & 0.01 & 0.1 & 0.042 & 0.006 & 3.1 & 21.7 \\
\hline $\mathrm{AR}$ & 0.12 & 0.11 & 0.01 & 0.1 & 0.019 & 0.070 & 5.8 & 1.6 \\
\hline PL & 0.40 & 0.39 & 0.01 & 0.1 & 0.079 & 0.233 & 4.9 & 1.7 \\
\hline WS & 0.74 & 0.51 & 0.23 & 1.9 & 0.083 & 0.300 & 6.1 & 1.7 \\
\hline 120 & 0.41 & 0.38 & 0.03 & 0.2 & 0.053 & 0.070 & 7.2 & 5.4 \\
\hline 150 & 0.44 & 0.42 & 0.02 & 0.2 & 0.057 & 0.076 & 7.4 & 5.5 \\
\hline $\mathrm{PO}$ & 0.21 & 0.20 & 0.01 & 0.1 & 0.035 & 0.111 & 5.7 & 1.8 \\
\hline LO & 0.80 & 0.15 & 0.65 & 5.4 & 0.032 & 0.043 & 4.7 & 3.5 \\
\hline $\mathrm{TH}$ & $0.00 *$ & $0.00 *$ & $0.00 *$ & $0.0^{*}$ & n.d. & $0.0^{*}$ & n.d. & $0.0 *$ \\
\hline
\end{tabular}

* Data after Fischer et al. (2011)

varies from less than $0.01 \mathrm{wt} \%$ in almost all Uruguayan slates to $2.52 \mathrm{wt} \%$ in Xisto negro de Foz Côa (PO). $\mathrm{K}_{2} \mathrm{O}$ values range from $1.83 \mathrm{wt} \%$ in Piedra laja verde clara $y$ oscura "macho" (UY-19) to $4.64 \mathrm{wt} \%$ in UY-108.

\section{Organic carbon}

Knowing the organic carbon content is essential when relating it with some of the rock properties, such as the color and the antibacterial properties. The total carbon $\left(\mathrm{C}_{\mathrm{tot}}\right)$ in the analyzed slates varies from $0.00 \mathrm{wt} \%$ in the Theuma Fruchtschiefer (TH) (Fischer et al. 2011) to $7.34 \mathrm{wt} \%$ in the Piedra laja verde clara (U38D) (Table 2). Dolomitic slates show a higher proportion of $\mathrm{C}_{\mathrm{tot}}$ in all the samples analyzed, with the proportion varying between $3.40 \mathrm{wt} \%$ in Piedra laja negra Rufo Hnos (U45) and $7.34 \mathrm{wt} \%$ in the already mentioned U38D. The pelitic and semipelitic slates contain $\mathrm{C}_{\text {tot }}$ values up to $0.87 \mathrm{wt} \%$, as in the case of Ardósia Apiúna (AP).

Considering how much of the carbon present is actually organic carbon is important because of the antimicrobial properties of the organic compounds, especially of the sulfonated shale oils (Listemann et al. 1993; Fluhr et al. 1998; Gayko et al. 2000). Organic carbon $\left(\mathrm{C}_{\text {org }}\right)$ contents are very low in all the samples analyzed; between $0.00 \mathrm{wt} \%$ in TH (Fischer et al. 2011) and $0.51 \mathrm{wt} \%$ in the Sauerland Schiefer (WS). The $\mathrm{C}_{\text {org }}$ content in the dolomitic slates ranges from 0.10 to $0.18 \mathrm{wt} \%$ and represents between 1.6 and $3.8 \%$ of the $\mathrm{C}_{\text {tot }}$ present.
Pelitic and semipelitic slates show a $\mathrm{C}_{\text {org }}$ content between 0.11 and $0.51 \mathrm{wt} \%$ of the whole sample, being markedly higher for some samples in comparison to the dolomitic slate group. The proportion of $\mathrm{C}_{\mathrm{org}}$ in the $\mathrm{C}_{\mathrm{tot}}$ is very high and ranges between 18.8 and $95.5 \mathrm{wt} \%$ in the pelitic and semipelitic slates (Table 2).

\section{Petrography}

The petrography of the investigated slates show a wide variation (in mineralogy, fabric, etc.), especially when comparing the dolomitic slates to the pelitic and semipelitic slates. The main difference is the occurrence of carbonate minerals, which are present in very high proportions in the first group, and are practically absent in the other two groups.

Determining mineral compositions in fine-grained metasedimentary rocks is often difficult by conventional optical microscopy, and thus alternative approaches were applied. The software Slatenorm (Prof. Dr. Dieter Jung, p.c.) and the X-ray diffraction Rietveld method were used to quantify the mineralogical composition (Tables 3, 12).

The first method calculates the normative minerals using the geochemistry, while the second performs a quantitative phase analysis using the XRD results. A strong correlation exists between both methods on the amounts of quartz. However, in the case of the phyllosilicates the correlation is not so obvious because of the uncertainty concerning the composition of these minerals (Ward and Gómez 
Table 3 X-ray diffraction result for the Uruguayan dolomitic slates

\begin{tabular}{|c|c|c|c|c|c|c|c|c|c|c|}
\hline Sample & Dolomite & Calcite & Quartz & Albite & Muscovite & Illite & Chlorite & Pyrite & Rutile & Hematite \\
\hline U33 & 36.5 & \multirow[t]{7}{*}{0.9} & 28.4 & \multirow{7}{*}{8.4} & 11.4 & 15.6 & 6.7 & & 0.5 & \multirow{7}{*}{0.6} \\
\hline U45 & 24.5 & & 32.9 & & 24.6 & & 9.6 & & & \\
\hline U38A & 49.2 & & 26.6 & & 11.2 & 11.0 & 2.1 & & & \\
\hline U38B & 40.3 & & 29.9 & & 13.4 & 12.1 & 3.2 & 0.2 & 0.3 & \\
\hline $\mathrm{U} 38 \mathrm{C}$ & 55.8 & & 21.9 & & 13.7 & 2.4 & 6.0 & & 0.3 & \\
\hline U38D & 58.5 & & 21.8 & & 10.4 & 5.9 & 3.3 & 0.2 & & \\
\hline U38M & 55.8 & & 22.9 & & 7.1 & 9.4 & 4.6 & 0.3 & & \\
\hline
\end{tabular}

Fernández 2003). In the dolomitic slates, the values for these phyllosilicates obtained by both methods are similar when illite coexists with muscovite. However, for the rest of the slates studied such a simple correlation does not exist; the chlorite contents are higher using the Rietveld method. Dolomite contents are similar when using both methods.

The normative mineralogical composition obtained has been used to classify the slates with respect to the nomenclature of the British Geological Survey (Robertson 1999). Following this classification schema, three different categories are used based on the quartz, feldspar, phyllosilicate and carbonate mineral contents.

The first category is for rocks containing mostly quartz, feldspar and mica. A second category is for rocks that have between 10 and $50 \%$ carbonate and/or calc-silicate minerals and at least $50 \%$ quartz + feldspar + mica. A third category uses another ternary diagram for the classification of rocks containing more than $50 \%$ calc-silicate and/or carbonate minerals (see Fig. 4). Textural and mineralogical qualifiers (e.g., slaty, dolomitic) are used to present more information on the classification of these rocks (see Robertson 1999). For all the rocks studied, the qualifier "slaty" will be used because all of them show a slaty cleavage that determines their strong fissility.

Uruguay has a relatively large variety of slates, which are incorrectly described as quartzites (Comunità Economica Europea-Uruguay, no date) or chloritic phyllites (Coronel et al. 1987). Most of the Uruguayan rocks analyzed contain dolomite as the main carbonate mineral, and the qualifier "dolomitic" is used instead of the word "calcareous".

The investigated slates (Table 1) were classified into five subgroups using the schema of Robertson (1999) and their normative mineralogy (Table 12 in Appendix and Fig. 4). These groups are: (1) slaty semipelites, e.g., Xisto negro de Foz Côa (PO) and Lotharheil Schiefer (LO) (Fig. 4a); (2) slaty pelites, includes the majority of the investigated rocks, as well as the Piedra laja Puntas del Chafalote (UY-108) (Fig. 4a); (3) slaty dolomitic metacarbonate rocks, comprising the following commercial varieties: Piedra laja verde oscura (U38C), Piedra laja verde clara (U38D) and Piedra laja verde clara "macho" (U38M) (Fig. 4b); (4) slaty dolomitic semipelites, e.g., Piedra laja ocre (U38A), Piedra laja negra Caorsi Hnos (U33) and Piedra laja gris y negra (UY-85) (Fig. 4b). Note that the last variety occurs at the border between the calcareous semipelites and calcareous psammite, due to its higher content of quartz and feldspar; and finally (5) the slaty dolomitic pelites, composed of only one variety, Piedra laja rosada con gris (UY-106) (Fig. 4b).

For simplicity the five subgroups mentioned above will be categorized into three main groups. Dolomitic slates are those rocks that classify as slaty dolomitic metacarbonate rocks, slaty dolomitic semipelite or slaty dolomitic pelite; as pelitic slates, rocks that group as slaty pelites; and as semipelitic slates are those designated as slaty semipelite.

\section{Dolomitic slates}

The dolomitic slates are composed mainly of dolomite, quartz and phyllosilicates (muscovite, illite and chlorite) (Table 12; Figs. 4b, 5). The normative amount of dolomite varies between $11.86 \mathrm{wt} \%$ in the Piedra laja rosada y gris (UY-106) and $57.92 \mathrm{wt} \%$ in the Piedra laja verde clara (UY-90). The grain size ranges from 0.04 to $0.18 \mathrm{~mm}$. Grains are generally anhedral and very difficult to discern as individual grains (Fig. 5). The black slates show a lower normative dolomite content, between 23.39 and $32.97 \mathrm{wt} \%$. Calcite is present in a low normative proportion, ranging from 0 to $4.12 \mathrm{wt} \%$, and normative siderite is present in only two samples at very small amounts, between 0.08 and $0.16 \mathrm{wt} \%$.

Quartz is the second most important mineral, as its normative abundance comprises between $19.64 \mathrm{wt} \%$ in the Piedra laja ocre (U38A) and 36.01 wt\% in the Piedra laja rosada con gris (UY-106). It occurs as anhedral grains with sizes that generally range from 0.05 to $0.12 \mathrm{~mm}$. In the black slates grain sizes can reach up to $0.30 \mathrm{~mm}$, and sometimes up to $1.10 \mathrm{~mm}$ as in some psammitic layers of the Piedra laja negra Caorsi Hnos (U33) (Fig. 5a). The 
Fig. 4 Classification of the investigated slates based on the normative composition of their sedimentary protolith (after Robertson 1999). a Pelitic and semipelitic slates and b dolomitic slates (mica* includes all the minerals not considered in the other vertices)

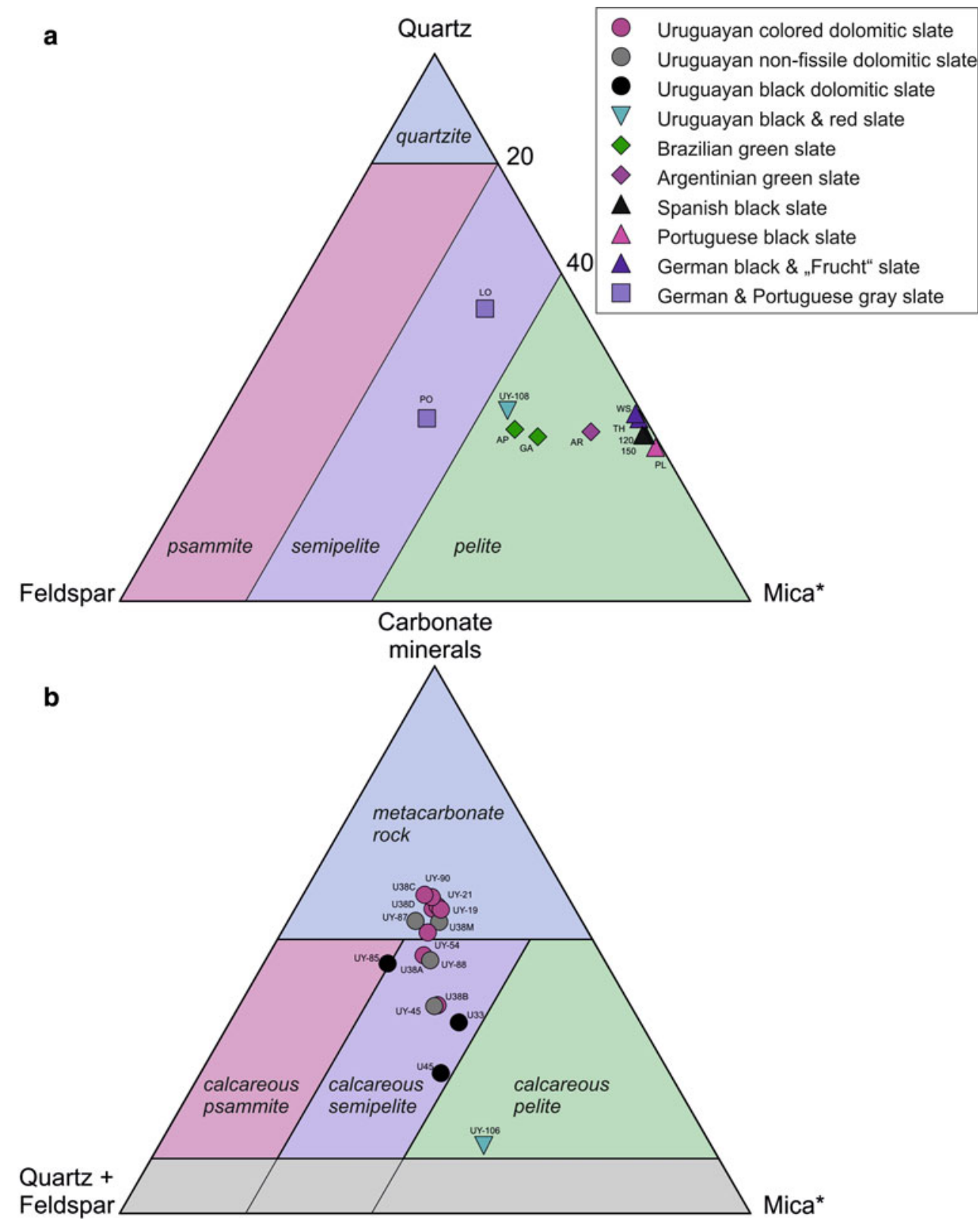

quartz grains are normally elongated parallel to the foliation with an aspect ratio between 1.5 and 4 . In the black variety of Rufo Hnos (U45) thin layers of about one centimeter, containing up to $50 \%$ medium-grained $(0.30 \mathrm{~mm})$ quartz grains, have been recognized (Fig. 5b). Quartz sometimes appears recrystallized or with undulose extinction.

Phyllosilicates form the third most important mineral component in these rocks. In thin section determining which phyllosilicate is present is difficult due to the very fine grain size. The most recognizable is muscovite. This mineral is one of the main normative phyllosilicates calculated using the program Slatenorm, as it comprises between 14.59 wt\% in the Piedra laja negra con gris (UY-
85 ) and $31.82 \mathrm{wt} \%$ in the Piedra laja rosada con gris (UY106).

However, in the majority of the dolomitic slates, the normative muscovite content is not higher than $24.07 \mathrm{wt} \%$ (Piedra laja negra, Caorsi Hnos). Muscovite appears as subhedral crystals of around $30-150 \mu \mathrm{m}$ in size with an aspect ratio of 4-12. Normative paragonite, a sodium-rich mica, is only present in the Piedra laja negra Rufo Hnos and when these two micas coexist, they represent $24.41 \mathrm{wt} \%$ of the rock. Therefore, the black dolomitic slates contain the greater proportion of mica minerals. Only some of the dolomitic slates studied show normative chlorite. This mineral has been recognized in hand specimens due to its typical green color, as well as in thin 

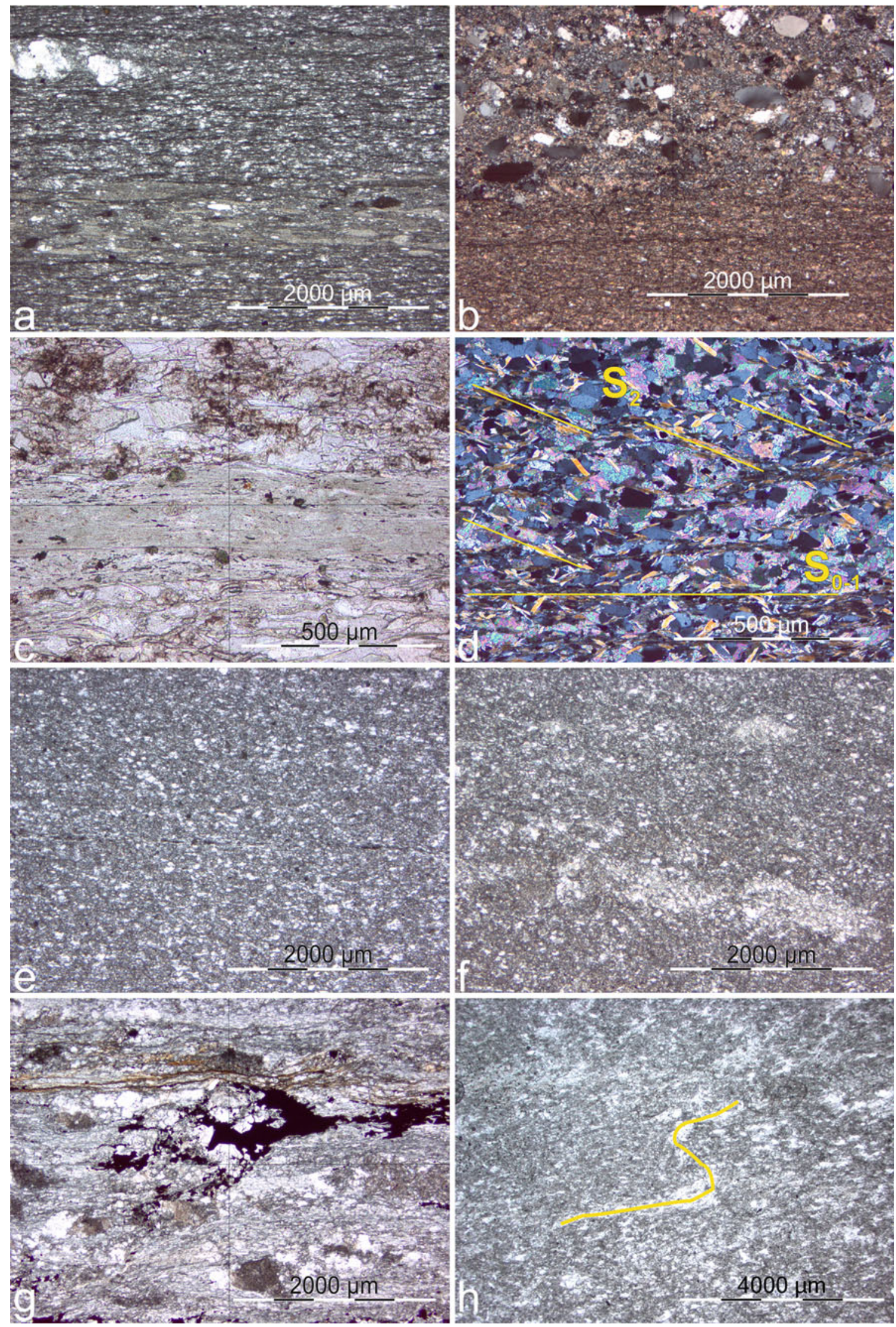
4 Fig. 5 Thin section images of the investigated samples. The slaty foliation is parallel to the image length. a Black dolomitic slate (U33) in cross-polarized light (CPL) with a large quartz clast visible in the upper left corner. b Piedra laja negra Rufo Hnos (U45) in CPL containing a distinct psammitic layer. c Piedra laja ocre (U38A) in plane polarized light (PPL), the phyllosilicatic layer in the center shows a light green coloration due to chlorite. Note the iron hydroxide staining above. d Piedra laja gris plomo (U38B) in CPL. $\mathrm{S}_{0-1}$ and $\mathrm{a} \mathrm{S}_{2}$ are indicated by the phyllosillicates. e Piedra laja verde oscura (U38C) in PPL showing a poor development of phyllosilicatic layers. f Piedra laja verde clara (U38D) in PPL, phyllosilicate layers are missing. g Piedra laja verde clara "macho" (U38M) in PPL. Relatively coarse dolomite, quartz and opaque grains are visible. h Sample UY-87 in PPL is a green dolomitic slate which shows a folded $\mathrm{S}_{0-1}$

sections (e.g. U38A, Fig. 5c) and in X-ray diffraction (Table 3). The phyllosilicates occur parallel to the $\mathrm{S}_{0-1}$ foliation and in some varieties also along a second foliation $\mathrm{S}_{2}$ (Fig. 5d) or to folds developed in a later deformation phase (Fig. 5h).

In the calculations using Slatenorm (Table 12), the normative chlorite mineral is defined as daphnite (Fe-Alchlorite) and the serpentine group consisting of the minerals serpentine ( $\mathrm{Mg}$-serpentine), amesite ( $\mathrm{Mg}$-Al-serpentine) and greenalite (Fe-serpentine). The serpentine group minerals were not identified in thin section and are not present in the X-ray diffractograms, being only present as normative minerals.

There is an inverse correlation between the normative amount of dolomite on the one side and the normative content of quartz + feldspar and mica on the other. The Piedra laja verde oscura (U38C) and verde clara (U38D) have the highest normative dolomite content of the commercial varieties analyzed and the lowest proportion of normative quartz and muscovite (Table 12; Fig. 4b). On the other hand, the Piedra laja rosada con gris (UY-106) shows the highest quartz and muscovite normative proportions and the lowest dolomite normative content.

Accessory minerals determined are feldspar, apatite, tourmaline, zircon and opaques (magnetite and pyrite). In the black Rufo Hnos (U45) variety, psammitic layers containing anhedral grains of plagioclase are recognizable with sizes similar to those of the quartz grains $(30 \mu \mathrm{m})$. The reddish colored varieties (U38A-U38M) show patches red and orange color (possibly iron hydroxides, Fig. 5c).

The black slates have lower proportions of normative dolomite when compared to the colored slates and show, in turn, higher proportions of normative quartz and phyllosilicates (muscovite, chlorite and illite). This relationship between the mineralogical composition and the color is confirmed by the variety Piedra laja gris plomo (U38B), which is the darkest slate of the northern district (AMVD) and shows the lowest proportions of dolomite in the entire mining district.

\section{Pelitic slates}

The pelitic slates are the most heterogeneous of the rocks investigated (Table 12; Figs. 4, 6). These rocks have a high proportion of normative phyllosilicates (between 38 and $68 \%$ ), mainly muscovite, but also chlorite, chloritoid and minor biotite (in Ardósia Apiúna, AP). The other main constituents are quartz and feldspar.

Muscovite appears as euhedral crystals with sizes ranging between 50 and $100 \mu \mathrm{m}$. They have an aspect ratio of 20 and are oriented parallel to the foliation. In the psammitic layers of sample AP, muscovite grains show sizes up to $250 \mu \mathrm{m}$ with an aspect ratio up to 16 . Chlorite is the dominant phyllosilicate in the Piedra laja San Luís (AR). Chlorite is observable in the varieties Pizarra de techar La Fraguina (sample 120) and Valdemiguel (sample 150), where they appear as mica fishes ranging from 60 to $100 \mu \mathrm{m}$ in size with an aspect ratio up to two (Fig. 6f). This observation has also been reported by Ruiz García (1977) and García-Guinea et al. (1998).

Chloritoid is present in the Ardósia de Canelas (PL) as euhedral crystals with a size range of 50-100 $\mu \mathrm{m}$ and an aspect ratio of 10 . Their long axes are parallel, transverse or perpendicular to the foliation (Fig. 6h).

Another important constituent is quartz with a smaller variation of its proportion, the normative content ranges between 28 and $34 \mathrm{wt} \%$. This mineral forms anhedral grains with sizes ranging between 40 and $80 \mu \mathrm{m}$, and up to $300 \mu \mathrm{m}$ in size in the Ardósia de Canelas (PL) or $600 \mu \mathrm{m}$ in the psammitic layers of the Ardósia Apiúna (AP) (Fig. 6a). Commonly, in the more phyllosilicate-rich slates the grains are elongated parallel to the foliation with an aspect ratio up to six (e.g., Pizarra de techar La Fraguina) (Fig. 6e, f). In the other varieties, those with lower phyllosilicate contents, the grains are very well rounded. Undulose extinction was not observed.

The other main constituent is feldspar, whose normative amount varies between 0 and $20.3 \mathrm{wt} \%$. Due to the very fine grain size, determination with the petrographic microscope was not possible, with the exception of the feldspars in the psammitic layers of the Ardósia Apiúna (AP). The accessory minerals consist of rutile, apatite, magnetite and pyrite. In the Sauerland Schiefer (WS) carbonate is also observable as an accessory mineral.

Varieties with a higher content of normative phyllosilicates (and lower feldspar) are Arouca (PL), La Fraguina (sample 120), Valdemiguel (sample 150), Theuma Fruchtschiefer (TH) and Sauerland (WS). The high amount of $\mathrm{C}_{\text {org }}$ in the form of graphite ranges between 0.39 and $0.53 \mathrm{wt} \%$ (Table 2), and is responsible for their characteristic black or dark gray color. An exception to this characteristic is sample $\mathrm{TH}$, which shows no presence of $\mathrm{C}_{\mathrm{org}}$ 

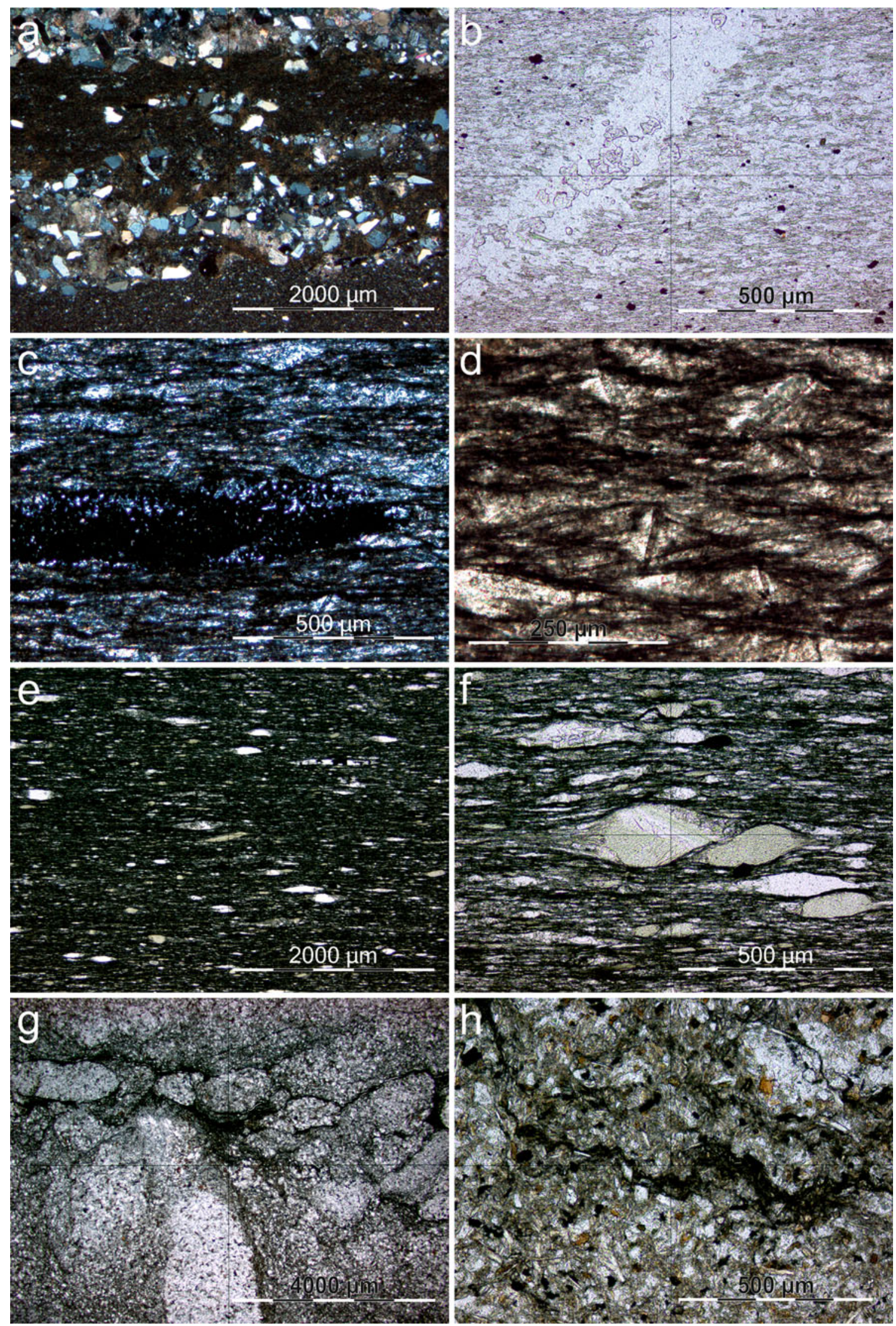
4 Fig. 6 Thin section images of the investigated slates. The slaty foliation is parallel to the image length. a Ardósia Apiúna (AP) in CPL with quartz grains showing undulatory extinction in the psammitic layers. b Piedra laja San Luís (AR) in PPL. Quartz vein crosscuts the foliation as determined by the alignment of chlorite. c Ardósia de Canelas (PL) in CPL. Quartz microlithons between phyllosilicatic layers and a lens of tiny pyrite porphyroblasts. d Ardósia de Canelas (PL) in PPL. Note the chloritoid porphyroblast surrounded by or transversal to the foliation. e Pizarra de techar La Fraguiña (120) in CPL with a very well-developed foliation. Quartz and chloritoid grains are elongated parallel to the foliation. $\mathbf{f}$ Detail of the texture in the Pizarra de techar La Fraguiña (120) in PPL. Note the chlorite "fish" in the center with a light green color and the white quartz grains. g Xisto negro de Foz Côa (PO) in PPL with opaques and a phyllosilicate-rich, irregular solution transfer foliation. Note the lighter and darker domains, the latter with a relatively higher proportion of phyllosilicates and a finer grain size. $\mathbf{h}$ Detail of the solution transfer foliation in the Xisto negro de Foz Côa (PO) in PPL

and whose dark gray color is dotted by millimeter-sized chlorite pseudomorphs after cordierite (Fischer et al. 2011).

Slaty pelites with lower amounts of normative phyllosilicates are, in decreasing order: Piedra laja San Luis (AR), Ardósia Gaspar (GA), Ardósia Apiúna (AP) and Piedra laja Puntas del Chafalote (UY-108). Higher proportions of normative serpentine minerals occur with respect to the other phyllosilicates. These rocks show green colors, due to the relatively high proportion of modal chlorite.

\section{Semipelitic slates}

Semipelitic slates are rocks with even lower normative phyllosilicate contents (Fig. 6). Their main constituent is quartz, whose normative abundance ranges between 33 and $50 \mathrm{wt} \%$, and occurs as anhedral rounded grains of up to $120 \mu \mathrm{m}$. In the Xisto negro de Foz Coa (PO) two families of grain sizes can be differentiated, the smaller group ranges $40-50 \mu \mathrm{m}$ and the larger 80-100 $\mu \mathrm{m}$ (Fig. 6g).

Feldspar, with 14-34 wt\% normative abundance, is mainly represented by plagioclase grains showing a similar grain size to quartz (40 and $100 \mu \mathrm{m}$ ). The normative phyllosilicates comprise 28-30 wt\%, and consist of muscovite, biotite and chlorite. Muscovite appears as euhedral crystals $150 \mu \mathrm{m}$ in size and has an aspect ratio up to 15. Biotite is subhedral to anhedral and finer in sample PO (up to $30 \mu \mathrm{m}$ in size with an aspect ratio of around one). In the Lotharheil Schiefer (LO) biotite is subhedral, shows a grain size up to $100 \mu \mathrm{m}$ and an aspect ratio of around three. Euhedral hexagonally shaped crystals of chlorite are less frequent and around $30 \mu \mathrm{m}$ in size.

Calcite appears as anhedral crystals generally $80 \mu \mathrm{m}$ in size. Sometimes it exhibits a poikiloblastic texture in the LO (patchy-shaped grains) ranging in size between 150 and $300 \mu \mathrm{m}$, partially surrounding grains of quartz and muscovite. The normative abundance is higher in the LO (5.5 wt $\%$ ). Very coarse calcite crystals are also found occurring as veins in the PO (e.g., one calcite vein is $2.8 \mathrm{~mm}$ in length and $0.16 \mathrm{~mm}$ wide).

Accessory minerals include euhedral apatite and zircon, and anhedral to subhedral magnetite and pyrite. They are disseminated throughout the rock and show very fine grain sizes up to $20 \mu \mathrm{m}$.

\section{Opaque minerals}

The opaque minerals present in all the slates include magnetite, chalcopyrite and pyrite. Their shapes, proportion and distribution vary widely from slate to slate.

In the dolomitic slates the opaques mainly consist of magnetite and pyrite. Magnetite appears in almost all samples as $5-20 \mu \mathrm{m}$ anhedral to euhedral crystals, normally disseminated in the rock. Pyrite usually appears as 5-20 $\mu \mathrm{m}$ anhedral crystals. In some of the samples, relatively coarser $(350-500 \mu \mathrm{m})$ euhedral crystals are present, in veins or in the foliation surface, especially in the black varieties (U33, U45 and UY-85) and in a non-fissile variety (U38M) (Fig. 5g). Chalcopyrite is present in two of the samples as euhedral crystals 5-20 $\mu \mathrm{m}$ in size.

Magnetite and pyrite are also the main opaque constituents of the pelitic slates. These two minerals are present as very fine-grained disseminated crystals (around $20 \mu \mathrm{m}$ ). Pyrite tends to be euhedral and magnetite subhedral to anhedral. However, in the variety Ardósia de Canelas (PL) the fine-grained pyrite crystals $(20 \mu \mathrm{m})$ occur in lenses of up to $2.6 \mathrm{~mm}$ in length and $1.0 \mathrm{~mm}$ in width.

In the Piedra laja San Luis (AR), subhedral magnetite is the dominant opaque mineral and shows two distinct grain sizes. The finer grained crystals are about $20 \mu \mathrm{m}$ in size and the coarser grains are up to $110 \mu \mathrm{m}$. Pyrite crystals are subhedral and tend to be elongated, having a size up to $130 \mu \mathrm{m}$ with an aspect ratio of four. Their proportion in these rocks is relatively higher than for the other rocks analyzed.

Magnetite and pyrite also appear as anhedral to subhedral grains in the semipelitic slates. They have very fine grain sizes (up to $20 \mu \mathrm{m}$ ) and are evenly disseminated throughout the rocks. Pyrite is also found in veins, around $60 \mu \mathrm{m}$ thick and $15 \mathrm{~cm}$ length. Together with magnetite pyrite is also found along solution transfer surfaces.

\section{Rock fabric}

The rock fabric together with the mineral composition controls the physical and mechanical properties and the décor of a dimensional stone, which holds true especially 
Fig. 7 Rock fabrics (see explanation in the text)
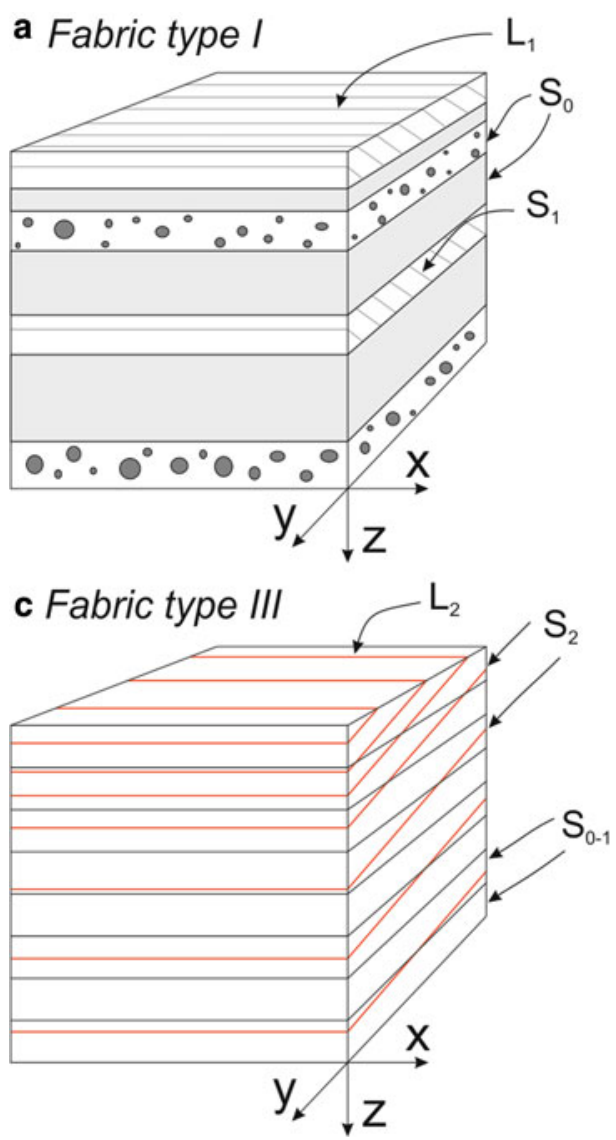

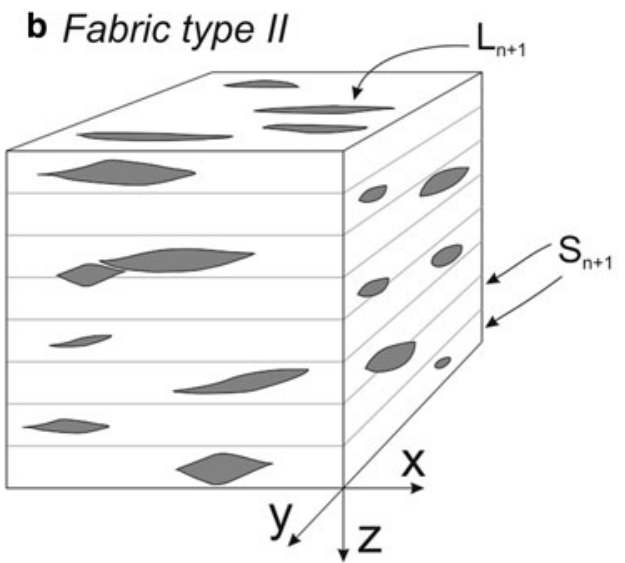

d Fabric type IV

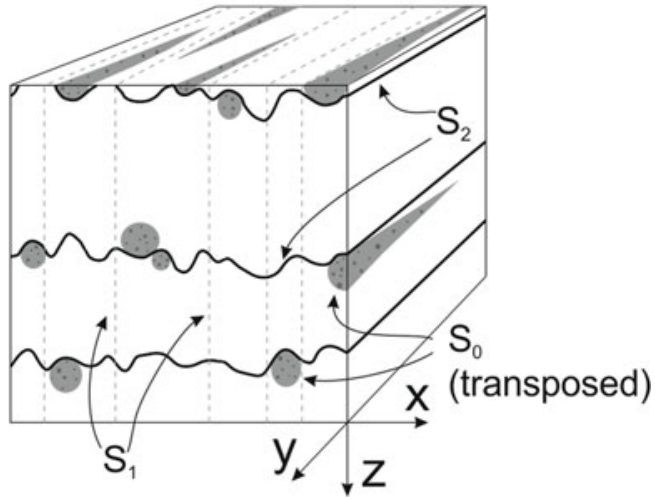

in the case of the slates. As illustrated in Fig. 7, four main rock fabric types have been determined for the slates analyzed. The presence of a spaced foliation is a characteristic feature common in the majority of the fabric types. This foliation is defined by cleavage domains that are essentially composed of orientated phyllosilicates and microlithons consisting of an ensemble of minerals that are in between these cleavage domains (Passchier and Trouw 1996). According to Shelley (1993), the cleavage domains are M or $\mathrm{P}$ domains (for mica- or phyllosilicate-rich domains) and the microlithons are the $\mathrm{Q}$ domains (quartz-rich domains). In the dolomitic slates the microlithons have, in addition to quartz, also a high proportion of dolomite.

1. Fabric type I The cleavage domains are practically absent or poorly developed due to the very low grade metamorphic conditions that the rock underwent. The rock splits parallel to the bedding plane, especially along bedding planes that are characterized by significant differences in grain sizes. These are the so-called parallel slates. The individual grains do not show any preferred orientation and are equidimensional. The slate Ardósia Gaspar (GA) is a good example for this fabric type (Fig. 7a). This sample shows layers that are more fine-grained, with a poorly developed $\mathrm{S}_{1}$ foliation, which determines an intersection lineation $\left(\mathrm{L}_{1}\right)$ with the foliation $\mathrm{S}_{0}$.

2. Fabric type II is characterized by the abundance of cleavage domains determining a very well-developed slaty cleavage, being the plane along which the rock splits. Individual quartz and chlorite grains of the microlithons are deformed, generally showing oblate to prolate shapes. A stretching lineation is defined by the grains that are oriented with their long axis parallel to the foliation plane. A typical example is the Spanish slate Pizarra de techar La Fraguiña (sample 120), whose fabric is illustrated schematically in Fig. 7b. A special case of this fabric type is the slate Ardósia de Canelas (PL), where the long axes of chloritoid porphyroblasts are perpendicular, transversal or parallel to the foliation and also millimeter-thick lenses composed of tiny pyrite porphyroblasts occur. The chloritoids of Ardósia de Canelas are wrapped by the last foliation $S_{n+1}$, therefore they are pre-deformation phase $\mathrm{D}_{n+1}$. They are post-tectonic to the foliation developed in deformation phase $\mathrm{D}_{n}$, since they are not completely aligned.

3. Fabric type III A wider range of fabric types is summarized in this group. This group shows more than one foliation and the angle between the planar fabrics 
may differ. The main foliation, which can be described as a slaty cleavage, is generally parallel to the original bedding plane of the protolith due to transposition, e.g., in the slate Laja Negra Rufo Hnos (U45) and it is defined as $\mathrm{S}_{0-1}$. In most of the cases another foliation occurs $\left(\mathrm{S}_{2}\right)$, as some of the phyllosilicate flakes were reoriented in response to a later folding event. Consequently, this kind of fabric also contains a lineation as the result of the intersection of these two foliations $\left(\mathrm{L}_{2}\right)$. If both foliations have a relatively small angle between each other (e.g., $8^{\circ}$ in sample UY-45) scales or flakes that easily break will develop. In cases where the angle between both foliations is larger (e.g., $15^{\circ}$ in sample $\mathrm{U} 38 \mathrm{~B}$ or $23^{\circ}$ in $\mathrm{U} 38 \mathrm{~A}$ ), the main foliation shows undulations on the order of microns. In Fig. 7c this fabric is illustrated for the Uruguayan dolomitic slates. For commercial use the $S_{0-1}$ should be the dominant foliation because it controls the mechanical behavior. Additionally, the angle between both foliations should not be larger than $30^{\circ}$, because then the rock does not split easily parallel to $\mathrm{S}_{0-1}$ and the surface obtained will not be smooth (e.g., development of steps).

4. Fabric type IV It is mainly characterized by the lack of flatness of the foliation surface. The most complex example is illustrated by the Xisto negro de Foz Côa (PO), which shows a foliation characterized by pressure solution and solution transfer processes and two domains with different grain sizes. The cleavage domains are composed of pyrite, muscovite and biotite and their thickness varies between 8 and $65 \mu \mathrm{m}$. The microlithons comprise very fine-grained domains (quartz grains $<63 \mu \mathrm{m}$ ) and coarser grained domains (quartz up to $80 \mu \mathrm{m}$ ). The coarser grained domains are prolate, $1-5 \mathrm{~mm}$ in diameter and $1-10 \mathrm{~cm}$ in length. Their long axes define a lineation parallel to the foliation plane very often surrounded by the solution transfer foliation. Another, less well-developed foliation can be observed perpendicular to the main foliation, which is characterized by pelitic domains. Additionally, carbonate, quartz and pyrite veins crosscut the rock in all directions. As for the Lotharheil Schiefer (LO), this kind of fabric is responsible for a very rough foliation surface (Fig. 7d).

\section{Mica layers and mass value}

The mass value is a very important parameter to be taken into account when evaluating the suitability of a slate for commercial use, as it controls its fissility. This parameter was developed by Bentz and Martini (1968) and later included in the DIN EN 12326-2 (2000).
Table 4 Width of mica layers, mica layers per mm and mass value calculated for the samples analyzed

\begin{tabular}{llrc}
\hline Sample & $\begin{array}{l}\text { Width of mica } \\
\text { layers }(\mathrm{mm})\end{array}$ & Mica layers $/ \mathrm{mm}$ & Mass value \\
\hline U33 & 0.007 & 39.7 & 2.96 \\
U45 & 0.003 & 16.9 & 0.51 \\
U38A & 0.106 & 9.7 & 10.28 \\
U38B & 0.010 & 25.5 & 2.56 \\
U38C & 0.008 & 11.0 & 0.87 \\
U38D & 0.013 & 7.5 & 0.98 \\
U38M & 0.007 & 20.4 & 1.38 \\
AP & 0.010 & 2.5 & 0.25 \\
GA & 0.010 & 1.2 & 0.12 \\
AR & 0.007 & 108.4 & 7.22 \\
PL & 0.020 & 40.5 & 8.12 \\
WS & 0.011 & 55.8 & 5.99 \\
120 & 0.004 & 123.7 & 5.50 \\
150 & 0.009 & 62.8 & 5.57 \\
PO & 0.042 & 0.7 & 0.28 \\
LO & 0.032 & 0.5 & 0.16 \\
\hline
\end{tabular}

No clear knowledge exists of how exactly the mica layers influence the flexural strength and workability of the slates. The modality for measuring the mica layers is described in European technical norm for roofing slates (DIN EN 12326-2 2000); however, this parameter should be taken as an approximation. Variations of 10-15 mica layers per mm can occur depending on the person measuring and the procedure used (e.g., measurement with the microscope or using a printed image). Wagner (2007) calculated the mass value for several slates. This parameter is the product of the number of mica layers per $\mathrm{mm}$ by the average width of the mica layers multiplied by ten.

The values obtained for the studied slates varies from 0.12 to 8.12 , and although these values are lower when compared with those obtained by Wagner (2007), a general trend can be observed (Table 4; Fig. 8). The dolomitic slates show lower mass values. They represent a lower number of mica layers per millimeter, between 7.5 and 39.7, and similar mica layer widths as the pelitic slates, with the exception of the Piedra laja ocre (U38A) that shows a mica layer width of $0.106 \mathrm{~mm}$.

The phyllosilicate-rich pelitic slates show a very high mica layer per millimeter, between 40.5 (Ardósia de Canelas) and 123.7 (Pizarra de techar La Fraguina). Although the Ardósia Gaspar and Ardósia Apiuna are pelitic slates, they have with a very low mica layer number per millimeter of 1.2 and 2.5 , respectively.

The semipelitic slates show the lowest mass values as they represent extremely low values of mica layers per millimeter, between 0.5 and 0.7. Wagner (2007) observed 


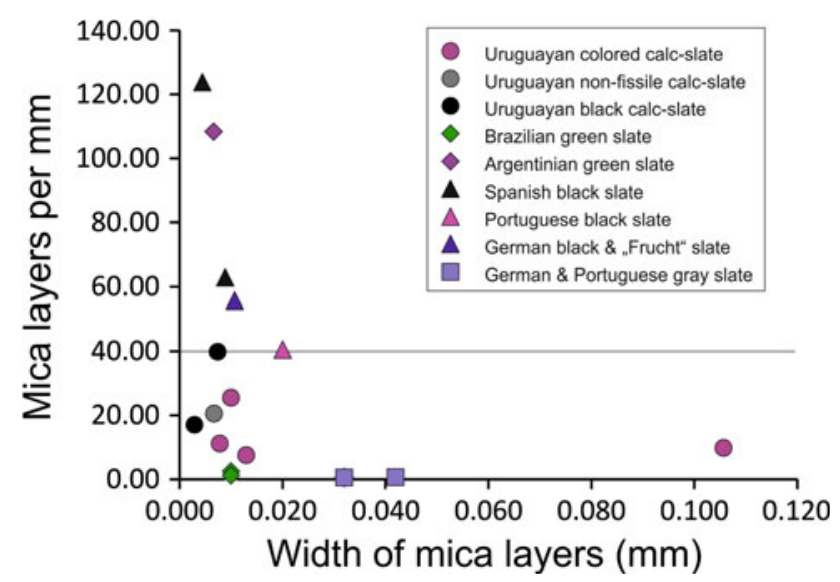

Fig. 8 Diagram of width of mica layers versus mica layers per mm (modified after Wagner 2007)

that the slates with a number of mica layers per millimeter lower than 40 are not suitable as roofing and façade slates. The analyzed slates that have a higher number of mica layers per millimeter than 40 are the Spanish roofing slates (samples 120 and 150), Piedra Laja San Luis (AR), Sauerland Schiefer (SW) and Ardósia de Canelas (PL).

\section{Physical and mechanical rock properties}

The application of a slate is fundamentally determined by its physical and mechanical properties. The relevant properties are flexural strength, relative water uptake, temperature cycling tests, and stability during freezing, color, acid, leaching and heat. According to Wagner (2007), a low flexural strength is associated with a high water uptake. At a water uptake of about $<0.4 \mathrm{wt} \%$ a flexural strength of 50-70 MPa is expected (see discussion in Wagner 2007). Also a high water uptake can be related to the weathering of ore and carbonate minerals.

\section{Bulk density, matrix density, porosity}

The mechanical instability or mechanical deterioration of the rock fabric, for example through frost damage or other climatic influences, is related to a high porosity, therefore a low density, but also to a high water uptake. For the application as roofing or façade cladding a comparable high flexural strength is required.

The bulk density, the matrix density and the porosity were measured using the Archimedes method, as described in Monicard (1980). The bulk density of the investigated slates ranges from 2.72 to $2.83 \mathrm{~g} / \mathrm{cm}^{3}$ (Table 5). The lowest values are observed for the Ardósia Apiúna (AP) and Lotharheil Schiefer (LO), while the higher values belong to the Piedra laja verde oscura (U38C), Piedra laja verde clara (U38D) and Piedra laja verde clara "macho" (U38M).

The matrix density shows a similar variation, between 2.73 and $2.87 \mathrm{~g} / \mathrm{cm}^{3}$ (Table 5) for the Ardósia Apiúna (AP) and Lotharheil Schiefer (LO), varieties which show the lowest values. Ardósia de Canelas (PL) shows the highest matrix density corresponding to the high content of $\mathrm{Fe}_{2} \mathrm{O}_{3 \mathrm{t}}$ $(10.21 \mathrm{wt} \%)$, which is mainly present as magnetite lenses parallel to the foliation.

The dolomitic slates show relatively high matrix densities, e.g., between 2.78 and $2.84 \mathrm{~g} / \mathrm{cm}^{3}$. This is due to the higher proportion of dolomite in these rocks, a mineral with a higher density $\left(2.87 \mathrm{~g} / \mathrm{cm}^{3}\right.$, Robie and Bethke 1966) than the main constituents of slates (quartz and the chlorite group).

The porosity of the slates is normally low, between 0.10 and $2.46 \%$ (Table 5). The lowest value is registered by the Piedra laja verde oscura (U38D) and the highest is observed for the Ardósia de Canelas (2.46\%). With respect to the porosity two groups of slates can be distinguished: one group, represented by the dolomitic slates has values lower than $0.30 \%$ corresponding to a higher bulk density. The second group is represented by slates with $\geq 0.30 \%$ porosity, e.g., quartz- and phyllosilicate-rich slates.

The values of the bulk density of the slates given in Table 5 are higher than the $75 \%$ quartile for metamorphic rocks discussed by Mosch and Siegesmund (2007). Comparing the porosity values compiled by these authors, it is obvious that the dolomitic slates represent the upper (dolomitic slates) and lower extreme values (pelitic slates), whereas the pelitic and semipelitic varieties are the upper outliers.

The average pore radius determined by mercury injection porosimetry ranges between $0.01 \mu \mathrm{m}$ for the Piedra laja negra Rufo Hnos (U45) and $0.31 \mu \mathrm{m}$ in the Pizarra de techar Valdemiguel (150). Most pore radii range between 0.05 and $5.31 \mu \mathrm{m}$. The lowest values are observed for the following samples, e.g., Piedra laja negra Rufo Hnos (U45), Ardósia Apiúna (AP) and Theuma Fruchtschiefer (TH); while Xisto negro de Foz Côa (PO) exhibits the highest value. According to Klopfer (1985), in micropores with a pore diameter $<0.1 \mu \mathrm{m}$, water will condense at relative humidity $(\mathrm{RH})$ values below $99 \%$. Capillary suction is practically relevant to materials for pore diameters between $1 \mu \mathrm{m}$ and $1 \mathrm{~mm}$, the so-called capillary pores.

The atmospheric water uptake or absorption determined following the DIN EN 13775 (2001) is relatively low for all samples studied covering the range between 0.03 and $0.74 \mathrm{wt} \%$ (Table 5). Most of the samples show values lower than $0.30 \mathrm{wt} \%$. The exceptions are the Theuma 
Table 5 Density, porosity and pore radii distribution in the analyzed samples

\begin{tabular}{|c|c|c|c|c|c|c|c|}
\hline Trade name & ID & $\begin{array}{l}\text { Bulk density } \\
\left(\mathrm{g} / \mathrm{cm}^{3}\right)\end{array}$ & $\begin{array}{l}\text { Matrix density } \\
\left(\mathrm{g} / \mathrm{cm}^{3}\right)\end{array}$ & $\begin{array}{l}\text { Porosity } \\
(\%)\end{array}$ & $\begin{array}{l}\text { Average pore } \\
\text { radii }(\mu \mathrm{m})\end{array}$ & $\begin{array}{l}\text { Most frequent pore } \\
\text { radii }(\mu \mathrm{m})\end{array}$ & $\begin{array}{l}\text { Water uptake } \\
\text { atm. (wt } \% \text { ) }\end{array}$ \\
\hline $\begin{array}{l}\text { Piedra laja negra, } \\
\text { Caorsi Hnos }\end{array}$ & U33 & 2.78 & 2.78 & 0.19 & 0.253 & 0.531 & 0.06 \\
\hline $\begin{array}{l}\text { Piedra laja negra, Rufo } \\
\text { Hnos }\end{array}$ & U45 & 2.80 & 2.81 & 0.16 & 0.010 & 0.005 & 0.05 \\
\hline Piedra laja ocre & U38A & 2.82 & 2.83 & 0.23 & 0.069 & 0.021 & 0.12 \\
\hline Piedra laja gris plomo & U38B & 2.82 & 2.83 & 0.17 & 0.056 & 0.013 & 0.07 \\
\hline $\begin{array}{l}\text { Piedra laja verde } \\
\text { oscura }\end{array}$ & $\mathrm{U} 38 \mathrm{C}$ & 2.83 & 2.84 & 0.13 & 0.073 & 0.084 & 0.06 \\
\hline Piedra laja verde clara & U38D & 2.83 & 2.83 & 0.10 & 0.061 & 0.005 & 0.05 \\
\hline $\begin{array}{l}\text { Piedra laja verde clara } \\
\text { "macho" }\end{array}$ & U38M & 2.83 & 2.83 & 0.26 & 0.171 & 0.021 & 0.07 \\
\hline $\begin{array}{l}\text { Piedra laja Puntas del } \\
\text { Chafalote }\end{array}$ & $\begin{array}{l}\text { UY- } \\
108\end{array}$ & 2.72 & 2.74 & 0.62 & n.d. & n.d. & 0.24 \\
\hline Ardósia Apiúna & $\mathrm{AP}$ & 2.72 & 2.75 & 1.05 & 0.034 & 0.005 & 0.24 \\
\hline Ardósia Gaspar & GA & 2.75 & 2.77 & 0.59 & & & 0.09 \\
\hline Piedra Laja San Luis & $\mathrm{AR}$ & 2.78 & 2.80 & 0.80 & 0.18 & & 0.28 \\
\hline Ardósia de Canelas & PL & 2.80 & 2.87 & 2.46 & & & 0.74 \\
\hline Sauerland Schiefer & WS & 2.77 & 2.79 & 0.51 & 0.077 & 0.008 & 0.20 \\
\hline $\begin{array}{l}\text { Pizarra de techar La } \\
\text { Fraguiña }\end{array}$ & 120 & 2.77 & 2.80 & 0.84 & 0.142 & 0.005 & 0.14 \\
\hline $\begin{array}{l}\text { Pizarra de techar } \\
\text { Valdemiguel }\end{array}$ & 150 & 2.78 & 2.79 & 0.39 & 0.310 & 0.531 & 0.16 \\
\hline $\begin{array}{l}\text { Xisto negro de Foz } \\
\text { Côa }\end{array}$ & $\mathrm{PO}$ & 2.74 & 2.75 & 0.42 & 0.245 & 5.309 & 0.10 \\
\hline Lotharheil Schiefer & LO & 2.72 & 2.73 & 0.30 & 0.020 & 0.005 & $0.03 *$ \\
\hline Theuma Fruchtschiefer & $\mathrm{TH}$ & $2.74 * *$ & n.d. & $0.95 * *$ & $0.096^{+}$ & $0.005^{+}$ & $0.40 * *$ \\
\hline
\end{tabular}

* Data after Siegesmund and Stein (2007); $* *$ data after Weiss et al. (2004), ${ }^{+}$data after Fischer et al. (2011); ${ }^{++}$data after Natursteinwerk Theuma AG (2012)

Fruchtschiefer (TH) and the Ardósia de Canelas (PL) with values of around $0.40 \mathrm{wt} \%$ (Natursteinwerk Theuma AG 2012) and $0.74 \mathrm{wt} \%$, respectively. All the dolomitic slates show values $\leq 0.12 \mathrm{wt} \%$, in contrast to some pelitic and semipelitic slates (see Table 5).

The values of water uptake of the Uruguayan commercial slates are within the upper and lower quartile of the values for roofing slates compiled by Wagner (2007). Most of the slates belonging to the pelitic and semipelitic groups have values between both quartiles, but some of them (PL and $\mathrm{TH}$ ) show values higher than the upper quartile. If the water uptake is higher than $0.6 \mathrm{wt} \%$, the frost resistance must be determined using the DIN 52104 for 100 freezethaw cycles.

\section{Antimicrobial properties}

For the utilization of slates as countertops and even as cutting boards is relevant to know their antimicrobial properties. For this purpose the studied slates were exposed to two kinds of bacteria: Escherichia coli (E. coli) and Bacillus subtilis (B. subtilis) and a fungus: Aureobasidium pullulans (A. pullulans). Their growth after 10 days was evaluated. Two kind of standard medium were used for the growing of the bacteria: lysogeny broth (LB) and potatodextrose agar (PDA).

The results obtained are listed in Table 6. A lower growth of $E$. coli in the LB medium is observed while in most of the samples no growth is observed. The samples that show weak growth of this bacterium are Piedra laja negra Rufo Hnos (U45) and Pizarra de techar Valdemiguel (150). Ardósia Apiúna (AP) and Piedra laja verde clara "macho" (U38M) show a moderate growth. In PDA medium a higher growth is observed for some of the samples considered, especially in Piedra laja verde claro macho (U38M), Ardósia Apiúna (AP), Xisto negro de Foz Côa (PO) and the control sample Moskart Granite (U7), which show high growth (confluent growth of colonies).

In the case of $B$. subtilis a higher growth is observed for both mediums while for most samples it is moderate to high, with the exception of Ardósia de Canelas (PL) which shows 
Table 6 Bacterial growth on the studied slates in different growth mediums

\begin{tabular}{llll}
\hline Sample & $\begin{array}{l}\text { E. coli }(\mathrm{LB} / \\
\text { potato- } \\
\text { dextrose) }\end{array}$ & $\begin{array}{l}\text { B. subtilis }(\mathrm{LB} / \\
\text { potato- } \\
\text { dextrose) }\end{array}$ & $\begin{array}{l}\text { A. pullulans (max. } \\
\text { number of colonies/ } \\
\left.0.25 \mathrm{~mm}^{2}\right)\end{array}$ \\
\hline U33 & $0 / 0$ & $3 / 3$ & 0 \\
U45 & $1 / 2$ & $3 / 2$ & 0 \\
U38A & $0 / 2$ & $3 / 3$ & 0 \\
U38B & $0 / 0$ & $3 / 3$ & 0 \\
U38C & $0 / 0$ & $3 / 3$ & 0 \\
U38D & $0 / 0$ & $3 / 3$ & 0 \\
U38M & $2 / 3$ & $2 / 2$ & 0 \\
AP & $2 / 3$ & $0 / 3$ & $1-2$ \\
GA & $0 / 0$ & $3 / 3$ & 5 \\
AR & $0 / 2$ & $3 / 3$ & 0 \\
PL & $0 / 0$ & $1 / 1$ & 0 \\
WS & $0 / 0$ & $3 / 3$ & 0 \\
120 & $0 / 0$ & $3 / 3$ & 0 \\
150 & $1 / 2$ & $3 / 2$ & 0 \\
PO & $0 / 3$ & $3 / 2$ & 0 \\
U1 & $0 / 0$ & $2 / 2$ & 2 \\
U7 & $0 / 3$ & $3 / 3$ & $0-1$ \\
U27 & $0 / 2$ & $3 / 3$ & $0-2$ \\
\hline
\end{tabular}

The last three samples are sandstone (U1), granite (U7) and marble (U27) for comparison

$L B$ lysogeny broth and potato-dextrose agar

Evaluation of the growth: 0, no growth; 1-2, weak to moderate; 3 , confluent growth of colonies

a weak growth. Ardósia Apiúna (AP) shows no growth in LB medium and a very high growth in PDA medium.

For A. pullulans the number of colonies in $0.25 \mathrm{~mm}^{2}$ gives the information of the antimicrobial property of a slate. Most of the slates show no growth of colonies, with the exception of Ardósia Apiúna (AP) and Ardósia Gaspar (GA). The first pelitic slate show 1-2 colonies and GA show 5, which is the highest value registered for the samples considered. The control group, composed by sandstone, granite and marble, presents 0-2 colonies.

\section{Mechanical properties}

A coordinate system determined by the foliation and lineation observed in the rocks was established. The foliation determines the $x y$-plane and the lineation the $x$-direction.

\section{Flexural strength}

The relevance of the flexural strength in any dimensional stone is because this petrophysical property determines the resistance to bending stresses, such as those experimented on with rear-ventilated façades or stairways (Siegesmund and Dürrast 2011). According to these authors, the damages produced by the overcoming of these stresses are more important than those produced by shear or compressive stresses.

The fissility of a natural layer is a positive aspect during the manufacturing of building elements on one hand; on the other hand, it is the weakest point of strength in the construction. Therefore, each contribution using fissile dimensional stones must take into account the flexural strength. Flexural strength tests have to be performed and to be compared to the potential flexural forces in the construction. This is of primary importance for the following construction elements: façade panels with lateral and back slide anchors, floor tiles with dynamic shear stress (heavyduty loading) and construction elements with static loads within the foliation plane (e.g., columns). Minimum requirements for the thickness of construction elements are therefore dependent on the dimension of the surface in relation to the flexural strength. Also lithological and tectonically induced points of weaknesses have to be considered.

The anisotropy of the slates fabric must be carefully taken into account in the evaluation of most of their petrophysical properties. The most important fabric elements in slates are the planar structures, e.g., slaty cleavage, as they are surfaces of natural weakness, i.e., the preferred splitting direction in slates. They determine the quality and uses of these rocks, being the most important property for the production of thin tiles for roof or façade cladding. Therefore, in this investigation the flexural strength is only measured with the load applied perpendicular to the foliation, the $z$-direction, as described in Siegesmund and Dürrast (2011).

The presence of linear elements is also of importance because it may significantly influence the flexural strength. The lineation can be the result of the intersection of two planar elements as discussed in the subchapter rock fabrics and illustrated in Fig. 7 for the dolomitic slates (U33 and U38A). Slate producers also define the lineation as "grain" (hilo in Spanish and Faden in German), which defines a penetrative lineation parallel to the $x$-direction of the deformation ellipsoid (García-Guinea et al. 1998; Wagner 2007). In the Spanish roofing slates (La Fraguiña and Valdemiguel), the grain is defined by deformed grains of quartz and chlorite.

Considering these two main structural elements, the flexural strength was determined according to the DIN EN 12372 (1999). In addition the load was applied perpendicular to the bedding and with the lineation parallel (longitudinal) and perpendicular (transverse) to this linear load (see Fig. 9). The flexural strength for the studied slates 


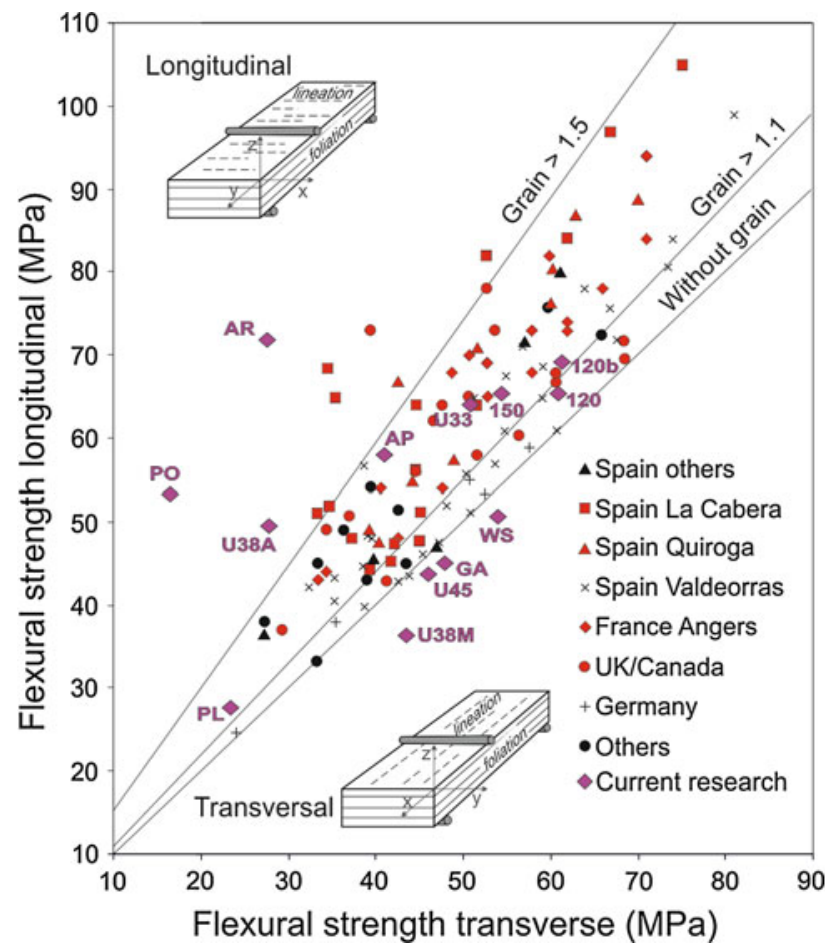

Fig. 9 Flexural strength transverse to lineation versus flexural strength parallel to foliation (modified after Wagner 2007)

varies from 16.4 to $71.9 \mathrm{MPa}$ (Table 7). The lowest value of $16.4 \mathrm{MPa}$ was measured in the Xisto negro de Foz Côa (PO) in the transversal direction. Piedra laja San Luis (AR) shows the highest value, 71.9 MPa, for the longitudinal direction (Mosch 2008).

Wagner (2007) presented a diagram relating the values of flexural strength obtained for several slates in the two directions. All slates considered show higher values in the longitudinal direction (Fig. 9), which is similar to the current investigation, although in many cases the difference between both values is within the standard deviation (e.g., Ardósia Gaspar, Pizarra de techar La Fraguiña). Nevertheless, for the Piedra laja verde clara "macho" (U38M), the flexural strength in the longitudinal direction is $16 \%$ lower than in the transverse direction.

The most extreme anisotropy is evidenced by Xisto negro de Foz Coa (PO), which shows a flexural strength value three times higher in the longitudinal direction than in the transverse one. This behavior is related to linear elements of the rock fabric. As described in the subchapter rock fabric, this rock represents coarser grained domains with prolate shapes that are limited by solution transfer foliation and surrounded by fine-grained domains. When the flexural load is applied parallel to the long axes of this prolate domain, the solution transfer foliation acts as cement and raises the strength of the rock. On the other hand, when the load is applied perpendicular to these prolate domains, just the contacts between the grains have to be broken, which are weaker in comparison with the solution transfer foliation.

A negative correlation occurs between the flexural strength and water uptake as illustrated by Wagner (2007). Figure 10 shows this relationship. The samples showing relatively high water uptake (values higher than $0.60 \mathrm{wt} \%$ ) are the ones with the lowest flexural strength (PL). The samples showing the highest flexural strength have relatively low water uptake; generally below $0.40 \mathrm{wt} \%$ as seen in samples 120, 150 and U33. A1 and A2 are codes defined in the DIN EN 12326-1. The first comprises the slates with water uptake below $0.6 \mathrm{wt} \%$, which are freeze-thaw resistant. The second code is used when a slate has a water uptake over $0.6 \mathrm{wt} \%$. A freeze-thaw test of 100 cycles must be performed in order to prove the stability of the rock in cold climates. In addition, Wagner (2007) takes into account the NF norm used in France, whereby the resistance to freeze-thaw processes requires a water uptake below $0.4 \mathrm{wt} \%$.

All the samples analyzed in this study, with the exceptions of PL and TH, have water uptakes below $0.4 \mathrm{wt} \%$ (see Fig. 10). They belong to the category A1, and hence, stable against freeze-thaw phenomena.

\section{Uniaxial compressive strength}

Another important parameter to be determined for rocks is the uniaxial compressive strength (UCS), which is the maximum compressive stress in one direction until it fails. This property is especially relevant for rock elements that have to bear a planar load (Siegesmund and Dürrast 2011), which is seldom the case in slates. Therefore, this property was determined only for two slate varieties: Piedra laja negra Rufo Hnos (U45) and Piedra laja gris plomo (U38B). For these samples the test was performed using the $x-y-z$ coordinate system (see Table 8 ) following the DIN EN 1926 (1999). The UCS values show the maximum differences between the $x$ - and $y$-directions, e.g., $191 \mathrm{MPa}$ in the $x$-direction and $116 \mathrm{MPa}$ in $y$-direction for $\mathrm{U} 45$ (Table 8). Such anisotropy is related to the influence of the $\mathrm{S}_{2}$ foliation, which weakens the UCS of the rock in the $y$-direction. This is also true for the Piedra laja San Luís (AR), whose values are between $143 \mathrm{MPa}$ ( $y$-direction) and $215 \mathrm{MPa}$ ( $x$-direction) (Mosch 2008).

The UCS values for other slates found in the literature lack orientation, and therefore, the directional dependence is unknown. For the Portuguese commercial slates the UCS values are $144 \mathrm{MPa}$ (Xisto negro de Foz Côa, PO) and $159 \mathrm{MPa}$ (Ardósia de Canelas, PL) (Laboratório Nacional de Energia e Geologia 2012). The lowest value is $90 \mathrm{MPa}$ for the Theuma Fruchtschiefer (Natursteinwerk Theuma AG 2012), while Siegesmund and Stein (2007) found 
Table 7 Mechanical properties of the samples analyzed

\begin{tabular}{|c|c|c|c|c|c|c|}
\hline \multirow[t]{2}{*}{ Trade name } & \multirow[t]{2}{*}{ ID } & \multicolumn{3}{|c|}{ Abrasion strength $\left(\mathrm{cm}^{3} / 50 \mathrm{~cm}^{2}\right)$} & \multicolumn{2}{|c|}{ Flexural strength (MPa) } \\
\hline & & $x$ & $y$ & $z$ & Q & $\mathrm{L}$ \\
\hline Piedra laja negra, Caorsi Hnos & U33 & n.d. & n.d. & 20.6 & $50.9 \pm 5.8$ & $64.1 \pm 7.0$ \\
\hline Piedra laja negra, Rufo Hnos & $\mathrm{U} 45$ & 10.1 & 7.6 & 8.1 & $46.0 \pm 6.0$ & $43.6 \pm 6.3$ \\
\hline Piedra laja ocre & $\mathrm{U} 38 \mathrm{~A}$ & n.d. & n.d. & 10.1 & $27.7 \pm 3.2$ & $49.6 \pm 2.2$ \\
\hline Piedra laja gris plomo & $\mathrm{U} 38 \mathrm{~B}$ & 8.9 & 10.2 & 11.9 & n.d. & n.d. \\
\hline Piedra laja verde oscura & $\mathrm{U} 38 \mathrm{C}$ & n.d. & n.d. & n.d. & n.d. & n.d. \\
\hline Piedra laja verde clara & $\mathrm{U} 38 \mathrm{D}$ & n.d. & n.d. & 5.2 & n.d. & n.d. \\
\hline Piedra laja verde clara „macho” & $\mathrm{U} 38 \mathrm{M}$ & n.d. & n.d. & 10.8 & $43.5 \pm 2.3$ & $36.4 \pm 1.3$ \\
\hline Piedra laja Puntas del Chafalote & UY-108 & n.d. & n.d. & 6.3 & n.d. & n.d. \\
\hline Ardósia Apiúna & $\mathrm{AP}$ & n.d. & n.d. & 19.4 & $41.0 \pm 8.8$ & $58.0 \pm 9.8$ \\
\hline Ardósia Gaspar & GA & n.d. & n.d. & 16.8 & $48.0 \pm 11.2$ & $45.1 \pm 10.5$ \\
\hline Piedra Laja San Luis & $\mathrm{AR}$ & $6.9^{*}$ & $13.3^{*}$ & $21.2^{*}$ & $27.6 \pm 3.5$ & $71.9 *$ \\
\hline Ardósia de Canelas & PL & n.d. & n.d. & 33.4 & $23.4 \pm 4.4$ & $27.7 \pm 4.1$ \\
\hline Sauerland Schiefer & WS & n.d. & n.d. & 33.4 & $54.0 \pm 3.4$ & $50.7 \pm 5.8$ \\
\hline Pizarra de techar La Fraguiña & 120 & n.d. & n.d. & 28.2 & $60.9 \pm 5.9$ & $65.4 \pm 3.3$ \\
\hline Pizarra de techar La Fraguiña & $120-b$ & n.d. & n.d. & n.d. & $61.3 \pm 3.4$ & $69.1 \pm 10.2$ \\
\hline Pizarra de techar Valdemiguel & 150 & n.d. & n.d. & 31.0 & $54.3 \pm 4.2$ & $65.4 \pm 5.3$ \\
\hline Xisto negro de Foz Côa & $\mathrm{PO}$ & n.d. & n.d. & 3.6 & $16.4 \pm 3.4$ & $53.3 \pm 11.6$ \\
\hline Lotharheil Schiefer & LO & 30.6 (Capon)** & & & & $54.2 * *$ \\
\hline Theuma Fruchtschiefer & $\mathrm{TH}$ & $31.0(\mathrm{~mm})^{+}$ & & & & $33.5^{+}$ \\
\hline
\end{tabular}

* Data after Mosch (2008); ** data after Siegesmund and Stein (2007); ${ }^{+}$data after Natursteinwerk Theuma AG (2012)

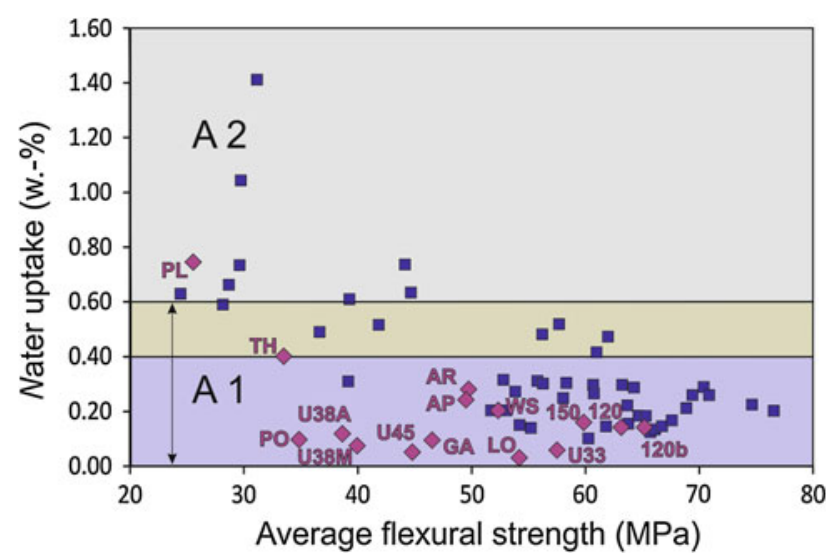

Fig. 10 Average flexural strength versus water uptake (modified after Wagner 2007) ( $L O$ data after Siegesmund and Stein 2007, TH data after Natursteinwerk Theuma AG 2012)

values of around $173 \mathrm{MPa}$ for the Lotharheil Schiefer. All these samples can be classified as hard rock (UCS values higher than $110 \mathrm{MPa}$ ), according to the classification scheme discussed in Siegesmund and Dürrast (2011), while the Theuma Fruchtschiefer belongs to the medium hard rock.

The Young's modulus, which relates the strength and the strain during the UCS measurement as described in Morales Demarco et al. (2011), ranges from 16 GPa for the
Piedra laja gris plomo (U38B) in the $y$ - and $z$-directions to $31 \mathrm{GPa}$ for the same variety in the $x$-direction. The Young's modulus values of U45 are higher in the $y$ - and $z$-direction than in the $x$-direction, but the opposite occurs in sample U38B (see Table 8).

\section{Tensile strength}

Tensile strength was measured indirectly by the Brazilian method as described by Siegesmund and Dürrast (2011). Three directions $(x, y$ and $z$ ) with respect to the foliation and lineation were analyzed for the variety Piedra laja gris plomo (U38B). In addition, the values determined by Mosch (2008) for the Piedra laja San Luis (AR) will also be discussed.

AR shows the highest values for the $z$ - and $x$-direction, with 8.0 and 21.4 MPa, respectively (Mosch 2008). However, U38B shows the highest value in the $y$-direction (15 MPa) (Table 8). The average values for both slates are within the upper and lower quartiles of the tensile strength values, which were reported for metamorphic rocks in the data set of Mosch and Siegesmund (2007).

For both commercial slate varieties the values in the $z$-direction are the lowest and the ones in the $x$-direction are the highest. This anisotropy is to be expected, as these rocks show a very well-developed slaty cleavage. 
Table 8 Mechanical properties of the samples analyzed

\begin{tabular}{|c|c|c|c|c|c|c|c|c|c|c|}
\hline \multirow[t]{2}{*}{ Trade name } & \multirow[t]{2}{*}{ ID } & \multicolumn{3}{|c|}{ Uniaxial compressive strength (MPa) } & \multicolumn{3}{|c|}{ Young's modulus (GPa) } & \multicolumn{3}{|c|}{ Tensile strength (MPa) } \\
\hline & & $x$ & $y$ & $z$ & $x$ & $y$ & $z$ & $x$ & $y$ & $z$ \\
\hline Piedra Laja Negra, Rufo Hnos & $\mathrm{U} 45$ & $191 \pm 6$ & $116 \pm 19$ & $152 \pm 23$ & $17 \pm 4$ & $18 \pm 7$ & $26 \pm 6$ & n.d. & n.d. & n.d. \\
\hline Piedra laja gris plomo & U38B & $153 \pm 31$ & $130 \pm 29$ & $126 \pm 24$ & $31 \pm 10$ & $16 \pm 11$ & $16 \pm 6$ & $19 \pm 4$ & $15 \pm 3$ & $6 \pm 2$ \\
\hline Ardósia de Canelas & PL & & $159.1 *$ & & n.d. & n.d. & n.d. & n.d. & n.d. & n.d. \\
\hline Xisto negro de Foz Côa & $\mathrm{PO}$ & & $144.0^{+}$ & & n.d. & n.d. & n.d. & n.d. & n.d. & n.d. \\
\hline Piedra laja San Luis & $\mathrm{AR}$ & $215^{*}$ & $143^{*}$ & $159 *$ & n.d. & n.d. & n.d. & $21.4^{*}$ & $10.7 *$ & $8.0 *$ \\
\hline Lotharheil Schiefer & LO & & $172.6^{* *}$ & & n.d. & n.d. & n.d. & n.d. & n.d. & n.d. \\
\hline Theuma Fruchtschiefer & $\mathrm{TH}$ & & $89.8^{++}$ & & n.d. & n.d. & n.d. & n.d. & n.d. & n.d. \\
\hline
\end{tabular}

* Data after Mosch (2008); ** data after Siegesmund and Stein (2007)

\section{Abrasion strength}

The relevance of the abrasion strength in slates, and generally in all natural stones, is mainly related to their use as floor tiles and staircases. Floor tiles are exposed to grinding forces produced by footsteps and walking, and the abrasion strength test is a method that measures the resistance of a rock against these forces (see Siegesmund and Dürrast 2011).

The abrasion strength was performed using a Böhme abrasion testing machine as described in the DIN 52108 (1988). The abrasion strength of the $x y$-plane (parallel to the foliation) was measured for all samples analyzed, since this surface is generally used for floor cladding. In the varieties Piedra laja negra Rufo Hnos, Piedra laja gris plomo and Piedra laja San Luís the $x z$ - and yz-planes were also measured. The results are shown in Table 7. The values measured show a large variation, between 3.6 and $33.4 \mathrm{~cm}^{3} / 50 \mathrm{~cm}^{2}$, for the Xisto negro de Foz Côa (PO) and the Sauerland Schiefer (WS), respectively. The samples that show lower abrasion strength, and therefore higher values of volume lost, between 28.2 and $33.4 \mathrm{~cm}^{3} / 50 \mathrm{~cm}^{2}$, are the slates (PL, WS, 120, 150). These rocks show the highest proportion of normative phyllosilicates, between 61 and $68 \%$. The highest abrasion strength values exhibited by the samples with the lowest proportion of normative phyllosilicates (between 22 and $30 \%$ ) are samples PO and U38D, respectively. Therefore, a negative correlation between abrasion strength and normative phyllosilicate proportion is evident when this property is measured parallel to the foliation.

In the directions perpendicular to the foliation this correlation is not so clear. Further investigation should be done to analyze the impact of structural elements in the abrasion strength of slates.

Based on SEM investigations Strohmeyer (2003) found that the abrasion strength for highly anisotropic rocks is lower parallel to the foliation, although the total anisotropy is less pronounced compared with the flexural strength or tensile strength. For example, the abrasion resistance for the slate from Argentina is between 7 and $21 \mathrm{~cm}^{3} / 50 \mathrm{~cm}^{2}$ (67\% anisotropy). In the abrasion test the minerals hardly show scratching or grinding marks. The minerals apparently suffer crystal fragmentation, which ultimately leads to the disintegration of the whole mineral assembly by fabric loosening.

Considering their abrasion strength behavior, slates do not form a homogeneous group when compared to granitoids or quartzites (see Siegesmund and Dürrast 2011). The highest abrasion strength values measured for the slates (e.g., PO, U38D) allow them to be grouped between the most resistant dimensional rocks, which are the dolerites, e.g., the variety Absolute Black with an abrasion resistance of $2.2 \mathrm{~cm}^{3} / 50 \mathrm{~cm}^{2}$ (Morales Demarco et al. 2011). The lower abrasion strengths measured in the analyzed slates (e.g., PL and WS) makes them similar to the group containing clay shale, porous limestone and sandstone (Siegesmund and Dürrast 2011).

\section{Thermal and hydric expansion and freeze-thaw tests}

The influence of external environmental conditions (weather, anthropologic factors) is important when considering the use of slate as a dimensional stone. High resistance is usually expected in slate, regardless of their application as roofing or façade cladding or in garden and landscaping. The causes of weathering result from thermal factors, such as changes in temperature and also the impact of snow and rain. To assess these relationships, thermal, hydric and freeze-thaw analyses were performed.

\section{Thermal expansion}

Changes in temperature can result in volume expansion or contraction of a stone. Even if the temperature changes are not large, the repeated heating and cooling of stones could 
Table 9 Thermal and hydric expansion of the analyzed samples

\begin{tabular}{|c|c|c|c|c|c|c|c|}
\hline \multirow[t]{2}{*}{ Trade name } & \multirow[t]{2}{*}{ Sample } & \multicolumn{3}{|c|}{ Hydric expansion $(\mathrm{mm} / \mathrm{m})$} & \multicolumn{3}{|c|}{ Thermal expansion coefficient $\alpha\left(\times 10^{-6} \mathrm{~K}^{-1}\right)$} \\
\hline & & $x$ & $y$ & $z$ & $x$ & $y$ & $z$ \\
\hline Piedra laja negra, Caorsi Hnos & $\mathrm{U} 33$ & 0.08 & 0.03 & 0.54 & 9.0 & 9.6 & 11.7 \\
\hline Piedra laja negra, Rufo Hnos & $\mathrm{U} 45$ & 0.02 & 0.02 & 0.18 & 9.4 & 9.7 & 11.0 \\
\hline Piedra laja ocre & U38A & 0.01 & 0.00 & 0.51 & 9.4 & 9.8 & 10.8 \\
\hline Piedra laja gris plomo & U38B & 0.03 & 0.01 & 0.30 & 10.3 & 10.0 & 13.3 \\
\hline Piedra laja verde oscura & $\mathrm{U} 38 \mathrm{C}$ & 0.02 & 0.07 & 0.25 & 10.1 & 8.8 & 10.3 \\
\hline Piedra laja verde clara & U38D & 0.07 & 0.04 & 0.20 & 9.6 & 9.4 & 10.6 \\
\hline Piedra laja verde clara "macho" & U38M & 0.02 & 0.06 & 0.55 & 9.6 & 10.2 & 11.1 \\
\hline Ardósia Apiúna & $\mathrm{AP}$ & 0.47 & 0.79 & 1.82 & 8.6 & 9.0 & 8.5 \\
\hline Ardósia Gaspar & GA & 0.10 & 0.10 & 0.92 & 8.6 & 9.3 & 10.3 \\
\hline Piedra Laja San Luis & $\mathrm{AR}$ & 0.07 & 0.03 & 1.18 & $9.5^{*}$ & $9.9^{*}$ & $11.8^{*}$ \\
\hline Ardosia de Canelas & PL & 0.17 & 0.35 & 6.75 & 9.4 & 9.3 & 7.0 \\
\hline Sauerland Schiefer & WS & 0.03 & 0.04 & 2.68 & 8.5 & 9.1 & 10.7 \\
\hline Pizarra de techar La Fraguiña & 120 & 0.01 & 0.01 & 1.32 & 9.1 & 10.0 & 12.3 \\
\hline Pizarra de techar Valdemiguel & 150 & 0.01 & 0.01 & 1.32 & 8.9 & 9.2 & 11.7 \\
\hline Xisto negro de Foz Côa & $\mathrm{PO}$ & 0.03 & 0.09 & 0.16 & 9.5 & 9.7 & 9.8 \\
\hline Lotharheil Schiefer & LO & n.d. & 0.09 & 0.13 & n.d. & 10.1 & 10.4 \\
\hline Theuma Fruchtschiefer & $\mathrm{TH}$ & $0.15^{\#}$ & n.d. & $1.45^{\#}$ & $9.8^{+}$ & $9.3^{+}$ & $12.1^{+}$ \\
\hline
\end{tabular}

* Data after Mosch (2008); ${ }^{\#}$ data after Weiss et al. (2004); ${ }^{+}$data after Siegesmund and Dürrast (2011)

produce a significant deterioration over time. This holds true especially in heterogeneous rocks, e.g., with respect to the rock fabrics and the mineralogical composition.

Thermal expansion measurements of the slates were performed using a dilatometer (for details see Strohmeyer 2003 or Koch and Siegesmund 2004). In order to simulate temperature changes comparable to those observed under natural conditions for building or ornamental stones, the temperature cycles were fixed at $90{ }^{\circ} \mathrm{C}$. The thermal expansion was measured in three directions: one perpendicular to the foliation ( $z$-direction) and two parallel to it ( $x$ - and $y$-direction). The values measured for thermal expansion (Table 9) vary from 7.0 to $13.3 \times 10^{-6} \mathrm{~K}^{-1}$ for the Ardósia de Canelas (PL) and the Piedra laja gris plomo (U38B), respectively.

In the $x$ - and $y$-direction the values are generally lower than in the $z$-direction (perpendicular to the slaty cleavage), between 8.5 and $10.3 \times 10^{-6} \mathrm{~K}^{-1}$. This anisotropy is related to the preferred orientation of the phyllosilicates in these rocks. In muscovite, for example, the lowest thermal expansion coefficient is parallel to the crystallographic $a$-axis and the highest parallel to the $c$-axes: 9.9 and $13.8 \times 10^{-6} \mathrm{~K}^{-1}$, respectively, (Fei 1995).

Exceptions are the Ardósia Apiúna (AP) and Ardósia de Canelas (PL). AP is more or less isotropic when comparing the three measured directions (Table 9), while PL exhibits anisotropy of around $25 \%$. Although muscovite crystals are oriented parallel to the slaty cleavage in the Ardósia Apiúna (AP), biotite is randomly distributed and it may be responsible for the more or less isotropic behavior. The anisotropic behavior of PL can be explained by the chloritoid porphyroblasts, which are oriented with their long axes perpendicular, transversal or parallel to the foliation. Ivaldi et al. (1988) found that chloritoid is an anisotropic mineral with respect to thermal properties.

The dolomitic slates show slightly higher values perpendicular to the foliation than the pelitic and semipelitic slates. This could be related to a higher thermal expansion coefficient in dolomite, superposing the effect of the oriented phyllosilicates in the whole rock behavior. Dolomite shows thermal expansion anisotropy, being higher parallel to the $c$-axis than parallel to the $a$-axes (Reeder and Markgraf 1986; Weiss et al. 2004).

To summarize, the values given in Table 9 are in agreement with those compiled by Siegesmund and Dürrast (2011) for slates. According to these authors, their thermal expansion varies between 9.3 and $12.8 \times 10^{-6} \mathrm{~K}^{-1}$, showing also higher values in the $z$-direction.

The residual strain, which is the permanent length change of a sample after the thermal expansion measurement, is between 0.02 and $-0.30 \mathrm{~mm} / \mathrm{m}$. The lowest values are observed in the Piedra laja negra Caorsi Hnos (U33) and Ardósia de Canelas (PL) and the highest in the Ardósia Apiúna (AP) and Theuma Fruchtschiefer (TH). The Theuma Fruchtschiefer contains predominantly quartz and mica and shows high thermal expansion coefficients. These minerals also have a high volume expansion coefficient. Feldspar (with a low volume expansion coefficient) is 

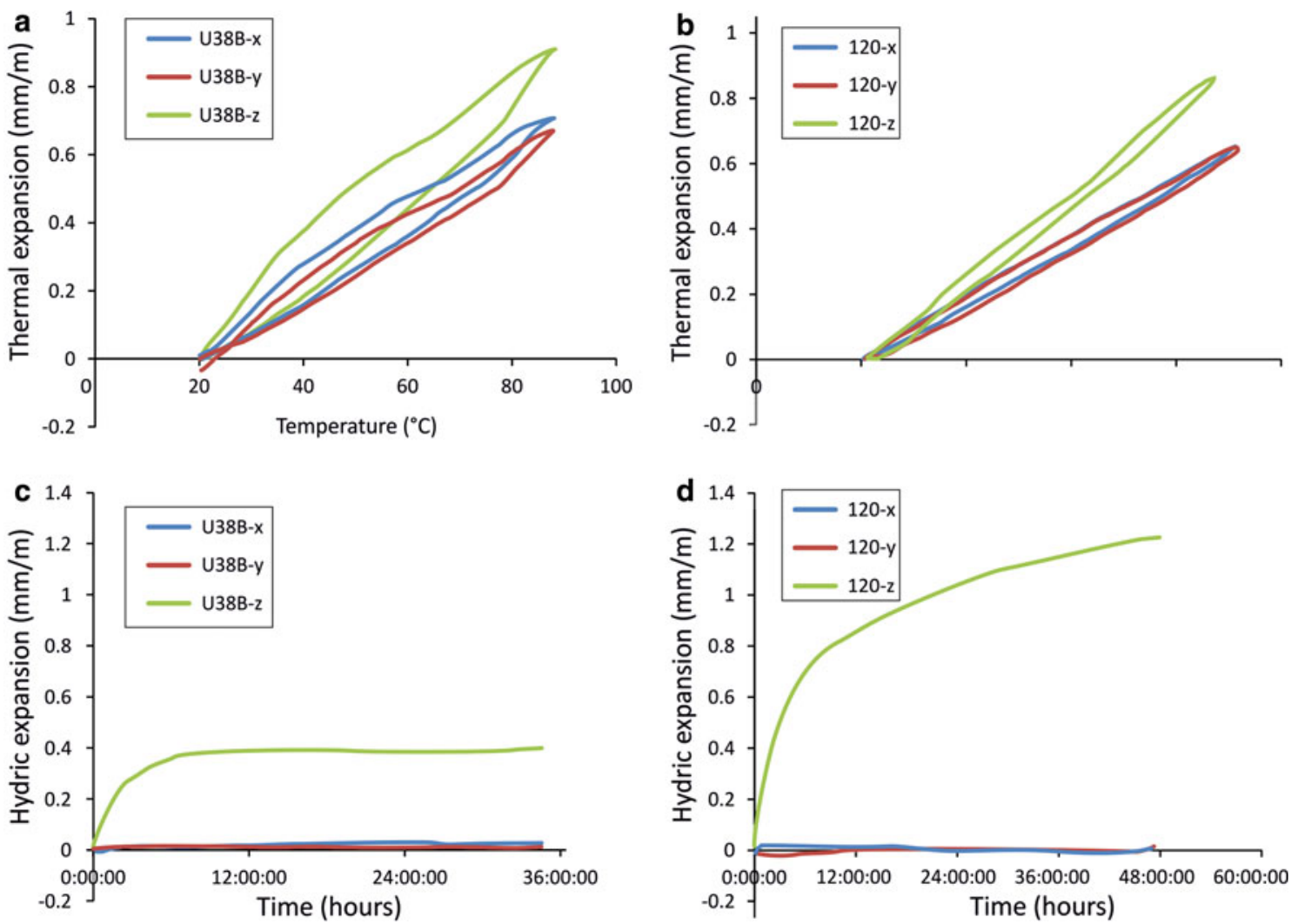

Fig. 11 Thermal expansion diagrams for: a Piedra laja gris plomo (U38B) and b Pizarra de techar La Fraguiña (120). Hydric expansion diagrams for: c Piedra laja gris plomo (U38B) and d Pizarra de techar La Fraguiña (120)

lacking. The thermal expansion curve of the Theuma Fruchtschiefer is also characterized by a dehydration reaction, which is most pronounced perpendicular to the foliation (residual strain $-0.3 \mathrm{~mm} / \mathrm{m}$ at $20{ }^{\circ} \mathrm{C}$ ) and almost negligible parallel to the foliation (Weiss et al. 2004).

\section{Hydric expansion}

The hydric expansion is a measurement of the dilatation of a rock when completely submerged in water (Siegesmund and Dürrast 2011). The weathering behavior of dimensional stones is, for these authors, strongly influenced by the processes involved in hydric expansion together with the thermal expansion.

This property was also measured using the $x, y$ and $z$ coordinate system. The values obtained (Table 9 and Fig. 11) vary between 0.0 in the $y$-direction for the Piedra laja ocre (U38A) and $6.75 \mathrm{~mm} / \mathrm{m}$ in $z$-direction for the Ardósia de Canelas (PL). The range in $x$ - and $y$-direction is between 0.00 and $0.79 \mathrm{~mm} / \mathrm{m}$ and in the $z$-direction is between 0.13 and $6.75 \mathrm{~mm} / \mathrm{m}$. As for the thermal expansion this anisotropy is related to the preferred orientation of the phyllosilicates, the higher proportion of phyllosilicates in a slate leads to a higher hydric expansion.
In comparison to other dimensional stones, slates show a wider range of hydric expansion, especially in the case of pelitic and semipelitic slates (Fig. 12). The values of hygric expansion shown by the dolomitic slates are comparable to those of marble, limestone and sandstone with the lowest hygric expansion (type I, measurements after Hockmann and Kessler 1950).

\section{Freeze resistance}

The freeze resistance is a very important property of dimensional stones, especially the slates. When the water uptake is higher than $0.6 \mathrm{wt} \%$, the safeness against freeze has to be determined in accordance with the DIN EN 12326:1 (2004).

In order to know the weathering stability of the selected commercial slates in cold climates, a total of 100 freezethaw cycles were carried out. The weight of the samples and the Young's modulus were measured every four cycles.

The mass variation for all the slates considered is very low, as shown in Fig. 13, between an increase of $0.01 \%$ in the Ardósia Apiúna (AP), which can be considered an experimental error, and a decrease of $0.19 \mathrm{wt} \%$ measured 
Fig. 12 Hydric expansion of dolomitic, pelitic and semipelitic slates in comparison to different rock types (modified after Siegesmund and Dürrast 2011)

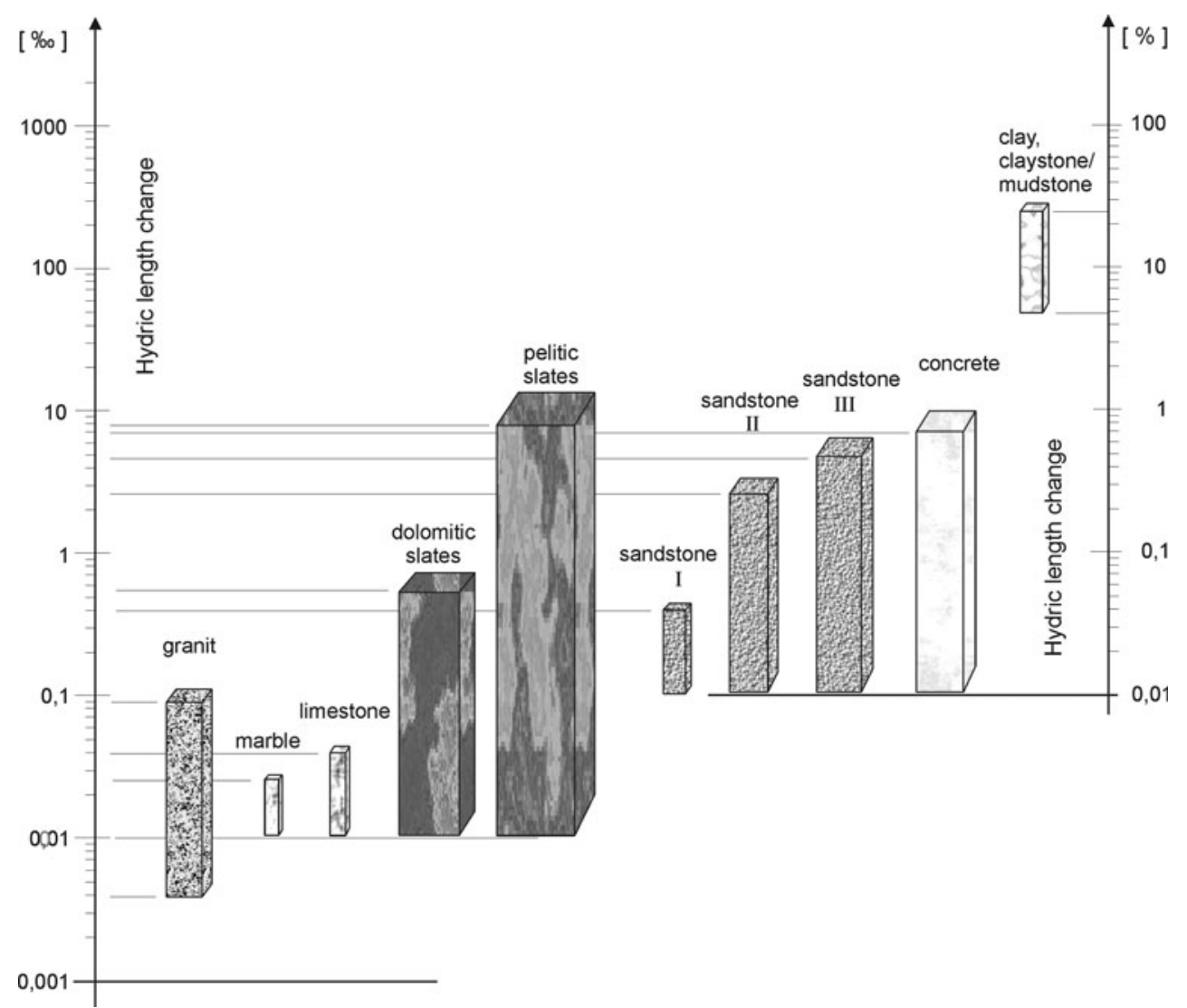

in the Ardósia de Canelas (PL). The samples that showed a higher weight loss (between 0.12 and $0.19 \mathrm{wt} \%$ ) are in increasing order the Piedra laja verde oscura (U38C), Piedra laja verde clara "macho" (U38M) and the Ardósia de Canelas (PL). In the first two samples the loss of weight is determined by the dissolution of dolomite on the sample surface. This phenomenon is also visible in the other dolomitic slates. Pyrite present as veins and disseminated shows an incipient oxidation, but no color spots develop surrounding them. A variation in color is noticed for this group of slates in the sawed surfaces, but no change is perceived along the foliation surfaces.

In the Ardósia de Canelas an opening of the foliation surface is noted, as well as orange and white spots due to the oxidation of pyrite and precipitation of salts (probably gypsum), respectively. All these processes can explain the loss of weight in the freeze-thaw experiment. The values determined for all slates studied are very low compared to those measured by Rüdrich et al. (2011) for the Habichtswald tuff but similar to those of the Kuaker limestone, Lobejuen porphyry and Knaupsholz granite.

The values for the Young's modulus range from 77.7 to $120.7 \mathrm{kN} / \mathrm{mm}^{2}$ in the Ardósia Apiúna (AP) and in the Piedra laja verde oscura (U38C), respectively (Fig. 13). The variation of the Young's modulus ranges between an increase of up to $10.81 \%$ in the Ardósia de Canelas (PL) and a decrease of up to $24.86 \%$ in the Ardósia Apiúna (AP).

\section{Deposit characterization}

Regional mining districts

The dolomitic slate deposits in Uruguay are located $25 \mathrm{~km}$ north of the locality of Pan de Azúcar and about $100 \mathrm{~km}$ from Montevideo. There are two main dolomitic slate mining districts in the region (Fig. 14). The northern one is located at the source of the Arroyo Minas Viejas and is accessible from Route 60 (Arroyo Minas Viejas district: AMVD). The southern district is located at the source of the Arroyo Mataojo and accessible from Route 81 (Arroyo Mataojo district: AMD).

The dolomitic slate deposits are located in the eastern limb of a regional fold, known as the "Road 81 syncline", and are related to a second deformation phase. The mining districts are situated in the center of the Minas Viejas Association and bound to the east and west with phyllites and metabasalts. A metagabbro body crops out in the western boundary of the northern district (AMVD).

A minor slate mining district is represented by two quarries where the variety Piedra laja rosada con gris 

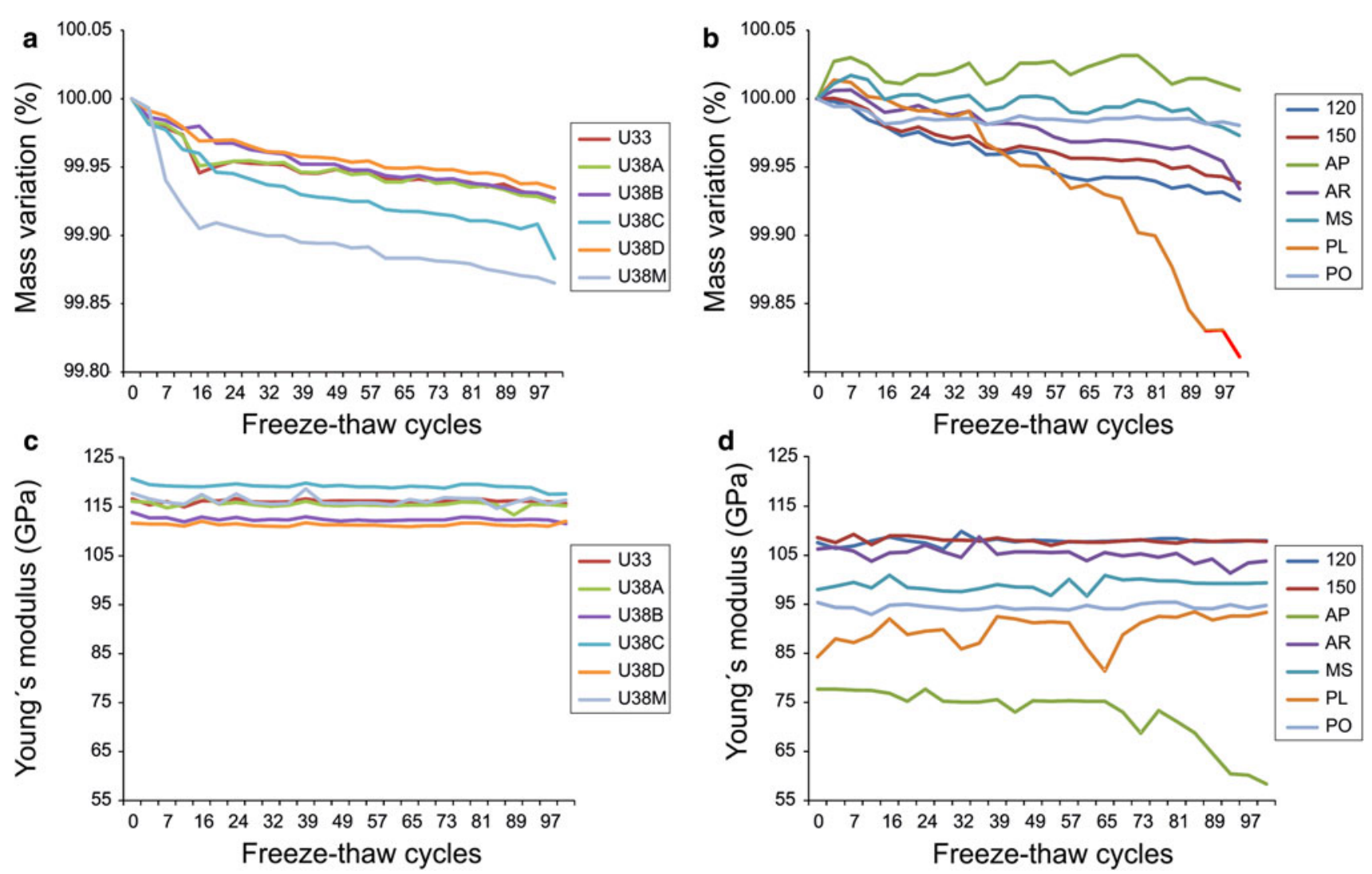

Fig. 13 Mass variation after 100 freeze-thaw cycles for: a commercial dolomitic slates, b commercial pelitic and semipelitic slates. Young's modulus variation after 100 freeze-thaw cycles for: $\mathbf{c}$ commercial dolomitic slates, $\mathbf{d}$ commercial pelitic and semipelitic slates

(UY-106) was mined. This district is located $1 \mathrm{~km}$ east of the AMVD but in another lithological association, known as the Zanja del Tigre-Cuchilla Alvariza Association. Another slate mining district is located in the Rocha department, represented by the slate variety Piedra laja Rocha (UY-108) and belonging to the lithological unit of the Rocha Group.

The AMVD is $3 \mathrm{~km}$ long in a NE-SW direction and $300 \mathrm{~m}$ wide. This district is characterized by the presence of dolomitic slates showing light and dark green, red, gray and bluish gray colors. A total of 18 quarries of different sizes are located in this district, in which just four are being actively mined. About $3 \mathrm{~km}$ to the southwest the Arroyo Mataojo district is located. It extends further to the southwest for about $4 \mathrm{~km}$ and is $500 \mathrm{~m}$ wide. Five quarries of dark gray and black dolomitic slates are found in this district, but at the present only one is active.

The dolomitic slate deposits are characterized by their elongated shape parallel to the $S_{0-1}$ foliation, which makes their mining similar to the quarrying of dikes (e.g., dolerite). Since the slate deposits are related to strata with a defined composition, they can be defined as stratabound deposits in the sense of Canavan (1973). To define a dolomitic slate deposit is necessary not only to find the characteristic mineral composition, but also an ensemble of structural factors that will allow their profitable mining (e.g., parallelism between $\mathrm{S}_{0-1}$ and $\mathrm{S}_{2}$, absence of highly folded sectors).

The mining districts have a width of 300-500 m, however, the individual slate bodies can range between 8 and $50 \mathrm{~m}$ in width, but generally most show widths of around $12 \mathrm{~m}$. Their length varies between 60 and $150 \mathrm{~m}$ and the current exploitation depth ranges between 6 and $15 \mathrm{~m}$. The northwest walls tend to be unstable, due to the fact that the foliation dips around $80^{\circ}$ to the northwest. In active quarries those walls are controlled daily to prevent collapse.

The dolomitic slates deposits in Uruguay occur in the greenschist facies volcano-sedimentary Lavalleja Group, which forms part of the Dom Feliciano Belt in Uruguay. These deposits are, therefore, controlled by the regional structures that affect all the lithologies comprising this group.

\section{Structural framework and controlling factors of the deposit}

The structural framework of the studied area was investigated in detail by Midot (1984), who recognized three phases of 
Fig. 14 Location of dolomitic slate mining districts in Uruguay

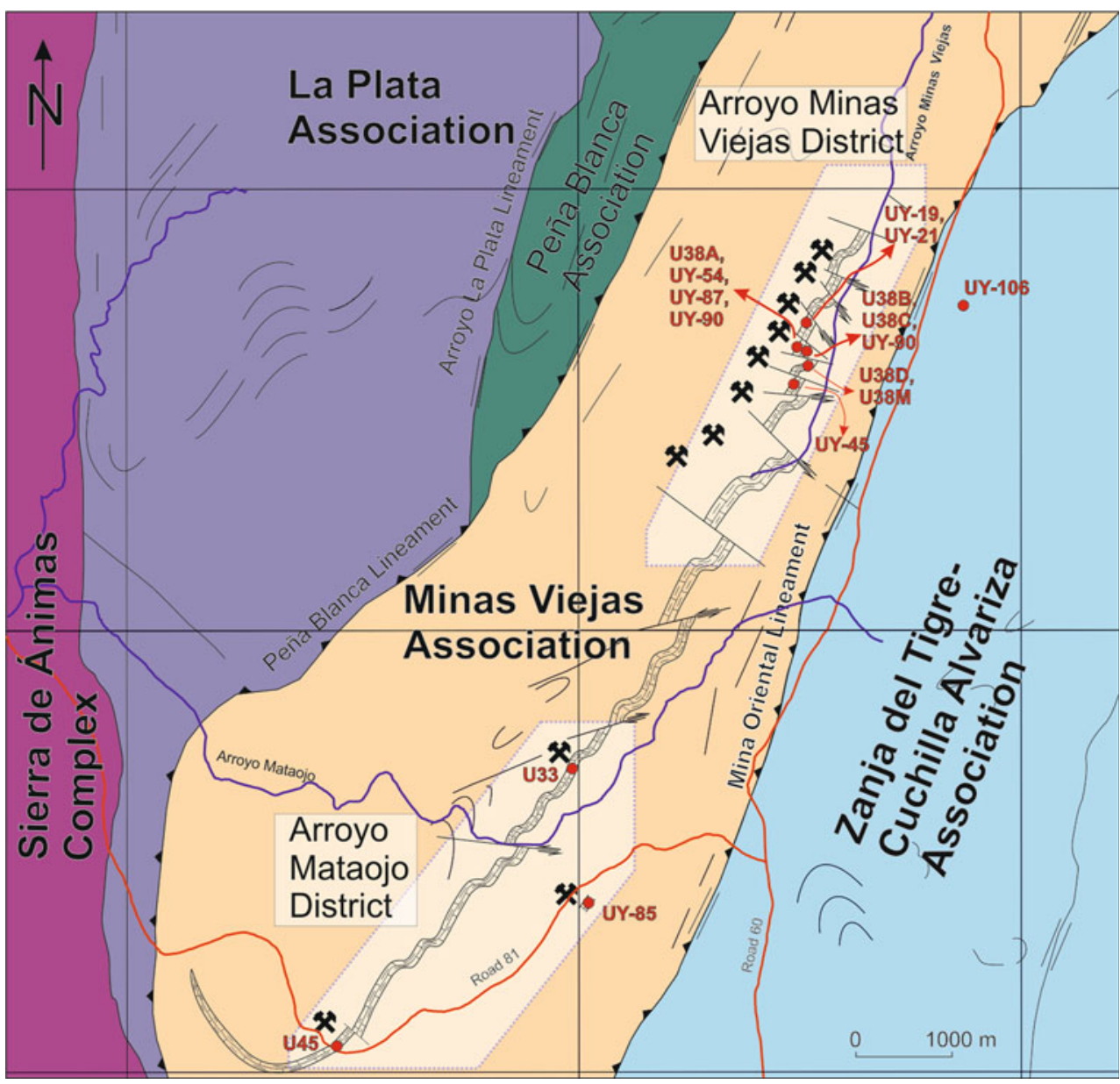

deformation. The first phase $\left(D_{1}\right)$ generated the foliation $S_{1}$ with the oriented recrystallization of the phyllosilicates and the stretching of other minerals such as quartz, feldspar and dolomite. $\mathrm{S}_{1}$ is described as an axial plane foliation resulting from isoclinal folding. Due to transposition, the primary foliation of these rocks $\left(S_{0}\right)$ is similar to the foliation $S_{1}$. Midot (1984) defines these foliations as $S_{0-1}$, because with few exceptions it is very difficult to distinguish them both (e.g., in intrafolial microfolds). The $\mathrm{S}_{0-1}$ is the slaty cleavage that characterizes the dolomitic slates and creates the condition for their extraction. The cleavage dips between $70^{\circ}$ and $90^{\circ}$ to the NW with a NNE strike (Figs. 15, 16).

Boudinage of the carbonate and quartzite layers interlayered in the dolomitic slate body also belongs to the $\mathrm{D}_{1}$ (Fig. 17a). Generally, the boudins are between 2 and $5 \mathrm{~cm}$ thick, and show extension in two directions perpendicular to one another, which produce irregularities in the surface of the slate. These boudins are more frequent in the AMVD, and thus create problems for the extraction of the mined slates in this district. Another structural element related to this $D_{1}$ is the mineral lineation $L_{1}$, as evidenced by the alignment of fine-grained chlorite and sericite aggregates in the foliation plane.
The second deformation phase defined by Midot (1984) is a folding event, which generated folds of millimeters to kilometric in magnitude. The last ones are the most frequently recognized, e.g., the Road 81 syncline, which is one of the major folds acknowledged in the area. Midot (1984) described the structures developed in the dolomitic slates in this phase as fracture cleavage, which is the old term for disjunctive foliation or cleavage. A spaced cleavage is characterized by the presence of microlithons between the cleavage domains (Passchier and Trouw 1996). Disjunctive foliation can evolve to "strain-slip schistosity" or, using a term with no genetic connotations: crenulation cleavage (Passchier and Trouw 1996). This disjunctive foliation or crenulation cleavage is an axial plane foliation $\left(S_{2}\right)$ that intensely deforms the $S_{0-1}$, when the angle between both foliations is near $90^{\circ}$ (in the hinges of the folds of $\mathrm{D}_{2}$ ). When the angle between both foliations is small, the $S_{0-1}$ surface is not affected and $S_{2}$ is parallel to $S_{0-1}$. There is no evidence of recrystallization associated to this deformation phase $\mathrm{D}_{1}$.

Midot (1984) described the $\mathrm{D}_{2}$ microfolds in the slates as being of two types: kink (or chevron folds) and others with more rounded and open hinges. The kink folds are asymmetric and they negatively affect the mining of the 

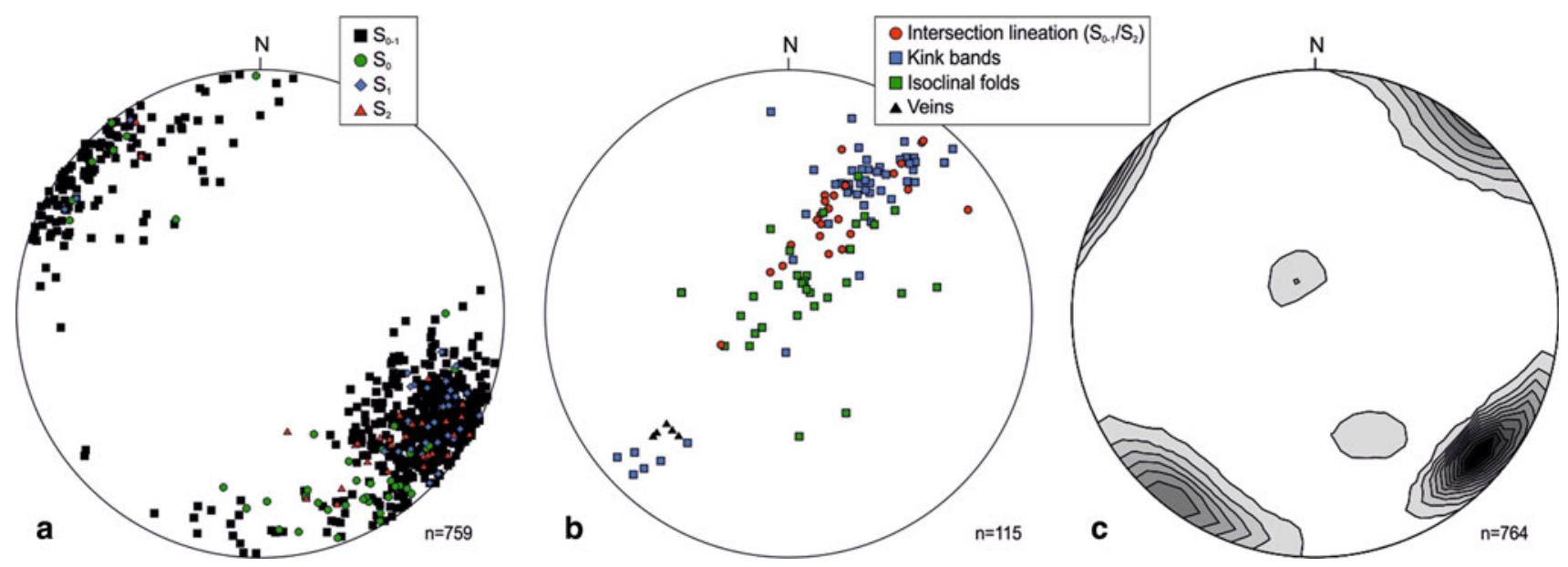

Fig. 15 Stereonets showing the structural elements in the dolomitic slate deposits (lower hemisphere): a foliations; b fold axes and lineations; c joint sets $(1,2, \ldots, 13$ multiples of random distribution)

deposit, only when their amplitude is larger than $2.5 \mathrm{~cm}$ (Fig. 17b, c). However, these kink folds generally have smaller amplitudes (on the order of $0.5 \mathrm{~cm}$ ) and larger wavelengths $(>4 \mathrm{~m})$, and therefore they do not affect the extraction of the slates.

The lineation $L_{2}$ develops as the foliations $S_{0-1}$ and $S_{2}$ intersect and is parallel to the fold axes. The folds belonging to the second type are decimeters in size, but composed of a multitude of millimeter-sized microfolds that generate an embossing of the $\mathrm{S}_{0-1}$ surface. The axes of these microfolds produce a microfolding or intersection lineation, also called $\mathrm{L}_{2}$ by Midot (1984).

Another element that negatively affects the quality of the mined slate in the deposits is the foliation $\mathrm{S}_{2}$. When the angle to the foliation $\mathrm{S}_{0-1}$ is less than $10^{\circ}$, scales will develop on the $\mathrm{S}_{0-1}$ surface. Also when the angle between $\mathrm{S}_{0-1}$ and $\mathrm{S}_{2}$ is greater than $30^{\circ}$, the mining will be negatively affected because the slate does not split as easily through the $\mathrm{S}_{0-1}$ foliation.

Structures of the last deformation phase $\left(\mathrm{D}_{3}\right)$ are only locally found near areas with high brittle deformation. These structures represent a second disjunctive foliation $\left(\mathrm{S}_{3}\right)$ that deforms both $\mathrm{S}_{2}$ and $\mathrm{S}_{0-1}$. The $\mathrm{S}_{3}$ is vertical and is sometimes accompanied by inverse fractures dipping to the west. The frequency and intensity of $\mathrm{S}_{3}$ determines in some cases the length of the deposits, since this $S_{3}$ foliation frequently crosscuts them.

To summarize, all these structural factors control the following aspects of the deposits:

(a) width of the deposits, due to the occurrence of strongly folded sectors that progressively limit the mining on both lateral walls of a quarry;

(b) length of the deposits, which determines either the occurrence of E-W strike-slip faults (dextral and sinistral) and/or boudins affecting decameter-scaled dolomitic slate bodies, both elements disrupting the continuity of these bodies; (c) depth of the mining, controlled by the dip angle of the foliation $\mathrm{S}_{0-1}$, which determines the stability of the northwestern quarry wall.

To investigate the relationship between geochemistry of the different dolomitic slates and their mechanical response to the deformation phases, several samples have been analyzed by XRF (Tables 10,11). Samples were collected from quarry G119 (the commercial varieties U38B and U38C) and in quarry G120 (U38D and U38M), located $10 \mathrm{~m}$ to the southeast from the first quarry. The samples U38B, U38C and U38D show a very good fissility along the foliation $\mathrm{S}_{0-1}$, whereas the fissility is very poor in sample U38M. This last sample is characterized by the abundance of isoclinal folds and its inhomogeneity, defined by the intercalation of layers with coarse-grained quartz and pyrite grains, and layers with similar composition and fabric as U38D. When comparing the geochemistry of these three rocks, the main difference is in the composition of $\mathrm{U} 38 \mathrm{~B}$, which shows more $\mathrm{SiO}_{2}$ and less $\mathrm{MgO}, \mathrm{CaO}$ and $\mathrm{CO}_{2}$ than the other three varieties. In the case of U38M it is highly probable that the coarser grained layers affect the rheology of the rock, producing more folds and a well-developed $\mathrm{S}_{2}$.

Another example is given by quarry (G115) where the samples (U38A and UY-54) are not affected by folds, when compared with a sample located $5 \mathrm{~m}$ southeast from the quarry wall and strongly folded (UY-87). These three rocks do not show any significant differences in their geochemistry or petrography, but they do show variations in the quality as a marketable slate.

The structural development in the dolomitic slate body (e.g., folds, boudins, faults) appears to be controlled by the preexisting rock fabric and the deformation regime. The joint systems that developed later do not necessarily affect the mining of the slates. They are generally orthogonal to one another (Fig. 17f) and their frequencies allow the acquisition 
a

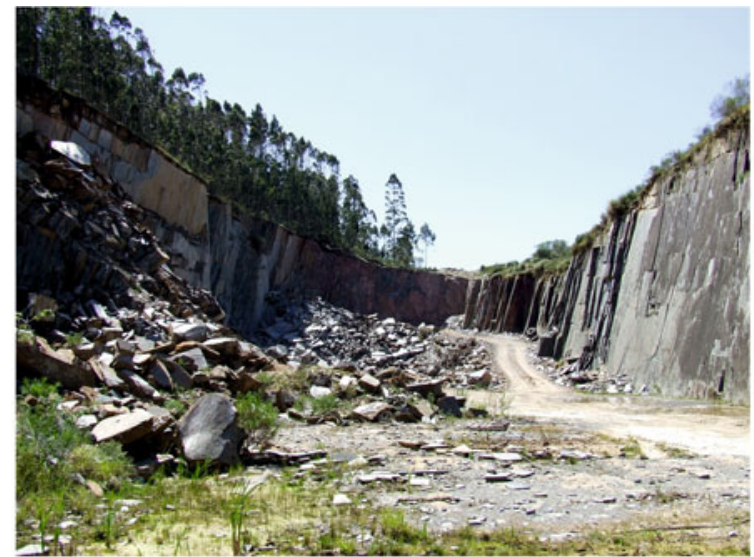

b

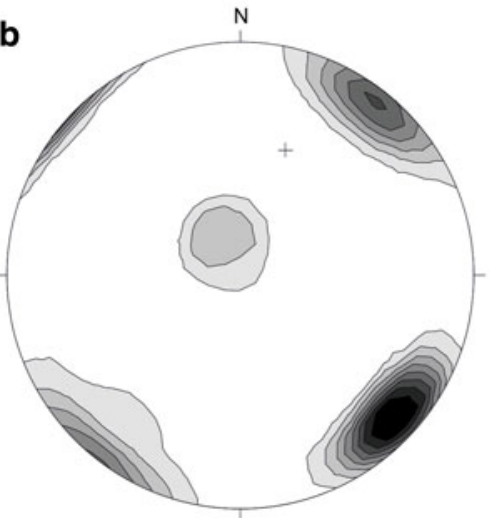

$\mathrm{N}=222$

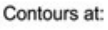

$1.00, \quad 2.00, \quad 3.00, \quad 4.00$

$5.00, \quad 6.00, \quad 7.00, \quad 8.00$

9.00

(Multiples of random distribution

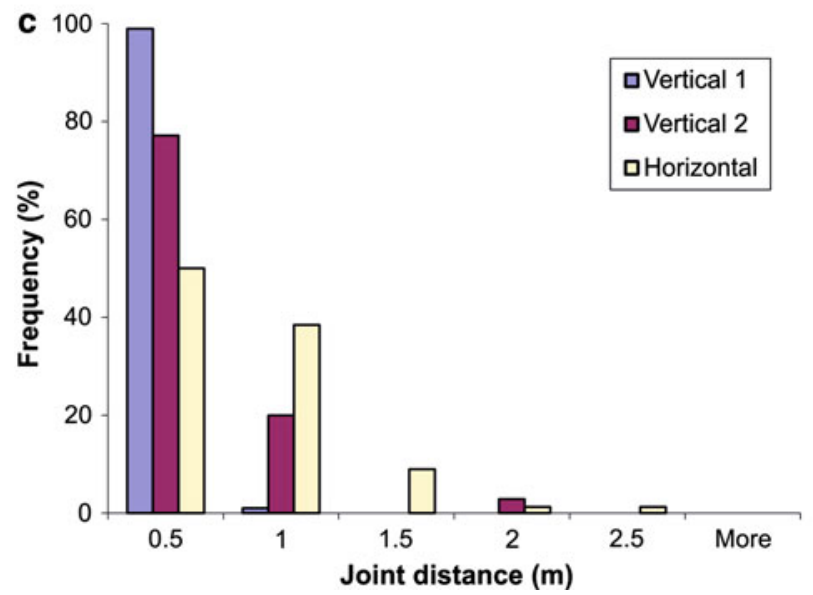

Fig. 16 a Joint sets in the black dolomitic slate (U33, Caorsi Hnos Quarry). b Stereonet depicting the three main joint sets. c Histogram showing joint set distribution

of sufficiently large blocks (up to $50 \mathrm{~cm}$ perpendicular to the foliation and up to $4 \mathrm{~m}^{2}$ parallel to the foliation).

\section{Mining techniques in Uruguay}

The techniques used in Uruguay today for exploiting dolomitic slates do not include the most modern ones, such as the diamond wire technique. Instead small explosive charges are used to remove relatively large blocks (up to $4 \mathrm{~m}^{3}$ ). The direction of mining is perpendicular to the foliation and always from above. These blocks are reduced to smaller blocks with a pneumatic hammer in the quarry and then transported to cutting shed (Fig. 18a, b). There the blocks are cut to preset dimensions (e.g., $30 \times 40 \mathrm{~cm}$ ) and afterwards split by hand to a desired thickness (generally 16 mm) (Fig. 18c, d).

\section{Economic aspects}

Estimation/evaluation of the deposits

Dolomitic slate deposits are characterized by their elongated shape and relatively small sizes. The three spatial dimensions (width, length and depth) are limited by the structural controlling elements that define the geometrical distribution of the lithology of interest. No data of continuity with depth exists for the dolomitic slate deposit, however, based on the vertical exposure of the dolomitic slate body, it probably continues for at least $50 \mathrm{~m}$ in depth. This is also the maximum depth for mining without taking the safety precautions into consideration, especially in cases where the deposits are very narrow. The possible occurrence of inverse fractures from the deformation $\mathrm{D}_{3}$ (Midot 1984) could interrupt the continuity of the deposit at depth.

A typical dolomitic slate deposit from the northern district was evaluated for its economic potential, whereby the results can be extrapolated to the other deposits in both mining districts. The chosen deposit, composed of quarries G118 and G119, is bound to the northeast and south by strike-slip faults, having a length of $400 \mathrm{~m}$. These strike-slip faults are recognizable in aerial photos and satellite images. In the field small valleys are recognizable in the deposit boundaries, which indicate the presence of faults. Furthermore, exploratory quarries have been opened near these faults and the mining was discontinued due to intensive folding (related to the major regional folds) or a very well-developed $S_{2}$ foliation (with an angle to $S_{0-1}$ of $30^{\circ}$ ), or both. The deposit width is $12 \mathrm{~m}$, being bounded by folded zones to the northwest and southeast, which produces a loss of fissility and the mining there becomes unprofitable. The raw blocks extracted from these folded zones are not suitable for the production of marketable slabs with at least $30 \mathrm{~cm}$ in length.

The deposit is separated by a fault along the middle of its length, which leads to a cessation of mining at about $30 \mathrm{~m}$. The lithologies are the same on both sides of the fault, as well as the dip and direction of the main foliation. Both sectors of the deposit have been successfully mined; the northern one corresponds to the inactive quarry G118, and the southern one to the active quarry G119.

Two color varieties are available in this deposit: Piedra laja gris plomo (U38B) cropping out as a 5-m "layer" on the 

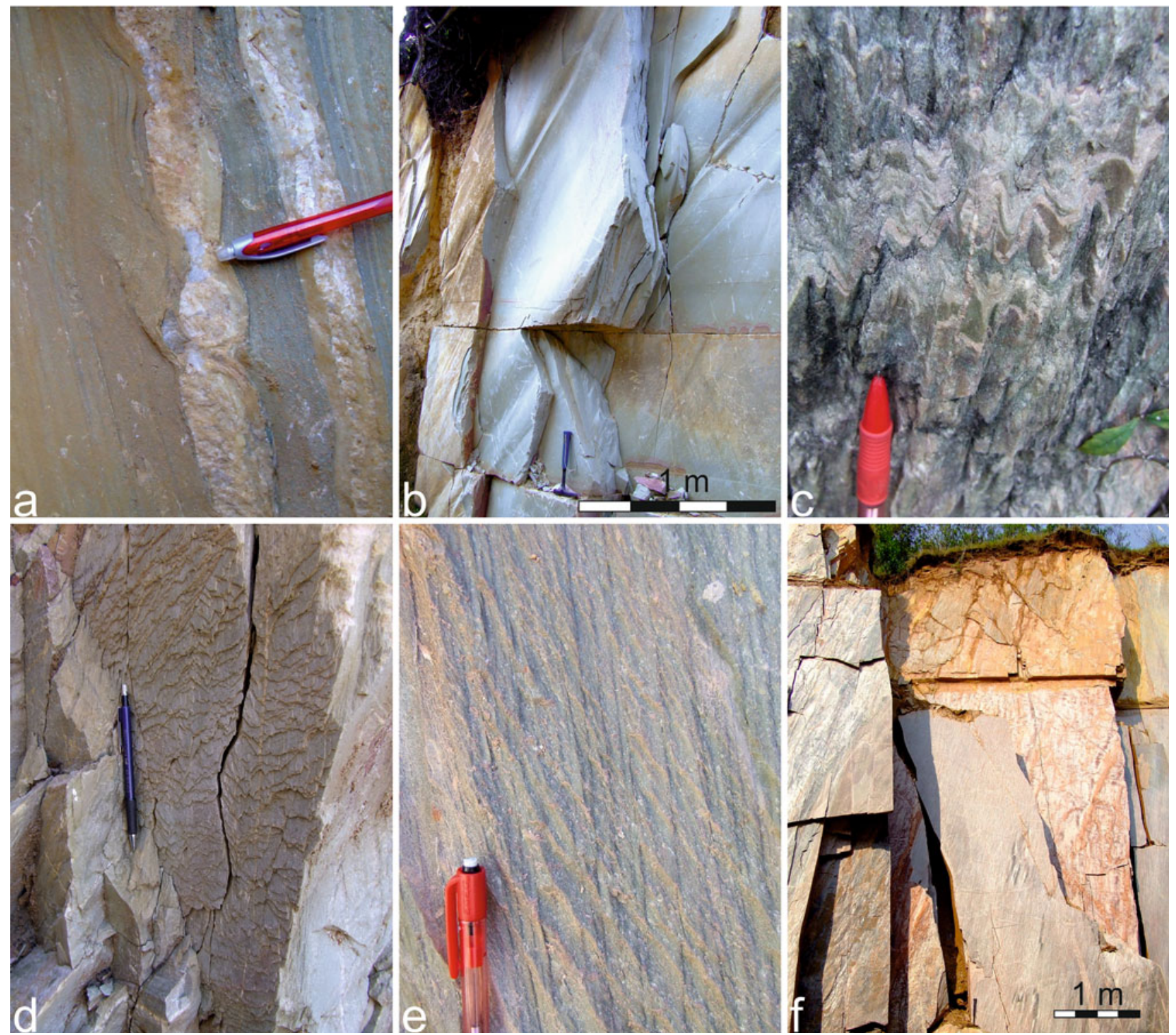

Fig. 17 Structural elements negatively affecting the dolomitic slate deposits in Uruguay. a Carbonate boudins with quartz necks. b Foliation in slate showing large amplitudes and very frequent kink bands. c Highly folded slate. d Scales develop where $S_{0-1}$ and $S_{2}$

northwest side and Piedra laja verde oscuro (U38C), which is exposed as a 7-m "layer" on the southeast side. These varieties are designated first quality $\left(\mathrm{Q}_{1}\right)$, meaning that they represent an excellent fissility and the plates obtained by splitting are very thin $(16 \mathrm{~mm})$. On both sides of the deposit varieties with inferior quality can be mined. The second quality is defined as $\mathrm{Q}_{2}$, having this variety an angle between $\mathrm{S}_{0-1}$ and $\mathrm{S}_{2}$ larger than $30^{\circ}$, and therefore, a non-completely parallel foliation and splitting in wider plates. The third quality, $\mathrm{Q}_{3}$, is a variety with bad fissility due to the occurrence of folds (kink bands) and a stepped foliation surface.

Currently the depth of the deposit is $15 \mathrm{~m}$. Considering that the foliation $\mathrm{S}_{0-1}$ dips about $80^{\circ}$ to the northwest and intersect at a low angle of $8^{\circ}$. e Main foliation indicated by pencil $\left(\mathrm{S}_{0-1}\right)$ and posterior foliation $\left(\mathrm{S}_{2}\right)$ intersecting at approximately $30^{\circ}$. f Joint systems: subhorizontal, subvertical perpendicular and parallel to the foliation

the deposit has a maximum width of $12 \mathrm{~m}$, the maximum depth to which the mining could proceed without considering the safety risks would be $50 \mathrm{~m}$. A simplified model of the impact of the foliation dip and how it would influence the mining is illustrated in Fig. 19. Others factors also influence the depth of mining. The depth of the water table plays an important role in mining since the annual rainfall in Uruguay is relatively high, about $1,200 \mathrm{~mm}$, which affects the pumping of water in a quarry at a 50-m depth.

The rate of exploitation of marketable products with a quality level $\mathrm{Q}_{1}$ is relatively low in comparison to other dimensional stone deposits. The current yield of $7 \%$ in dolomitic slates, based on international comparable 

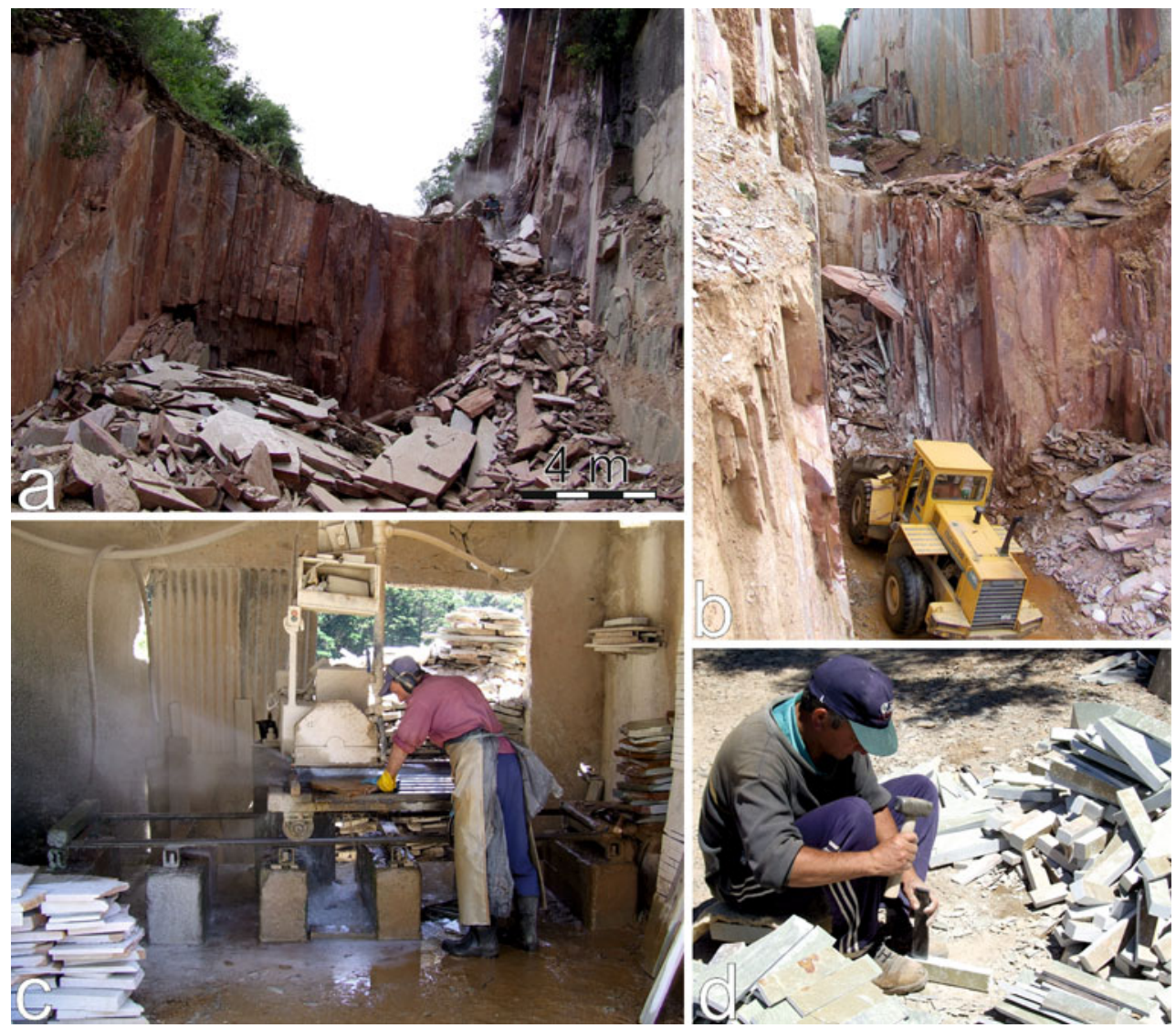

Fig. 18 Mining activities in a typical dolomitic slate quarry in the Arroyo Minas Viejas district (AMVD) in Uruguay (Company Carmine Rufo). a Active slate quarry where Piedra laja ocre (U38A) is mined. b Active slate quarry where Piedra laja gris plomo

deposits and the mining efficiency according to the local producers, could be considerably improved by the commercialization of the $\mathrm{Q}_{2}$ and $\mathrm{Q}_{3}$ varieties.

For the calculation of the reserve in the southern section of the deposit (G119) a length of 200, a width of 12 and a depth of $20 \mathrm{~m}$ are considered. From a total volume of $48,000 \mathrm{~m}^{3}$ a yield of $7 \%$ is expected. Therefore, the dolomitic slate reserves in quarry G119 would be $3,360 \mathrm{~m}^{3}$. For the northern section of the deposit (G118) the length considered is $100 \mathrm{~m}$, the width and depth remain the same as in the southern section. Considering the yield of $7 \%$ again, the estimated reserves for this section are $1,680 \mathrm{~m}^{3}$. Taking into account that the material extracted will be split into slabs of $16 \mathrm{~mm}$ thickness, a production of $315,000 \mathrm{~m}^{2}$ could be expected from this deposit.

For a mining depth of $50 \mathrm{~m}$ the total production of the deposit would be $12,600 \mathrm{~m}^{3}$ or $787,500 \mathrm{~m}^{2}$ (for 16-mm-thick slabs) considering a yield of $7 \%$. Due to the instability of the northwest wall, a large amount of waste material has to be extracted in order to reach a depth of $50 \mathrm{~m}$. Around $66,150 \mathrm{~m}^{3}$ have to be extracted, so that around $15 \%$ of this material could
(U38B) and verde clara (U38C) are mined. c Sawing of selected material to standard sizes. d Manual splitting of small tiles for wall cladding

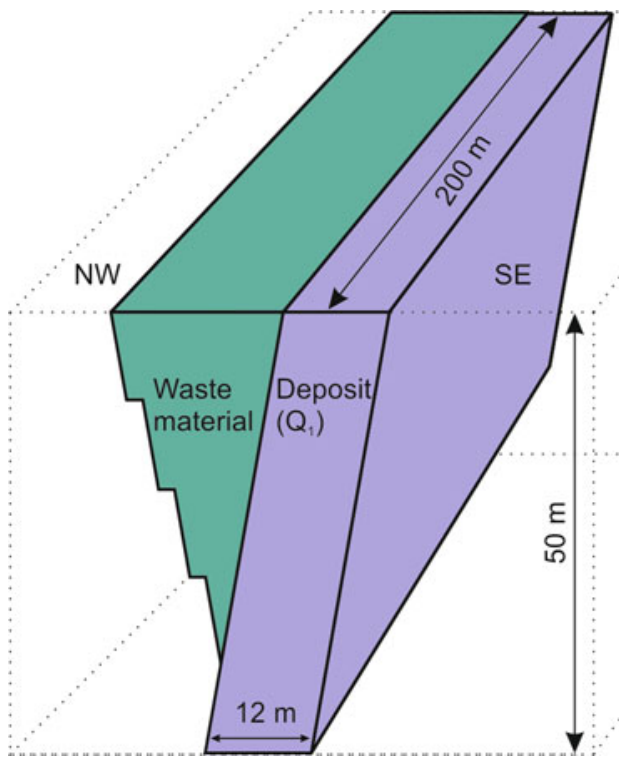

Fig. 19 Idealized model of a slate deposit with waste material to be extracted 
be commercialized as second and third quality slate $\left(\mathrm{Q}_{2}\right.$ and $\mathrm{Q}_{3}$ ) for use as rubble stone and stone stairs. This would make an additional production of $9,920 \mathrm{~m}^{3}$.

According to DINAMIGE (2012), the total production of slates in the year 2007 was $2,073 \mathrm{~m}^{3}$ consisting of the black and colored slate varieties, where the volume production of both varieties are equal. When considering a slab thickness of $16 \mathrm{~mm}$ again, the production of colored slates is almost $75,000 \mathrm{~m}^{2}$. Around $60 \%$ of the annual colored slate production presumably comes from the deposit described and analyzed above. The mining of this deposit produces $45,000 \mathrm{~m}^{2}$ annually and when the mining only goes to a depth of $20 \mathrm{~m}$, the life of the quarry would be 7 years. Using a depth of $50 \mathrm{~m}$ would allow the deposit to be active for a period of 17 years and 6 months.

To increase the $7 \%$ yield, the raw material should be reassessed in order to transform it into a marketable product. The raw material is defined as quality $\mathrm{Q}_{2}$ and $\mathrm{Q}_{3}$. The alternative uses for $\mathrm{Q}_{2}$ and $\mathrm{Q}_{3}$ are rubble stones, stone stair treads, thick polygonal slabs and irregular material for gardens (e.g., as stepping stones) and landscaping stones. The raw material that is intensively jointed, and therefore, small in size can be commercialized as tiles for indoor or outdoor cladding. Intensively folded material can also be applied as stone block steps. All these products can be sold on the local, regional (Latin America) and international markets. Other alternative uses for the local market are those which utilize the waste material resulting from the sawing. These small pieces can be reselected for the design of mosaics, for example, or be used as raw material for road construction or maintenance. For the local situation in Uruguay this has no relevancy, but the dolomitic slates show little impact to freeze-thaw and could be used without any problems in countries with colder climates.
The external factors that influence the mining costs are mainly energy (fuel), purchase of machinery, pumping of water (at $30 \mathrm{~m}$ depth), salaries, cost for mining preparation and organization, environmental costs and royalty (government taxes). Credit costs are also considered in the economic costs as they are of fundamental importance for the initial investments.

Acknowledgments We would like to thank Dipl.-Ing. Peter Machner, Dr. Axel Wetzel and Matthias Gehrke for the abrasion measurements in the laboratories of the AMPA (Amtliche Materialprüfanstalt für das Bauwesen) of the University of Kassel, Dr. Rudolf Naumann for the geochemical measurement in GFZ (GeoForschungsZentrum) in Potsdam, Dr. Wolfgang Wagner, Dr. Dieter Jung and Andreas Jäger for their support and the permission to use the software Slatenorm for the plotting of geochemical data and Dipl.Min. Dirk Kirchner for the freeze resistant tests. In Uruguay thanks to the Rufo family which allowed us the study of their quarries and facilitated us samples. To Dr. Miguel Basei, Dr. Axel Vollbrecht, Harald Tonn, Dr, Michael Huppert, Dr. Cornelius Fischer, Dr. Klaus Wemmer, Dipl. Geol. Frithjof Bense, Dipl. Geol. Stefan Löbens and Günter Tondock we are very grateful for their help in the collection or preparation of samples and for the fructiferous discussions. Special thanks also go to the students and friends for their help. P. Oyhantçabal thanks the support of the Deutscher Akadamischer Austausch Dienst (DAAD research grant A/12/04666) and the Universidad de la República of Uruguay. M. Morales Demarco is grateful to DAAD long-term fellowship (A/07/98548).

Open Access This article is distributed under the terms of the Creative Commons Attribution License which permits any use, distribution, and reproduction in any medium, provided the original author(s) and the source are credited.

\section{Appendix}

See Appendix Tables 10, 11, 12.

Table 10 Major element geochemistry of the investigated slates

\begin{tabular}{llllllllllllll}
\hline Sample & $\mathrm{SiO}_{2}$ & $\mathrm{TiO}_{2}$ & $\mathrm{Al}_{2} \mathrm{O}_{3}$ & $\mathrm{Fe}_{2} \mathrm{O}_{3}$ & $\mathrm{MnO}$ & $\mathrm{MgO}$ & $\mathrm{CaO}$ & $\mathrm{Na}_{2} \mathrm{O}$ & $\mathrm{K}_{2} \mathrm{O}$ & $\mathrm{P}_{2} \mathrm{O}_{5}$ & $\mathrm{H}_{2} \mathrm{O}$ & $\mathrm{CO}_{2}$ & $\mathrm{Sum}^{2}$ \\
\hline U33 & 42.64 & 0.405 & 9.58 & 3.51 & 0.06 & 9.81 & 11.12 & $<0.01$ & 3.21 & 0.094 & 2.15 & 16.91 & 99.49 \\
U45 & 50.9 & 0.410 & 10.2 & 3.38 & 0.08 & 8.52 & 8.42 & 0.88 & 2.24 & 0.130 & 2.25 & 12.39 & 99.76 \\
U38D & 30.45 & 0.244 & 6.49 & 1.9 & 0.06 & 12.8 & 17.23 & $<0.01$ & 2.04 & 0.065 & 1.61 & 26.92 & 99.81 \\
U38C & 31.22 & 0.235 & 6.07 & 2.58 & 0.08 & 12.49 & 17.16 & $<0.01$ & 1.84 & 0.068 & 1.48 & 26.68 & 99.90 \\
U38B & 42.48 & 0.324 & 8.64 & 4.08 & 0.06 & 9.1 & 11.88 & $<0.01$ & 2.88 & 0.088 & 1.79 & 18.41 & 99.74 \\
U38A & 37.44 & 0.321 & 7.82 & 2.52 & 0.09 & 10.43 & 14.54 & $<0.01$ & 2.69 & 0.082 & 1.45 & 22.43 & 99.81 \\
U38M & 32.42 & 0.258 & 6.81 & 2.23 & 0.05 & 12.38 & 16.25 & $<0.01$ & 2.09 & 0.065 & 1.6 & 25.38 & 99.54 \\
UY-19 & 30.56 & 0.237 & 6.14 & 2.95 & 0.09 & 12.84 & 17.12 & $<0.01$ & 1.83 & 0.07 & 1.58 & 26.45 & 99.87 \\
UY-21 & 29.15 & 0.23 & 6.2 & 3.32 & 0.09 & 12.24 & 17.66 & $<0.01$ & 2.14 & 0.071 & 1.25 & 27.5 & 99.85 \\
UY-45 & 43.55 & 0.373 & 8.47 & 2.03 & 0.05 & 10.82 & 11.84 & $<0.01$ & 2.35 & 0.127 & 2.14 & 18.04 & 99.79 \\
UY-54 & 34.13 & 0.276 & 6.92 & 2.74 & 0.10 & 11.26 & 16.15 & $<0.01$ & 2.36 & 0.083 & 1.38 & 24.48 & 99.87 \\
UY-85 & 40.62 & 0.271 & 6.25 & 3.44 & 0.44 & 8.28 & 14.96 & $<0.01$ & 2.36 & 0.144 & 1.37 & 21.54 & 99.68 \\
UY-87 & 33.43 & 0.271 & 6.56 & 2.93 & 0.09 & 11.27 & 16.16 & $<0.01$ & 2.33 & 0.074 & 1.4 & 25.41 & 99.92 \\
UY-88 & 37.33 & 0.299 & 6.79 & 3.27 & 0.11 & 11.59 & 14.15 & $<0.01$ & 1.84 & 0.1 & 1.9 & 21.94 & 99.32 \\
UY-90 & 30.03 & 0.236 & 6.12 & 2.54 & 0.08 & 12.27 & 17.58 & $<0.01$ & 1.97 & 0.074 & 1.27 & 27.69 & 99.86 \\
\hline
\end{tabular}


Table 10 continued

\begin{tabular}{lccccccccccccc}
\hline Sample & $\mathrm{SiO}_{2}$ & $\mathrm{TiO}_{2}$ & $\mathrm{Al}_{2} \mathrm{O}_{3}$ & $\mathrm{Fe}_{2} \mathrm{O}_{3}$ & $\mathrm{MnO}$ & $\mathrm{MgO}$ & $\mathrm{CaO}$ & $\mathrm{Na}_{2} \mathrm{O}$ & $\mathrm{K}_{2} \mathrm{O}$ & $\mathrm{P}_{2} \mathrm{O}_{5}$ & $\mathrm{H}_{2} \mathrm{O}$ & $\mathrm{CO}_{2}$ & $\mathrm{Sum}^{2}$ \\
\hline $\mathrm{UY}-106$ & 56.27 & 0.953 & 12.56 & 6.52 & 0.11 & 6.11 & 4.09 & $<0.01$ & 3.73 & 0.147 & 3.42 & 5.9 & 99.81 \\
UY-108 & 60.92 & 0.548 & 17.22 & 4.78 & 0.09 & 1.57 & 1.44 & 1.9 & 4.64 & 0.139 & 2.24 & 4.11 & 99.60 \\
AP & 60.24 & 0.754 & 15.37 & 5.39 & 0.29 & 1.95 & 3.87 & 2.24 & 3.4 & 0.211 & 2.78 & 3.2 & 99.70 \\
AR & 61.31 & 0.742 & 17.53 & 7.43 & 0.17 & 2.51 & 0.39 & 1.37 & 4.26 & 0.117 & 3.24 & 0.53 & 99.60 \\
PL & 49.91 & 1.007 & 24.49 & 10.21 & 0.08 & 2.4 & 0.24 & 0.75 & 3.16 & 0.179 & 5.46 & 1.22 & 99.10 \\
GA & 62.55 & 0.825 & 17.28 & 6.5 & 0.09 & 2.13 & 0.74 & 1.95 & 4 & 0.161 & 3.27 & 0.19 & 99.69 \\
WS & 56.43 & 0.912 & 18.58 & 7.63 & 0.14 & 2.86 & 0.87 & 0.89 & 3.48 & 0.136 & 4.4 & 2.69 & 99.02 \\
120 & 57.83 & 1.009 & 18.92 & 7.75 & 0.08 & 2.47 & 0.62 & 1.52 & 3.41 & 0.192 & 4.04 & 1.59 & 99.43 \\
150 & 57.71 & 1.016 & 18.95 & 7.46 & 0.08 & 2.38 & 0.57 & 1.53 & 3.46 & 0.191 & 4.49 & 1.61 & 99.44 \\
PO & 66.93 & 0.753 & 14.61 & 4.6 & 0.05 & 2.12 & 1.33 & 2.52 & 3.42 & 0.14 & 2.12 & 0.83 & 99.42 \\
LO & 71.07 & 0.581 & 10.86 & 3.34 & 0.08 & 1.18 & 3.5 & 1.25 & 2.79 & 0.132 & 1.82 & 3 & 99.60 \\
\hline
\end{tabular}

Table 11 Trace element geochemistry of the investigated slates

\begin{tabular}{|c|c|c|c|c|c|c|c|c|c|c|c|}
\hline Sample & $\mathrm{Ba}$ & $\mathrm{Cr}$ & $\mathrm{Ga}$ & $\mathrm{Nb}$ & $\mathrm{Ni}$ & $\mathrm{Rb}$ & $\mathrm{Sr}$ & V & $\mathrm{Y}$ & $\mathrm{Zn}$ & $\mathrm{Zr}$ \\
\hline U33 & 486 & 66 & 13 & 13 & 43 & 106 & 61 & 36 & 20 & 26 & 130 \\
\hline U45 & 313 & 64 & 14 & 11 & 26 & 85 & 45 & 49 & 18 & 58 & 115 \\
\hline U38D & 299 & 43 & 10 & $<10$ & 24 & 72 & 78 & 32 & 17 & 16 & 63 \\
\hline $\mathrm{U} 38 \mathrm{C}$ & 414 & 41 & $<10$ & $<10$ & 29 & 71 & 90 & 22 & 18 & 18 & 56 \\
\hline U38B & 1,009 & 47 & 10 & 10 & 35 & 119 & 73 & 43 & 19 & 16 & 77 \\
\hline U38A & 728 & 49 & $<10$ & 11 & 34 & 95 & 55 & 37 & 17 & 13 & 99 \\
\hline $\mathrm{U} 38 \mathrm{M}$ & 343 & 45 & $<10$ & $<10$ & 41 & 76 & 80 & 34 & 19 & 20 & 63 \\
\hline UY-19 & 675 & 44 & $<10$ & $<10$ & 39 & 73 & 93 & 29 & 18 & 24 & 54 \\
\hline UY-21 & 659 & 39 & $<10$ & $<10$ & 36 & 88 & 91 & 31 & 19 & 19 & 56 \\
\hline UY-45 & 456 & 57 & 11 & 12 & 56 & 90 & 80 & 35 & 14 & 33 & 82 \\
\hline UY-54 & 556 & 50 & $<10$ & 10 & 36 & 83 & 58 & 35 & 19 & 12 & 70 \\
\hline UY-85 & 315 & 39 & $<10$ & 10 & 22 & 97 & 120 & 16 & 40 & 12 & 83 \\
\hline UY-87 & 477 & 48 & $<10$ & 11 & 37 & 82 & 85 & 29 & 18 & 14 & 77 \\
\hline UY-88 & 3,204 & 49 & $<10$ & 12 & 42 & 69 & 197 & 35 & 19 & 42 & 72 \\
\hline UY-90 & 451 & 48 & $<10$ & 10 & 41 & 77 & 105 & 30 & 20 & 20 & 58 \\
\hline UY-106 & 443 & 94 & 14 & 22 & 54 & 145 & 70 & 78 & 18 & 67 & 128 \\
\hline UY-108 & 719 & 57 & 22 & 18 & 37 & 232 & 137 & 70 & 30 & 57 & 166 \\
\hline $\mathrm{AP}$ & 598 & 70 & 23 & 18 & 56 & 174 & 138 & 85 & 44 & 86 & 232 \\
\hline $\mathrm{AR}$ & 591 & 74 & 25 & 19 & 49 & 212 & 79 & 103 & 38 & 100 & 139 \\
\hline PL & 536 & 135 & 31 & 20 & 85 & 158 & 177 & 169 & 39 & 169 & 99 \\
\hline GA & 727 & 88 & 22 & 20 & 50 & 211 & 130 & 99 & 41 & 100 & 212 \\
\hline WS & 440 & 147 & 25 & 19 & 96 & 167 & 110 & 130 & 34 & 101 & 180 \\
\hline 120 & 691 & 104 & 25 & 21 & 56 & 144 & 140 & 122 & 42 & 106 & 232 \\
\hline 150 & 711 & 106 & 24 & 22 & 56 & 149 & 139 & 135 & 41 & 102 & 223 \\
\hline $\mathrm{PO}$ & 769 & 66 & 19 & 18 & 38 & 144 & 225 & 76 & 37 & 67 & 277 \\
\hline LO & 543 & 44 & 15 & 17 & 28 & 121 & 263 & 40 & 38 & 46 & 408 \\
\hline
\end{tabular}


Table 12 Normative minerals calculated using Slatenorm.exe

\begin{tabular}{|c|c|c|c|c|c|c|c|c|c|c|}
\hline Sample & $\mathrm{qz}$ & $\mathrm{mu}$ & pa & or & $a b$ & an & fac & mac & $\mathrm{mc}$ & \\
\hline U33 & 26.42 & 24.07 & 0.00 & 2.32 & 0.00 & 0.00 & 0.00 & 0.00 & 6.17 & \\
\hline U45 & 32.43 & 19.03 & 5.38 & 0.00 & 3.79 & 0.00 & 0.00 & 0.00 & 7.90 & \\
\hline U38A & 25.75 & 19.29 & 0.00 & 2.51 & 0.00 & 0.00 & 0.00 & 0.00 & 0.90 & \\
\hline U38B & 28.65 & 21.79 & 0.00 & 1.96 & 0.00 & 0.00 & 0.00 & 0.00 & 2.70 & \\
\hline $\mathrm{U} 38 \mathrm{C}$ & 22.48 & 15.69 & 0.00 & 0.00 & 0.00 & 0.00 & 0.21 & 0.09 & 1.51 & \\
\hline U38D & 21.13 & 16.90 & 0.00 & 0.37 & 0.00 & 0.00 & 0.00 & 0.00 & 2.02 & \\
\hline U38M & 22.73 & 17.84 & 0.00 & 0.00 & 0.00 & 0.00 & 0.04 & 0.03 & 2.20 & \\
\hline UY-19 & 21.36 & 15.55 & 0.00 & 0.00 & 0.00 & 0.00 & 0.38 & 0.23 & 2.17 & \\
\hline UY-21 & 19.64 & 15.26 & 0.00 & 2.06 & 0.00 & 0.00 & 0.00 & 0.00 & -0.36 & \\
\hline UY-45 & 31.22 & 19.97 & 0.00 & 0.00 & 0.00 & 0.00 & 0.67 & 1.76 & 5.27 & \\
\hline UY-54 & 23.39 & 17.13 & 0.00 & 2.04 & 0.00 & 0.00 & 0.00 & 0.00 & 1.19 & \\
\hline UY-85 & 30.76 & 14.59 & 0.00 & 3.90 & 0.00 & 0.00 & 0.00 & 0.00 & -1.62 & \\
\hline UY-87 & 23.61 & 15.89 & 0.00 & 2.77 & 0.00 & 0.00 & 0.00 & 0.00 & -0.65 & \\
\hline UY-88 & 27.57 & 15.73 & 0.00 & 0.00 & 0.00 & 0.00 & 1.29 & 1.20 & 3.14 & \\
\hline UY-90 & 21.79 & 15.69 & 0.00 & 0.76 & 0.00 & 0.00 & 0.00 & 0.00 & -0.69 & \\
\hline $\begin{array}{l}\text { UY- } \\
106\end{array}$ & 36.01 & 31.82 & 0.00 & 0.00 & 0.00 & 0.00 & 0.68 & 0.68 & 7.73 & \\
\hline $\begin{array}{l}\text { UY- } \\
108\end{array}$ & 31.58 & 35.89 & 0.00 & 2.69 & 16.28 & 0.00 & 0.00 & 0.00 & 1.55 & \\
\hline AP & 29.59 & 29.17 & 0.51 & 0.00 & 18.87 & 1.41 & 0.00 & 0.00 & 4.53 & \\
\hline GA & 30.22 & 34.23 & 0.81 & 0.00 & 16.14 & 2.40 & 0.00 & 0.00 & 4.94 & \\
\hline $\mathrm{AR}$ & 31.08 & 36.43 & 4.22 & 0.00 & 8.82 & 0.91 & 0.00 & 0.00 & 5.82 & \\
\hline PL & 28.16 & 27.62 & 9.56 & 0.00 & 0.00 & 0.00 & 13.60 & 8.57 & 0.00 & \\
\hline WS & 33.79 & 30.44 & 11.35 & 0.00 & 0.00 & 0.00 & 5.61 & 3.59 & 3.74 & \\
\hline 120 & 30.37 & 29.58 & 18.96 & 0.00 & 0.19 & 1.17 & 0.00 & 0.00 & 5.81 & \\
\hline 150 & 30.39 & 30.17 & 18.47 & 0.00 & 0.68 & 1.18 & 0.00 & 0.00 & 5.62 & \\
\hline $\mathrm{PO}$ & 33.38 & 18.95 & 0.00 & 7.30 & 21.68 & 5.52 & 0.00 & 0.00 & 4.94 & \\
\hline LO & 50.55 & 20.76 & 0.00 & 2.20 & 10.72 & 1.49 & 0.00 & 0.00 & 2.74 & \\
\hline $\mathrm{TH}^{*}$ & 35.24 & 33.31 & 13.70 & 0.00 & 0.00 & 0.34 & 2.00 & 0.81 & 3.40 & \\
\hline Sample & $\mathrm{fc}$ & ct & $\mathrm{cc}$ & dol & sid & $\mathrm{pt}$ & gr & ilm & ap & sum \\
\hline U33 & 4.73 & 0.00 & 1.92 & 32.97 & 0.00 & 0.23 & 0.18 & 0.79 & 0.21 & 100 \\
\hline U45 & 4.73 & 0.00 & 2.10 & 23.39 & 0.00 & 0.04 & 0.12 & 0.78 & 0.30 & 100 \\
\hline U38A & 3.60 & 0.00 & 0.84 & 46.21 & 0.00 & 0.00 & 0.10 & 0.61 & 0.19 & 100 \\
\hline U38B & 6.00 & 0.00 & 1.31 & 36.65 & 0.00 & 0.00 & 0.11 & 0.61 & 0.21 & 100 \\
\hline U38C & 3.65 & 0.00 & 1.14 & 54.48 & 0.00 & 0.00 & 0.12 & 0.46 & 0.16 & 100 \\
\hline U38D & 2.67 & 0.00 & 0.98 & 55.13 & 0.00 & 0.04 & 0.12 & 0.46 & 0.16 & 100 \\
\hline U38M & 2.96 & 0.00 & 0.48 & 52.76 & 0.00 & 0.19 & 0.11 & 0.50 & 0.16 & 100 \\
\hline UY-19 & 3.87 & 0.00 & 1.02 & 54.40 & 0.00 & 0.23 & 0.17 & 0.46 & 0.16 & 100 \\
\hline UY-21 & 4.95 & 0.00 & 0.58 & 57.05 & 0.00 & 0.04 & 0.18 & 0.44 & 0.16 & 100 \\
\hline UY-45 & 2.20 & 0.00 & 0.90 & 36.89 & 0.00 & 0.00 & 0.12 & 0.71 & 0.30 & 100 \\
\hline UY-54 & 4.02 & 0.00 & 1.97 & 49.37 & 0.00 & 0.00 & 0.16 & 0.53 & 0.19 & 100 \\
\hline UY-85 & 5.76 & 0.00 & 4.12 & 41.52 & 0.00 & 0.00 & 0.14 & 0.52 & 0.33 & 100 \\
\hline UY-87 & 4.20 & 0.00 & 0.00 & 53.22 & 0.08 & 0.04 & 0.16 & 0.52 & 0.16 & 100 \\
\hline UY-88 & 3.72 & 0.00 & 0.47 & 45.75 & 0.00 & 0.19 & 0.14 & 0.58 & 0.23 & 100 \\
\hline UY-90 & 3.57 & 0.00 & 0.00 & 57.92 & 0.16 & 0.00 & 0.18 & 0.46 & 0.16 & 100 \\
\hline UY-106 & 8.43 & 0.00 & 0.57 & 11.86 & 0.00 & 0.00 & 0.04 & 1.82 & 0.35 & 100 \\
\hline UY-108 & 0.79 & 0.00 & 0.00 & 4.18 & 5.62 & 0.00 & 0.03 & 1.06 & 0.33 & 100 \\
\hline $\mathrm{AP}$ & 7.80 & 0.00 & 6.00 & 0.00 & 0.00 & 0.02 & 0.16 & 1.44 & 0.49 & 100 \\
\hline
\end{tabular}


Table 12 continued

\begin{tabular}{lrlllllllll}
\hline Sample & fc & ct & cc & dol & sid & pt & gr & ilm & ap \\
\hline GA & 9.05 & 0.00 & 0.09 & 0.00 & 0.00 & 0.02 & 0.13 & 1.60 & 0.38 \\
AR & 10.67 & 0.00 & 0.09 & 0.00 & 0.00 & 0.13 & 0.11 & 1.42 & 0.28 \\
PL & 0.00 & 9.12 & 0.00 & 0.01 & 0.10 & 0.44 & 0.40 & 1.98 & 0.43 & 100 \\
WS & 6.38 & 0.00 & 0.56 & 1.31 & 0.00 & 0.58 & 0.53 & 1.79 & 0.34 & 100 \\
120 & 10.73 & 0.00 & 0.26 & 0.00 & 0.00 & 0.13 & 0.39 & 1.97 & 0.45 \\
150 & 10.29 & 0.00 & 0.16 & 0.00 & 0.00 & 0.15 & 0.43 & 2.00 & 0.45 \\
PO & 5.95 & 0.00 & 0.09 & 0.00 & 0.00 & 0.21 & 0.20 & 1.45 & 0.33 \\
LO & 4.41 & 0.00 & 5.48 & 0.00 & 0.00 & 0.08 & 0.15 & 1.12 & 0.31 \\
TH* & 9.23 & 0.00 & 0.00 & 0.00 & 0.00 & 0.00 & 0.00 & 1.73 & 0.23 \\
\hline
\end{tabular}

Data from Theuma Fruchtschiefer ( $\left.\mathrm{TH}^{*}\right)$ after Fischer et al. (2011)

$a b$ albite, an anorthite, $a p$ apatite, $c c$ calcite, $c t$ chloritoid, $d o l$ dolomite, $f a c$ daphnite, $f c$ greenalite, $g r$ graphite, $i l m$ ilmenite, $m a c$ amesite, $m c$ serpentine, $т и$ muscovite, or orthoclase, $p a$ paragonite, $p t$ pyrite, $q z$ quartz, sid siderite

\section{References}

Allaby A, Allaby M (1990) The concise Oxford dictionary of earth sciences. Oxford University Press, Oxford

Basei MAS, Siga O Jr, Masquelin H, Harara OMM, Reis Neto JM, Preciozzi F (2000) The Dom Feliciano Belt of Brazil and Uruguay and its Foreland Domain the Rio de la Plata Craton: framework, tectonic evolution and correlation with similar provinces of Southwestern Africa. In: Cordani UG, Milani EJ, Thomaz Filho A, Campos DA (eds) Tectonic evolution of South America, Rio de Janeiro, pp 311-334

Basei MAS, Frimmel HE, Nutman AP, Preciozzi F (2008) West Gondwana amalgamation based on detrital zircon ages from Neoproterozoic Ribeira and Dom Feliciano belts of South America and comparison with coeval sequences from SW Africa. In: Pankhurst RJ, Trouw RAJ, de Brito Neves BB, De Wit MJ (eds) West Gondwana: Pre-Cenozoic correlations across the South Atlantic Region, vol 294. Geological Society, Special Publications, London, pp 239-256

Bentz A, Martini HJ (1968) Lehrbuch der Angewandten Geologie, Band 2, 1: Methoden zur Erforschung der Lagerstätten von Erzen, Kohle, Erdöl, Slazen, Industrie-Mineralen und Steinen und Erden. Sttutgart (Enke)

Bossi J, Campal N (1992) Magmatismo y tectónica transcurrente durante el Paleozoico Inferior en Uruguay. In: Gutierrez Marco JC, Saavedra J, Rabano I (eds) Paleozoico Inferior de Iberoamérica. Universidad de Extremadura, España, pp 345-356

Bossi J, Ferrando L (2001) Carta Geológica del Uruguay a escala 1/500 000, v. 2.0, versión digital. Ed. Cátedra de Geología, Facultad de Agronomía, Montevideo

Bossi J, Fernández A, Elizalde G (1965) Predevoniano en el Uruguay

Brito Neves BB, Cordani U (1991) Tectonic evolution of South America during the Late Proterozoic. Precambrian Res 53:23-40

Bucher K, Frey M (2002) Petrogenesis of metamorphic rocks, 7th edn. Springer, New York

Canavan F (1973) Notes on the terms 'stratiform', 'stratabound' and 'stratigraphic control' as applied to mineral deposits. J Geol Soc Aust 19(4):543-546

Card N (2010) Colour, cups and tiles-recent discoveries at the Ness of Brodgar. Past-The Newsletter of the prehistoric society, no 66, London

Comunità Economica Europea-Uruguay. Piedras Ornamentales del Uruguay. La Cartotecnica, Rovereto
Coronel N, Spoturno J, Gómez C, Heinzen W, Mari C, Roth W, Theune C, Stampe W (1987) Carta de los recursos Minerales no matalíferos del Uruguay. DINAMIGE, Montevideo, Uruguay

de Almeida FFM (1971) Geochronological division of the Precambrian of the South America. Rev Bras Geol 1(1):13-21 San Paulo, Brasil

DIN 52108 (1988) Prüfung anorganischer nichtmetallischer Werkstoffe; Verschleißprüfung mit der Schleifscheibe nach Böhme. Beuth, Berlin

DIN EN 12372 (1999) Prüfverfahren für Naturstein-Bestimmung der Biegefestigkeit unter Mittellinienlast. Beuth, Berlin

DIN EN 1926 (1999) Prüfverfahren für Naturstein-Bestimmung der Druckfestigkeit. Beuth, Berlin

DIN EN 12326-2 (2000) Schiefer und andere Natursteinprodukte für überlappende Dachdeckungen und Außenwandbekleidungen. Teil 2: Prüfverfahren. DIN Deutsches Institut für Normung e.V., Beuth, Berlin

DIN EN 13775 (2001) Prüfverfahren für Naturstein-Bestimmung der Wasseraufnahme bei atmosphärischem Druck. Beuth, Berlin

DIN EN 12326-1 (2004) Schiefer und andere Natursteinprodukte für überlappende Dachdeckungen und Außenwandbekleidungen. Teil 1: Produktspezifikation. DIN Deutsches Institut für Normung e.V., Beuth, Berlin

DINAMIGE (Dirección Nacional de Mineríaa y Geología) (2012) http://www.dinamige.gub.uy. Last accessed March 2012

Fei Y (1995) Thermal expansion. In: Ahrens T (ed) Mineral physics crystallographic: a handbook of physical constants. American Geophysical Union Books Board, Washington DC

Fischer C, Kaufhold S, Wedekind W, Dohrmann R, Karius V, Siegesmund S (2011) Weathering of Fruchtschiefer building stones: mineral dissolution or rock disaggregation? Environ Earth Sci 63:1665-1676. doi:10.1007/s12665-011-0986-z

Fluhr JW, Gloor M, Merkel W, Warnecke J, Höffler U, Lehmacher W, Glutsch J (1998) Antibacterial and sebosuppressive efficacy of a combination of chloramphenicol and pale sulfonated shale oil. Multicentre, randomized, vehicle-controlled, double-blind study on 91 acne patients with acne papulopustulosa (Plewig and Kligman's grade II-III). Arzneimittelforschung 48(2): 188-196

Fragoso César R (1980) O cratón do Río de la Plata e o Cinturão Dom Feliciano no Escudo Uruguaio-Sul-Riograndense. In: XXXI Congresso Brasileiro de Geología, Anais, Brasil, vol 5, pp 1879-2892 
García-Guinea J, Lombardero M, Roberts B, Taboada J, Peto A (1998) Mineralogy and microstructure of roofing slate: thermo-optical behaviour and fissility. Materiales de Construcción 48(251)

Gayko G, Cholcha W, Kietzmann M (2000) Anti-inflammatory, antibacterial and antimycotic effects of dark sulfonated shale oil (ichthammol). Berl Munch Tierarztl Wochenschr 113(10):368373

Hockmann A, Kessler DW (1950) Thermal and moisture expansion studies of some domestic granites. US Bur Stand J Res 44:395-410

Ivaldi G, Catti M, Ferraris G (1988) Crystal structure at 25 and $700{ }^{\circ} \mathrm{C}$ of magnesiochloritoid from a high-pressure assemblage (Monte Rosa). Amer Mineral 73:358-364

Jackson JA (1997) Glossary of geology (4th edn). American Geophysical Institute, Alexandria, VA

Klopfer H (1985) Feuchte. In: Lutz P, Jenisch R, Klopefer H (eds) Lehrbuch der Bauphysik. Teubner, Stuttgart

Koch A, Siegesmund S (2004) The combined effect of moisture and temperature on the anomalous behavior of marbles. Environ Geol 46(3-4):350-363

Laboratório Nacional de Energia e Geologia, Portugal. http://e-geo. ineti.pt/bds/ornabase/. Last accessed March 2012

Listemann H, Schölermann A, Meigel W (1993) Antifungal activity of sulfonated shale oils. Arzneimittelforschung 43(7):784-788

Midot D (1984) Etude géologique et diagnostique métallogénique pour $\mathrm{l}^{\prime}$ exploration du secteur Minas (Uruguay). Tesis, 3eme Cycle, Univ. P. et M. Curie, París, France, pp 1-175

Monicard RP (1980) Properties of reservoir rocks: core analysis. Edition Technip, Paris

Montani C (2008) Stone. Repertorio economico mondiale World marketing handbook Faenza Editrice. ISBN: 978-88-8138-121

Morales Demarco M, Oyhantçabal P, Stein KJ, Siegesmund S (2011) Black dimensional stones: geology, technical properties and deposit characterization of the dolerites from Uruguay. Environ Earth Sci 63(7-8):1879-1909. doi:10.1007/s12665-010-0827-5 Special Issue: Monuments under Threat: Environmental Impact, Preservation Strategies and Natural Stone Resources

Mosch S (2008) Optimierung der Exploration, Gewinnung und Materialcharakterisierung von Naturwerksteinen. Dissertation, University of Göttingen

Mosch S, Siegesmund S (2007) Statischer Verhalten petrophysikalischer und technischer Eigenschaften von Naturwerksteinen. Z dt Ges Geowiss 158(4):821-868

Natursteinwerk Theuma AG. http://www.natursteinwerk-theuma.de. Last access March 2012

Oyhantçabal P, Spoturno J, Goso E, Heimann A, Bergalli L (2001) Asociaciones litológicas en las supracrustales del grupo Lavalleja y sus intrusiones asociadas en la hoja Fuente del Puma (Sur de Minas). In: III Cong. Uruguayo de Geología y XI Cong. Latinoam. Geol. Montevideo, Uruguay. CD Abstract, 246

Oyhantçabal P, Siegesmund S, Stein KJ, Spoturno J (2007) Dimensional stones in Uruguay: situation and perspectives. Z dt Ges Geowiss 158(3):417-428
Oyhantçabal P, Siegesmund S, Wemmer K (2011) The Río de la Plata Craton: a review of units, boundaries, ages and isotopic signature. Int J Earth Sci 100(2-3):201-220. doi:10.1007/s00531-010-0580-8

Passchier CW, Trouw RAJ (1996) Microtectonics, 2nd edn. Springer, Berlin. ISBN 3-540-58713-6

Porada H (1989) Pan-African rifting and orogenesis in Southern to Equatorial Africa and Eastern Brazil. Precambrian Res 44:103-136

Preciozzi F, Masquelin H, Basei MAS (1999) The Namaqua/ Grenville Terrane of eastern Uruguay. In: II South American Symposium on Isotope Geology, Carlos Paz

Reeder RJ, Markgraf SA (1986) High-temperature crystal chemistry of dolomite. Am Mineral 71:795-804

Robertson S (1999) BGS rock classification scheme, volume 2. Classification of metamorphic rocks. British Geological Survey Research Reports, Research Report 99-02

Robie RA, Bethke PM (1966) X-ray crystallographic data, molar volumes and densities of minerals. Clark Jr SP (ed) Handbook of physical constants. Geol Soc Am, pp 58-73

Rüdrich J, Kirchner D, Siegesmund S (2011) Physical weathering of building stones induced by freeze-thaw action: a laboratory longterm study. Environ Earth Sci. 63:1573-1586. doi:10.1007/ s12665-010-0826-6

Ruiz García C (1977) Aplicaciones al microscopio en relación con la calidad de las pizarras de techar. Boletín Geológico y Minero. T. LXXXVIII-I, pp 72-77

Sánchez Bettucci L (1998) Evolución tectónica del Cinturón Dom Feliciano en la región Minas-Piriápolis, Uruguay. PhD Tesis, Facultad de Ciencias Exactas y Naturales, Universidad de Buenos Aires, pp 1-344

Sánchez Bettucci L, Ramos VA (1999) Aspectos geológicos de las rocas metavolcánicas y metasedimentarias del Grupo Lavalleja, sudeste de Uruguay. Rev Bras Geocienc 29:557-570

Sánchez Bettucci L, Peel E, Oyhantçabal P (2010) Precambrian Geotectonic units of the Río de La Plata craton. Intern Geol Rev 32(1):50-78

Shelley D (1993) Igneous and metamorphic rocks under the microscope. Chapman and Hall, London

Siegesmund S, Dürrast H (2011) Physical and mechanical properties of rocks. In: Siegesmund S, Snethlage $\mathrm{R}$ (eds) Stone in architecture: properties, durability, 4th edn. Springer, Berlin

Siegesmund S, Stein KJ (2007) 150 Jahre Schiefer aus Lotharheil: Kein Auslaufmodell. Naturstein 12:60-63

Strohmeyer D (2003) Gefügeabhängigkeit technischer Gesteinseigenschaften. Dissertation, University of Göttingen

Wagner W (2007) Grundlagen für die Prüfung von Dach- und Wandschiefern. Z dt Ges Geowiss 158(4):785-805

Ward CR, Gómez Fernández F (2003) Quantitative mineralogical analysis of Spanish roofing slates using the Rietveld method and X-ray powder diffraction data. Eur J Mineral 15(6):1051-1062

Weiss T, Siegesmund S, Kirchner D, Sippel J (2004) Insolation weathering and hygric dilatation: two competitive factors in stone degradation. Environ Geol 46:402-413 